Prepared for the U.S. Department of Energy

under Contract DE-AC05-76RL01830

\title{
Use of Polyphosphate to Decrease Uranium Leaching in Hanford 300 Area Smear Zone Sediment
}
JE Szecsody
VR Vermeul
L Zhong JS Fruchter
M Oostrom
MD Williams

September 2012

Pacific Northwest

NATIONAL LABORATORY

Proudly Operated by Battelle Since 1965 


\title{
DISCLAIMER
}

This report was prepared as an account of work sponsored by an agency of the United States Government. Neither the United States Government nor any agency thereof, nor Battelle Memorial Institute, nor any of their employees, makes any warranty, express or implied, or assumes any legal liability or responsibility for the accuracy, completeness, or usefulness of any information, apparatus, product, or process disclosed, or represents that its use would not infringe privately owned rights. Reference herein to any specific commercial product, process, or service by trade name, trademark, manufacturer, or otherwise does not necessarily constitute or imply its endorsement, recommendation, or favoring by the United States Government or any agency thereof, or Battelle Memorial Institute. The views and opinions of authors expressed herein do not necessarily state or reflect those of the United States Government or any agency thereof.

\author{
PACIFIC NORTHWEST NATIONAL LABORATORY \\ operated by \\ BATTELLE \\ for the \\ UNITED STATES DEPARTMENT OF ENERGY \\ under Contract DE-AC05-76RL01830
}

Printed in the United States of America
Available to DOE and DOE contractors from the Office of Scientific and Technical Information, P.O. Box 62, Oak Ridge, TN 37831-0062; ph: (865) 576-8401 fax: $(865) 576-5728$
email: reports $\boldsymbol{a}$ adonis.osti.gov
Available to the public from the National Technical Information Service 5301 Shawnee Rd., Alexandria, VA 22312 ph: (800) 553-NTIS (6847) email: orders/ntis.gov <http://www.ntis.gov/about/form.aspx> Online ordering: http:/www.ntis.gov


PNNL-21733

RPT-DVZ-AFRI-003

\title{
Use of Polyphosphate to Decrease Uranium Leaching in Hanford 300 Area Smear Zone Sediment
}

\author{
JE Szecsody \\ VR Vermeul \\ L Zhong \\ JS Fruchter \\ M Oostrom \\ MD Williams
}

September 2012

Prepared for

the U.S. Department of Energy

under Contract DE-AC05-76RL01830

Pacific Northwest National Laboratory

Richland, Washington 99352 



\section{Summary}

The primary objective of this study is to summarize the laboratory investigations performed to evaluate short- and long-term effects of phosphate treatment on uranium leaching from 300 Area smear zone sediments. Column studies were used to compare uranium leaching in phosphate-treated to untreated sediments over a year with multiple stop flow events to evaluate longevity of the uranium leaching rate and mass. Phosphate treatment may decrease leaching by non-uranium calcium-phosphate precipitates coating uranium surface phases, uranium adsorption to precipitates, or slow formation of uranium-phosphate precipitates. A secondary objective was to compare polyphosphate injection, polyphosphate/xanthan injection, and polyphosphate infiltration technologies that deliver phosphate to sediment.

Although phosphate treatment did not completely eliminate uranium leaching from sediment, the long-term decrease in leaching rate, leached mass, and changes in nonlabile uranium were significant compared with untreated sediment. Under idealized laboratory conditions, a wide range of phosphate treatments resulted in a significant (average 54\%) long-term (to 1 year) decrease in leached uranium mass.

A comparison of a high phosphate treatment to no treatment over a time period of $4500 \mathrm{~h}$ shows the evolution of phosphate-treated sediment from initial high efficiency to remove uranium from solution to decreased efficiency over a long period of time. The injection strategy for polyphosphate treatment of sediments that resulted in the greatest decrease in uranium leaching was to: a) maximize the no-flow phosphate-sediment reaction time before groundwater advection, b) use a high $(\sim 50 \mathrm{mM})$ phosphate concentration, and c) use xanthan with the polyphosphate solution. Some limitations of polyphosphate treatment technologies were identified, which impact field-scale applicability in different treatment zones. Because the rate at which uranium is removed from solution in the presence of phosphate precipitates is slow, the phosphate treatment will be most effective in low flow zones (i.e., smear zone where groundwater flow occurs only seasonally). Although xanthan addition (to increase solution viscosity and improve access to low-K zones) to polyphosphate showed the greatest consistent decrease in leached uranium, viscosity decreases rapidly (half-life $52 \mathrm{~h}$ ). Because the high viscosity of the solution needs to be maintained for weeks in order to have sufficient phosphate-sediment contact in a potential smear zone application, additional research is needed. The mass of phosphate precipitate needed to decrease uranium leaching is significant, although polyphosphate and polyphosphate/xanthan injections precipitated sufficient mass ( 0.18 to $\left.0.28 \mathrm{mg} \mathrm{PO}_{4} / \mathrm{g}\right)$. While polyphosphate solution infiltration resulted in significantly greater precipitate mass, further optimization of an infiltration strategy is needed to precipitate sufficient phosphate at 20-25 ft depth needed for field scale use. Given field-scale spatial/ temporal variation in uranium concentration, water flux rates, and carbonate concentration, simulations using results of this study that incorporate the variable uranium mass and flow rates expected at field scale are needed to evaluate the effectiveness of phosphate treatment and estimate groundwater leaching concentrations over time. 



\section{Acknowledgments}

This document was prepared by the Deep Vadose Zone - Applied Field Research Initiative at Pacific Northwest National Laboratory. Funding for this work was provided by the U.S. Department of Energy Richland Operations Office. The Pacific Northwest National Laboratory is operated by Battelle Memorial Institute for the U.S. Department of Energy (DOE) under Contract DE-AC05-76RL01830. 



\section{Contents}

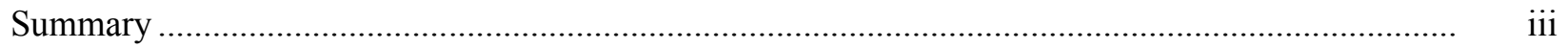

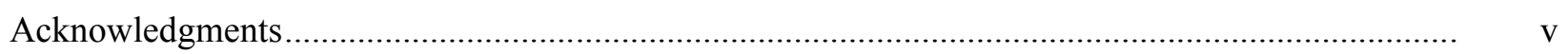

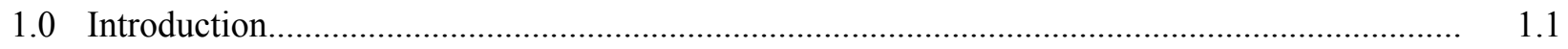

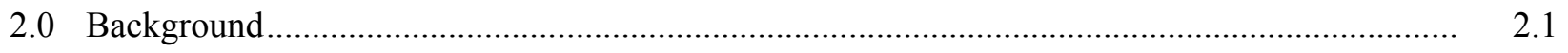

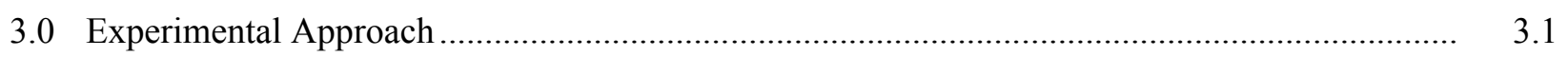

3.1 Phosphate Injection/Infiltration Experiments.............................................................. 3.1

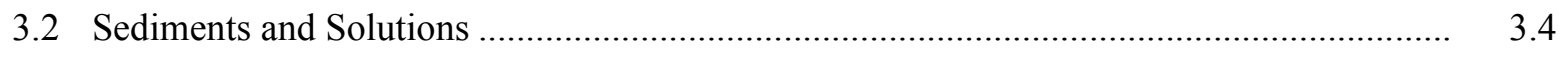

3.3 Solid and Aqueous Solution Analysis ...................................................................... 3.6

3.4 Xanthan-Phosphate System and Rheological Measurements ........................................... 3.6

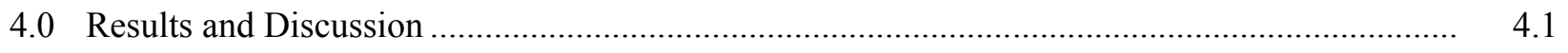

4.1 Influence of Phosphate Treatment on Uranium Leaching Mass and Rate ......................... 4.2

4.1.1 Uranium Leached Mass and Aqueous Concentrations......................................... 4.2

4.1.2 Uranium Leaching Rate............................................................................. 4.7

4.2 Influence of Phosphate/Sediment Reaction Time on Uranium Leaching ........................... 4.10

4.3 Phosphate Concentration and Uranium Leaching ............................................................ 4.11

4.4 Phosphate Delivery by Water Saturated Injection with Xanthan ...................................... 4.12

4.4.1 Xanthan Influence on Uranium Leaching ............................................................. 4.13

4.4.2 Xanthan-Phosphate Addition to Sediment: Influence on Fluid Properties ............. 4.15

4.5 Phosphate Infiltration: Phosphate Distribution and Uranium Mobility …........................ 4.19

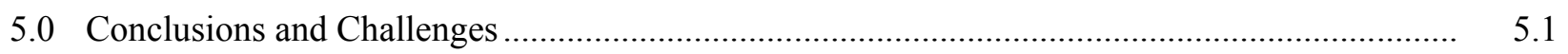

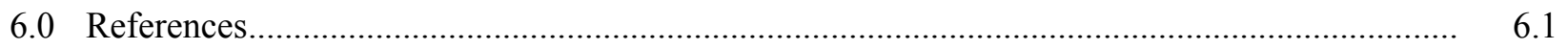

Appendix A - Influence of Water Quality on Uranium Leaching from Untreated Sediments............ A.1

Appendix B - Water-Saturated Stop Flow Column Experiments …............................................. B. 1

Appendix C - Phosphate Infiltration Experiments ................................................................... C. 1 


\section{Figures}

3.1 Uranium Adsorption at Different Uranium Concentration and Water Composition.................. 3.5

4.1 Uranium Leached Mass in Effluent for Untreated and $\mathrm{PO}_{4}$-Treated Sediments: Total Effluent Uranium and Cumulative Effluent Uranium............................................................. 4.4

4.2 Uranium Solid Phase Distribution as Defined by Sequential Liquid Extractions and Eluted Mass.....

4.3 Comparison of Uranium Leaching in $\mathrm{PO}_{4}$-Treated to Untreated Sediment with Linear or Log Uranium Concentration and Cumulative Uranium

4.4 Uranium Leaching Rates from Untreated and $\mathrm{PO}_{4}$-Treated Sediments: All Experiments, and Untreated and $\mathrm{PO}_{4}$-Treated Sediments with River Water Injection.

4.5 Influence of Sediment- $\mathrm{PO}_{4}$ Contact Time and Total Leached Uranium, or Immobile Uranium, as Defined by Uranium Extracted from Sediment by $8 \mathrm{M} \mathrm{HNO}_{3}$

4.6 Uranium Cumulative Leached Mass from Differing Phosphate Treatment and Solid Phase Distributions after Leaching

4.7 Comparison of Uranium Leaching for No Treatment and Xanthan, $\mathrm{PO}_{4}$ and $\mathrm{PO}_{4}{ }^{+}$ Xanthan, and Cumulative Uranium for Untreated and Treated .

4.8 Influence of Xanthan Gum on Calcium-Phosphate Precipitation Rate in Groundwater

4.9 Uranium Extraction Comparison of Untreated, Phosphate Treatment, and Phosphate/ Xanthan Treatment.

4.10 $\mathrm{PO}_{4}$ Influence on Xanthan Solution Rheology

4.11 Xanthan Concentration Influence on Viscosity Degradation Rate at $0.3 \mathrm{~s}^{-1}$ Shear Rate and $47 \mathrm{mM} \mathrm{PO}_{4}$, and Xanthan Viscosity Change with Increasing $\mathrm{CaCl}_{2}$ Concentration

4.12 Xanthan Viscosity Decrease in the Presence of Hanford Sediment at Differing Xanthan Concentration

4.13 Xanthan Viscosity Decrease in the Presence of Hanford Sediment Influenced by Autoclaving and Acid Washing.....

4.14 Distribution of Xanthan Solution in Sediments Injected into Sand and Hanford Sediment after 0 h, 10 days, and 14 days of Water Flushing...

4.15 Infiltration of a Large Pulse Polyphosphate Solution into a 300-cm High Column: $\mathrm{Br}$ and $\mathrm{PO}_{4}$ Breakthrough, Uranium Breakthrough, $\mathrm{H}_{2} \mathrm{O}$ Vertical Water Profile after Experiment, $\mathrm{PO}_{4}$ Vertical Profile, and Uranium Surface Phase Vertical Profile 


\section{Tables}

3.1 Description of 1-D Water-Saturated Column Experiments ….............................................. 3.2

3.2 Description of Infiltration Column Experiments ............................................................... 3.3

3.3 Composite Sediment Used in Stop Flow Experiments ......................................................... 3.4

3.4 Grain Size Distributions Used In Infiltration Columns.......................................................... 3.4

4.1 Uranium Mass Balance for Water-Saturated $\mathrm{PO}_{4}$-Treated and Untreated Column

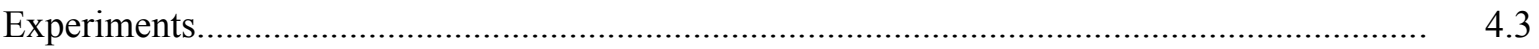

4.2 Uranium Leaching Rates from Untreated and $47 \mathrm{mM} \mathrm{PO}_{4}$-Treated Sediment........................ 4.7

4.3 Uranium Leaching Rates for Untreated and Phosphate-Treated Sediments ............................ 4.8

4.4 Uranium Adsorption to Sediment in the Presence of Xanthan .............................................. 4.14

4.5 Uranium Leaching and Phosphate Delivery in Unsaturated Columns.................................... 4.21 



\subsection{Introduction}

Uranium contamination in the Hanford Site 300 Area is primarily from the north and south process ponds. Although most contaminated sediment from the highly contaminated ponds was removed in the early 1990s, uranium continues to leach from variably saturated (i.e., smear zone) sediments beneath the original ponds seasonally and is the largest source of uranium in groundwater that eventually advects into the Columbia River (Catalano et al. 2008; Bond et al. 2008; Liu et al., 2008). The use of phosphate treatment of sediments has been shown to effectively decrease uranium leaching short-term column experiments (Shi et al. 2009) and in numerous batch and one-dimensional (1-D) column studies (Wellman et al. 2006a, 2006b, 2007, 2008a, 2008b, 2011; Bovaird et al. 2010). However, a field-scale groundwater injection of a phosphate solution in the Hanford 300 Area showed limited effectiveness at decreasing uranium concentration in fast flowing groundwater (Wellman et al. 2011; Vermeul et al. 2009). Because phosphate treatments were effective under certain conditions (including longer sediment-phosphate contact times), 1-D column studies were initiated to evaluate the long-term performance of phosphate treatment. Additional laboratory studies were initiated to evaluate the use of xanthan to increase phosphate-sediment contact time if injected in the subsurface as well as infiltration experiments to deliver phosphate to sediments above the water table. This report describes results of those experiments to evaluate limitations of polyphosphate treatment in order to determine field-scale applicability in different treatment zones. If phosphate effectiveness decreases over time, this limitation is useful at targeting specific uranium-contaminated zones (i.e., smear zone sediments that receive less advective flow compared to zones in groundwater). Methods for polyphosphate injection, polyphosphate/xanthan injection, and polyphosphate infiltration technologies that deliver phosphate to sediment were compared. Technical gaps for supporting field-scale implementation based on these phosphate treatment technologies investigated at a small to intermediate laboratory scale are identified.

These objectives were accomplished using a series of 1-D column experiments approximating field flow conditions in the Hanford 300 Area smear zone, specifically cycling groundwater (or river water) flow followed by no flow conditions. In these experiments, untreated and phosphate-treated sediments received hundreds of pore volumes of groundwater or river water flow over time periods ranging to a year, and uranium concentration, leaching rate, and mass leached were compared. Different phosphate treatments were evaluated to quantify changes in uranium leaching caused by difference in: a) phosphate concentration, $b$ ) sediment-phosphate reaction time before advective flow, and c) xanthan concentration (to increase solution viscosity). Delivery of phosphate to sediments was also evaluated in these watersaturated column studies as well as in phosphate-xanthan injection studies and large (10-ft high) phosphate infiltration columns.

Results of this experimental study provide data on the amount of decrease in uranium leaching in sediment. The comparison between untreated and phosphate-treated column results are used to characterize uranium leaching rate at multiple stop flow events, total leached uranium mass, and changes in uranium surface phases. Phosphate treatment is decreasing uranium leaching by a combination of postulated geochemical and physical processes that include uranium species adsorption onto the phosphate precipitates (Shi et al. 2009), non-uranium phosphate precipitates coating uranium surface phases, and the formation of low solubility uranyl phosphate precipitates (Wellman et al. 2008a, 2008b). 



\subsection{Background}

Uranium occurs naturally in the Hanford Site vadose zone sediments and is also present from uranium enrichment processes (surface and subsurface discharges). Uranium and plutonium enrichment processes at the Hanford Site have resulted in the release of 202,703 $\mathrm{kg}$ of uranium to the ground surface (Simpson et al. 2006) in a variety of aqueous solutions (acidic, basic, with organic complexants, and inorganic ligands $\left(\mathrm{CO}_{3}{ }^{2-}, \mathrm{PO}_{4}{ }^{3-}\right)$, which would influence the uranium migration behavior. Uranium contamination in the Hanford 300 Area was primarily associated with discharges to the north and south process ponds. Although highly contaminated sediments within ponds were removed in the early 1990s, uranium continues to leach from contaminated sediments beneath and adjacent to original ponds that are variably saturated (i.e., smear zone) sediments. Uranium in the smear zone sediments appears to be the largest source of uranium mass in groundwater that eventually advects into the Columbia River. Uranium migration in the 300 Area sediments is generally from the $21 \%$ to $76 \%$ fraction of uranium (average $\%$, Zachara et al. 2007) that is sorbed to sediments and not incorporated into minerals.

Uranium sorption to sediment is highly dependent on $\mathrm{pH}$ and carbonate concentration. At the Hanford Site, subsurface $\mathrm{pH}$ is $7.5-8.0$ in carbonate-saturated groundwater, $\mathrm{U}^{+6}$ species present are primarily $\mathrm{Ca}_{2} \mathrm{UO}_{2}\left(\mathrm{CO}_{3}\right)_{3}(\mathrm{aq}), \mathrm{CaUO}_{2}\left(\mathrm{CO}_{3}\right)_{3}{ }^{2-}$ (and to a lesser extent magnesium equivalent phases), with smaller concentrations of $\left(\mathrm{UO}_{2}\right)_{2} \mathrm{CO}_{3}(\mathrm{OH})_{3}{ }^{-}$and $\mathrm{UO}_{2}\left(\mathrm{CO}_{3}\right)_{2}{ }^{2-}$. Note also that although adsorption of uranium is assumed to be reversible, additional uranium-mineral phase interactions occur over time that more strongly retain U(VI) species. The mechanisms include stronger adsorption, precipitation, and diffusion of uranium phases into sediment micro-fractures. Therefore, specific leaching experiments are used in this study to determine the change in uranium mobility that occurs in the presence of specific waters (i.e., river or groundwater) and in the presence of phosphate precipitates.

The $\mathrm{U}(\mathrm{VI})$ sorption $\mathrm{K}_{\mathrm{d}}$ in 300 Area sediments averages $0.8 \mathrm{~mL} / \mathrm{g}$ (range 0.2 to 4.0 [Zachara et al. 2007]), with $\mathrm{K}_{d}<0.2$ for Ringold Formation gravels and $\mathrm{K}_{\mathrm{d}} 1.8$ to $4.2 \mathrm{~mL} / \mathrm{g}$ for the Ringold lower mud. The desorption $\mathrm{K}_{\mathrm{d}}$ values are higher due to sorption not being completely reversible. For 300 Area sediments, the uranium desorption $\mathrm{K}_{\mathrm{d}}$ averages $8.04 \pm 8.26(\mathrm{n}=17$ [Zachara et al. 2007]) for $<2$-mm size fraction, in groundwater. With no change in the groundwater chemistry, U(VI) sorption is fairly linear over a range of uranium concentration up to $1 \mathrm{mg} / \mathrm{L}$. The $\mathrm{U}(\mathrm{VI})$ species sorption is generally observed to be anionic (increasing sorption with lower $\mathrm{pH}$ ) in the weakly alkaline Hanford Site sediments ( $\mathrm{pH}$ 7-9), which is also representative of $\mathrm{U}(\mathrm{VI})$ species adsorption to major mineral phases (ferrihydrite, kaolinite, and quartz; Zachara et al. 2007). Aqueous carbonate concentration exerts major control on U(VI) adsorption, as most $\mathrm{Ca}-\mathrm{U}-\mathrm{CO}_{3}$ species are dominant in this mid-pH range. An increase in ionic strength greater than groundwater may lead to some U(VI) species desorption due to competition for adsorption sites. The injection of a polyphosphate solution may lead to U(VI) species desorption, although the slow precipitation of phosphates will also remove some U(VI) from aqueous solution. 



\subsection{Experimental Approach}

\subsection{Phosphate Injection/Infiltration Experiments}

Given the main objective of the laboratory experiments was to characterize the influence of phosphate solution injection on short- and long-term uranium stability in sediments, a series of 1-D water-saturated column experiments were conducted and a series of 1-D unsaturated infiltration columns were conducted. The 1-D water-saturated column experiments were conducted in steps that included:

1. phosphate solution injection at an average of 5-6 ft/day

2. time period of no flow ( $19 \mathrm{~h}$ to $4400 \mathrm{~h}$ ) approximating no flow periods in the 300 Area smear zone

3. slow groundwater (or river water) flow similar to what would occur at field scale (average rate $3.0 \mathrm{ft} /$ day). Stop flow events (100 to $1000 \mathrm{~h}$ duration) were included to evaluate uranium leaching rate.

These water-saturated column experiments were conducted varying: a) phosphate concentration, b) phosphate-sediment stop flow time before groundwater flow, and c) presence of xanthan (a high viscosity additive) with phosphate solution (or phosphate-xanthan solution) injection to evaluate differences in phosphate treatment on uranium leaching (Table 3.1). A total of 16 water-saturated column experiments were conducted, with total flow times ranging from 200 to $4400 \mathrm{~h}$, which corresponded to 53 to 450 pore volumes. Columns were packed with a composite Hanford 300 Area smear zone sediment from borehole C7117 (23-32 ft depth) that was uranium contaminated, as described in detail in the following section. Uranium leaching mass balance was established by empirical characterization of uranium surface phases (based on sequential liquid extractions) in the untreated sediment (prior to column studies), aqueous samples analyzed for aqueous uranium during flow portions of the experiments, and empirical characterization of uranium surface phases after the completion of the flow experiments. Extracted uranium surface phases included aqueous and adsorbed phases, then a series liquid extractants of increasing strength to dissolve one or more uranium minerals, which operationally define the distribution of uranium from highly leachable to much less mobile. Uranium leaching rates in groundwater or river water were calculated at stop flow events in experiments from the change in concentration before and after the stop flow and elapsed time. Phosphate mass balance was established by aqueous and solid phase extractions. For comparison to phosphate-treatments, baseline watersaturated flow experiments were conducted with river water, groundwater, and synthetic groundwater, as carbonate concentration in the water influences uranium aqueous speciation and adsorption. For some flow experiments, additional cations $\left(\mathrm{Ca}^{2+}, \mathrm{K}^{+}, \mathrm{Na}^{+}\right)$were measured on aqueous effluent samples (Table 3.1).

Stainless steel columns were packed with Hanford 300 Area sediment. The stainless steel columns were $1.72 \mathrm{~cm}$ in diameter by $20 \mathrm{~cm}$ in length, and packed with $\sim 60 \mathrm{~g}$ of sediment. The average porosity was $0.386 \pm 0.049$ and average bulk density $1.52 \pm 0.067 \mathrm{~cm} 3 / \mathrm{g}$. The average interstitial velocity during phosphate treatment was $7.2 \mathrm{~cm} / \mathrm{h}(5.6 \mathrm{ft} /$ day $)$, and during groundwater flow was $4.0 \mathrm{~cm} / \mathrm{h}(3.0 \mathrm{ft} /$ day $)$. Flow rates were maintained at a constant velocity using Hitachi L6200 HPLC pumps. All system tubing was stainless steel or PEEK, and inlet solutions were covered with foil to minimize microbial growth due to light for these long-term experiments. Experiments were conducted at $22^{\circ} \mathrm{C}$. Effluent samples were collected sequentially using a drip fraction collector (ISCO Foxy 200). Samples were then filtered 
$(0.45 \mu \mathrm{m})$ and preserved for specified analysis: a) $0.5 \mathrm{~mol} / \mathrm{L} \mathrm{HNO}_{3}$ for uranium analysis, b) $2 \% \mathrm{HNO}_{3}$ for cations, and c) no preservation for anions.

Table 3.1. Description of 1-D Water-Saturated Column Experiments

\begin{tabular}{|c|c|c|c|c|}
\hline \# & treatment & $\begin{array}{l}\text { P04 vel. } \\
\text { (ft/day) }\end{array}$ & $\begin{array}{l}\text { GW vel. } \\
\text { (ft/day) }\end{array}$ & analysis* \\
\hline-- & untreated, no flow & & & 3 \\
\hline \multicolumn{5}{|c|}{ baseline long-term water flow - no PO4 treatment } \\
\hline A100 & untreated, 200 pv groundwater & -- & 2.75 & $1,2,3$ \\
\hline A101 & untreated 450 pv river water & -- & 3.76 & $1,2,3$ \\
\hline A109 & untreated, $190 \mathrm{pv}$ synthetic groundwater & -- & 3.35 & $1,2,3$ \\
\hline \multicolumn{5}{|c|}{ variable reaction time, no flow } \\
\hline A105 & 47 mM PO4 treatment, 19 h, no flow & 2.69 & -- & 2,3 \\
\hline A108 & $47 \mathrm{mM}$ PO4 treatment, $4400 \mathrm{~h}$, no flow & 4.97 & & 2,3 \\
\hline \multicolumn{5}{|c|}{ variable P04 treatment, $98 \mathrm{~h}$ reaction time before flow } \\
\hline A103 & 47 mM PO4 treatment, 450 pv river water & 6.87 & 2.97 & $1,2,3$ \\
\hline A102 & $47 \mathrm{mM}$ PO4 treatment, $214 \mathrm{pv}$ groundwater & 6.76 & 2.83 & $1,2,3$ \\
\hline A104 & $8 \mathrm{mM}$ PO4 treatment, 214 pv groundwater & 4.80 & 2.36 & $1,2,3$ \\
\hline \multicolumn{5}{|c|}{47 mM PO4 treatment, variable reaction time before flow } \\
\hline A117 & PO4 then $19 \mathrm{~h}$ lag before flow, $53 \mathrm{pv}$ synthetic groundwater & 6.08 & 2.89 & 2,3 \\
\hline A118 & PO4 then 286 h lag before flow, 65 pv synth. groundwater & 6.35 & 2.94 & 2,3 \\
\hline A119 & PO4 then $286 \mathrm{~h}$ lag before flow, $118 \mathrm{pv}$ low U real gw & 6.88 & 3.99 & 2,3 \\
\hline A106 & PO4 then $573 \mathrm{~h}$ lag before flow, 150 pv synth. groundwater & 6.69 & 2.74 & 2,3 \\
\hline A107 & PO4 then $1915 \mathrm{~h}$ lag before flow, $150 \mathrm{pv}$ synth. groundwater & 4.83 & 3.02 & 2,3 \\
\hline \multicolumn{5}{|c|}{$47 \mathrm{mM}$ P04, $3000 \mathrm{ppm}$ xanthan treatment } \\
\hline A112 & 3000 ppm xanthan only, 953 h lag before flow, 62 pv synth. gw & 4.57 & 2.56 & 2,3 \\
\hline A111 & 47 mM PO4 + 3000 ppm xanthan, no flow & 5.53 & -- & 2,3 \\
\hline A110 & $47 \mathrm{mM}$ PO4 +3000 ppm xanthan, $1100 \mathrm{~h}$ lag, 63 pv synth. gw & 5.17 & 2.35 & 2,3 \\
\hline
\end{tabular}

Large-scale infiltration columns were also used to investigate optimization of phosphate delivery to smear zone sediments. These infiltration columns were conducted varying: a) phosphate solution infiltration rate, b) volume of phosphate infiltration pulse, c) volume of water pulse after phosphate pulse, d) different grain size distribution, and e) different sediment uranium spatial/geochemical distribution (Table 3.2). Infiltration experiments were conducted in columns of $5.0 \mathrm{~cm}$ (2 in.) diameter clear PVC that were 1.0 to $3.0 \mathrm{~m}$ ( 3 to $10 \mathrm{ft}$ ) length, with multiple access ports for sediment sampling along the length. The columns were packed with a Hanford 300 area sediment mixture representative of the same clay, silt, sand, and gravel fractions as the 300 Area polyphosphate infiltration site or injection site, as described in detail in the following section. Infiltration experiments consisted of dripping the polyphosphate solution at the column top at a specified rate for 2 to 10 pore volumes. In some cases, drip a non-phosphate solution was used to advect phosphate to depth. Effluent dripping out the bottom of the 3-m (10-ft) columns was collected in a drip fraction collector during solution infiltration and for hundreds of hours after solution infiltration stopped. Aqueous samples were analyzed for uranium, bromide, and phosphate concentration. Sediment was analyzed for uranium surface phases (described in the following section) using access ports and at the end of the experiment. The columns averaged $45 \%$ water saturation, which reached a steady state during infiltration of the solution, but water advection rate decreased asymptotically after solution infiltration stopped. Uranium mass balance on water leached was calculated from the effluent concentrations and the instantaneous flow rate for each sample, as the flow rate changed in these unsaturated columns. 
Table 3.2. Description of Infiltration Column Experiments

\begin{tabular}{|c|c|c|c|c|c|c|c|c|c|}
\hline \# & infiltration water & $\begin{array}{c}\text { column } \\
\text { height } \\
(\mathrm{cm})\end{array}$ & $\begin{array}{c}\text { Darcy } \\
\text { flux } \\
(\mathrm{cm} / \mathrm{h})\end{array}$ & $\begin{array}{c}\text { PO4 } \\
\text { infiltrate } \\
(h, P V)\end{array}$ & $\begin{array}{c}\text { water } \\
\text { infiltrate } \\
(h, P V)\end{array}$ & $\begin{array}{c}\text { drain } \\
\text { (h) }\end{array}$ & $\begin{array}{c}\text { grain size } \\
\text { distribution* }\end{array}$ & $\begin{array}{l}\text { sediment } \\
\text { uranium distribution }\end{array}$ & analysis^ \\
\hline \multicolumn{10}{|c|}{ baseline infiltration, tracer only } \\
\hline A69 & Groundwater, $\mathrm{Br}$ - tracer & 100 & 12.5 & none & 42,26 & none & 2, homogeneous & homog., low U sediment & 1,2 \\
\hline A70 & $0.28 \mathrm{M} \mathrm{KNO} 3, \mathrm{Br}$ - tracer & 100 & 12.5 & none & 42,26 & none & 2, homogeneous & homog., low U sediment & 1,2 \\
\hline \multicolumn{10}{|c|}{ large $\mathrm{PO} 4$ pulse for $\mathrm{PO} 4$ retardation } \\
\hline A60 & $47 \mathrm{mM}$ PO4 & 100 & 8.6 & $29,18.3$ & none & 135 & 1 , homogeneous & homog., low U sediment & $1,3,5$ \\
\hline A61 & $47 \mathrm{mM}$ PO4 & 100 & 1.25 & $30.2,1.8$ & none & 135 & 2 , homogeneous & homog., low U sediment & $1,3,5$ \\
\hline A62 & 47 mM PO4 & 100 & 1.25 & $30.2,1.8$ & none & 135 & 2 , homogeneous & $300 \mathrm{ppb} U(\mathrm{aq})$ initial pulse & $1,3,5$ \\
\hline A63 & $47 \mathrm{mM}$ PO4 & 100 & 1.25 & $30.2,1.8$ & none & 135 & 3 , homogeneous & 300 ppb U(aq) initial pulse & $1,3,5$ \\
\hline A64 & 47 mM PO4 & 100 & 12.5 & 26,16 & none & 90 & 2, homogeneous & $300 \mathrm{ppb} \cup$ aq $50-65 \mathrm{~cm}$ depth & $1,3,4,5$ \\
\hline A65 & 47 mM PO4 & 100 & 12.5 & 26,16 & none & 90 & 2 , homogeneous & $\mathrm{U}-\mathrm{CO} 3$ at $50-65 \mathrm{~cm}$ depth & $1,3,4,5$ \\
\hline A66 & 47 mM PO4 & 300 & 12.5 & $50,5.5$ & none & 150 & 2, homogeneous & $300 \mathrm{ppb} U$ aq $180-200 \mathrm{~cm}$ depth & $1,3,4,5$ \\
\hline A67 & 47 mM PO4 & 300 & 12.5 & $50,5.5$ & none & 150 & 2, homogeneous & U-CO3 at $180-200 \mathrm{~cm}$ depth & $1,3,4,5$ \\
\hline \multicolumn{10}{|c|}{ vary infiltration rate, large $\mathrm{PO4}$ pulse } \\
\hline A71 & $47 \mathrm{mM} \mathrm{PO} 4,0.8 \mathrm{mM} \mathrm{Br}$ & 300 & 29 & 26,13 & none & 100 & 2, homogeneous & \multicolumn{2}{|c|}{$300 \mathrm{ppb} \cup$ aq $200-300 \mathrm{~cm}$ depth $1,2,3,4,5$} \\
\hline A72 & $47 \mathrm{mM} \mathrm{PO} 4,0.8 \mathrm{mM} \mathrm{Br}$ & 300 & 12.5 & $17.3,6$ & none & 253 & 2, homogeneous & \multirow{2}{*}{\multicolumn{2}{|c|}{$\begin{array}{l}300 \mathrm{ppb} \mathrm{U} \text { aq } 200-300 \mathrm{~cm} \text { depth } 1,2,3,4,5 \\
300 \mathrm{ppb} \mathrm{U} \text { aq } 200-300 \mathrm{~cm} \text { depth } 1,2,3,4,5\end{array}$}} \\
\hline A73 & $47 \mathrm{mM} \mathrm{PO} 4,0.8 \mathrm{mM} \mathrm{Br}$ & 300 & 6.0 & 125,11 & none & 290 & 2, homogeneous & & \\
\hline A74 & $47 \mathrm{mM} \mathrm{PO} 4,0.8 \mathrm{mM} \mathrm{Br}$ & 300 & 3.0 & 251,12 & none & 458 & 2, homogeneous & $300 \mathrm{ppb}$ U aq $200-300 \mathrm{~cm}$ depth & $1,2,3,4,5$ \\
\hline \multicolumn{10}{|c|}{ short P04 pulse followed by water pulse } \\
\hline A75 & $47 \mathrm{mM} \mathrm{PO} 4,0.8 \mathrm{mM} \mathrm{Br}$ & 300 & 12.5 & $12,2.4$ & $12,2.4$ & 410 & 2, homogeneous & $300 \mathrm{ppb}$ U aq $200-300 \mathrm{~cm}$ depth & $1,2,3,5$ \\
\hline A76 & $47 \mathrm{mM} \mathrm{PO} 4,0.8 \mathrm{mM} \mathrm{Br}$ & 300 & 12.5 & $12,2.1$ & none & 410 & 2 , homogeneous & $300 \mathrm{ppb}$ U aq $200-300 \mathrm{~cm}$ depth & $1,2,3,5$ \\
\hline A77 & $47 \mathrm{mM} P 04,0.8 \mathrm{mM} \mathrm{Br}$ & 300 & 12.5 & $12,1.6$ & $12,2.4$ & 410 & 2,4 heterogeneous & $300 \mathrm{ppb} \cup$ aq $200-300 \mathrm{~cm}$ depth & $1,2,3,5$ \\
\hline A78 & $47 \mathrm{mM} \mathrm{PO} 4,0.8 \mathrm{mM} \mathrm{Br}$ & 300 & 12.5 & $12,1.8$ & none & 410 & 2,4 heterogeneous & $300 \mathrm{ppb} \cup$ aq $200-300 \mathrm{~cm}$ depth & $1,2,3,5$ \\
\hline \multicolumn{10}{|c|}{ multiple P04/H2O pulses of short P04 pulse followed by water pulse } \\
\hline A113 & $47 \mathrm{mM} \mathrm{PO4,} 0.8 \mathrm{mM} \mathrm{Br}$ & 300 & 12.5 & 30,7 & none & 216 & 2, homogeneous & high U sediment $200-300 \mathrm{~cm}$ & $1,2,3,4,5$ \\
\hline A114 & $47 \mathrm{mM} \mathrm{PO} 4,0.8 \mathrm{mM} \mathrm{Br}$ & 300 & 12.5 & $15,3.5$ & $15,3.5$ & 216 & 2, homogeneous & high $U$ sediment $200-300 \mathrm{~cm}$ & $1,2,3,4,5$ \\
\hline A115 & $47 \mathrm{mM} \mathrm{PO} 4,0.8 \mathrm{mM} \mathrm{Br}$ & 300 & 12.5 & $10,2.3$ & $20,4.6$ & 216 & 2, homogeneous & high U sediment $200-300 \mathrm{~cm}$ & $1,2,3,4,5$ \\
\hline A116 & $47 \mathrm{mM} \mathrm{PO} 4,0.8 \mathrm{mM} \mathrm{Br}$ & 300 & 12.5 & $10,2.3$ & $20,4.6$ & 216 & 2 , homogeneous & high $U$ sediment $200-300 \mathrm{~cm}$ & $1,2,3,4,5$ \\
\hline \multicolumn{10}{|c|}{ multiple $\mathrm{PO4} / \mathrm{H2O}$ pulses of varying infiltration rate } \\
\hline A120 & $47 \mathrm{mM} \mathrm{PO} 4,0.8 \mathrm{mM} \mathrm{Br}$ & 300 & 6.0 & $21,2.3$ & $43,4.6$ & 64 & 2, homogeneous & high U sediment $200-300 \mathrm{~cm}$ & $1,2,3,4,5$ \\
\hline A121 & $47 \mathrm{mM} P 04,0.8 \mathrm{mM} \mathrm{Br}$ & 300 & 6.0 & $43,4.6$ & $21,2.3$ & 64 & 2, homogeneous & high $U$ sediment $200-300 \mathrm{~cm}$ & $1,2,3,4,5$ \\
\hline A122 & $47 \mathrm{mM} \mathrm{PO} 4,0.8 \mathrm{mM} \mathrm{Br}$ & 300 & 3.0 & $86,4.6$ & $43,2.3$ & 130 & 2, homogeneous & high U sediment $200-300 \mathrm{~cm}$ & $1,2,3,4,5$ \\
\hline
\end{tabular}




\subsection{Sediments and Solutions}

All of the columns for the water-saturated experiments were packed with a Hanford 300 Area composite of uranium-contaminated sediment from borehole C7117 (Table 3.3). Four depths of sediment in borehole C7117 (23.5 to $33.5 \mathrm{ft}$ ) that were uranium contaminated had an average fraction of sand/silt/clay $(<2 \mathrm{~mm})$ of $34 \%$, so the composite sediment was made with this $34 \%$ fraction of $<2 \mathrm{~mm}$ and $66 \% \# 20$ silica sand substituting for the gravel fraction. Therefore the composited sediment was expected to exhibit the same adsorption of uranium complexes as a field sediment. The large-scale infiltration columns of $5.1-\mathrm{cm}$ (2.0-in.) diameter by $914 \mathrm{~cm}(3 \mathrm{ft})$ or $305 \mathrm{~cm}$ $(10 \mathrm{ft})$ length, used $3.9 \mathrm{~kg}$ or $11.7 \mathrm{~kg}$ of sediment (respectively). These columns were packed with sediment composited from dozens of 300 Area cores from the field infiltration site, based on grain size distributions of the 300 Area infiltration and injection sites (Table 3.4). Four grain size

Table 3.3. Composite Sediment Used in Stop Flow Experiments

\begin{tabular}{lcc}
$\begin{array}{l}\text { sediment } \\
\text { borehole, depth }\end{array}$ & $\begin{array}{c}\text { sediment } \\
\mathbf{\%} \mathbf{2} \mathbf{~ m m}\end{array}$ & $\begin{array}{c}\text { composite } \\
\text { \% by wt }\end{array}$ \\
\hline C7117, 23.5-24' & 33.0 & 10.2 \\
C7117, 30.5-31' & 26.1 & 10.2 \\
C7117, 32-32.5' & 43.3 & 10.2 \\
C7117, 33-33.5' & 93.0 & 3.4 \\
\#20 accusand (for 66\% gravel) & 66.0 \\
\hline
\end{tabular}
distributions were used in infiltration experiments.

Table 3.4. Grain Size Distributions Used In Infiltration Columns

\begin{tabular}{|c|c|c|c|c|c|}
\hline Site & $\begin{array}{l}\text { silt/clay } \\
<53 \text { um }\end{array}$ & $\begin{array}{c}\text { sand } \\
0.053-2 \mathrm{~mm}\end{array}$ & $\begin{array}{l}\text { pea gravel } \\
2-4.75 \mathrm{~mm}\end{array}$ & $\begin{array}{l}\text { coarse gravel } \\
4.75-12.75 \mathrm{~mm}\end{array}$ & $\begin{array}{c}\text { vc gravel } \\
>12.75 \mathrm{~mm}\end{array}$ \\
\hline 300A injection Site & 4.0 & 15.0 & 40.0 & 41.0 & \\
\hline 300A Infiltration Site & 16.95 & 38.63 & 4.83 & 28.58 & 11.00 \\
\hline Injection Site Composite & 4.0 & 15.0 & 81.0 & & \\
\hline Infiltration Site Composite & 16.95 & 38.63 & 44.4 & & \\
\hline Coarse Infiltration Site Composite & 1.0 & 10.0 & 89.0 & & \\
\hline
\end{tabular}

The C7117 composite sediment used in water-saturated experiments contained a total of $1.55 \mu \mathrm{g} \mathrm{U} / \mathrm{g}$ sediment (Figure 3.1a), higher than the composite sediment used in infiltration experiments with $0.48 \mu \mathrm{g} / \mathrm{g}$. The aqueous and adsorbed fraction was $8 \%$, and acetate-extractable fractions were $72 \%$, giving a total labile uranium of $1.29 \mu \mathrm{g} / \mathrm{g}$ and nonlabile uranium $0.264 \mu \mathrm{g} / \mathrm{g}$. Because of increased surface area (and possibly difference in adsorption to different minerals), finer grain size fractions did contain a much higher mass of uranium (Figure 3.1b, injection site field sediment). However, at field scale, the uranium mass associated with gravel is considerable (Figure 3.1c) because of the high fraction gravel (81\% for the injection site, $44 \%$ for the infiltration site, Table 3.1). Although the surface area of gravel is small, uranium may be associated with precipitate phases coating the gravel. 

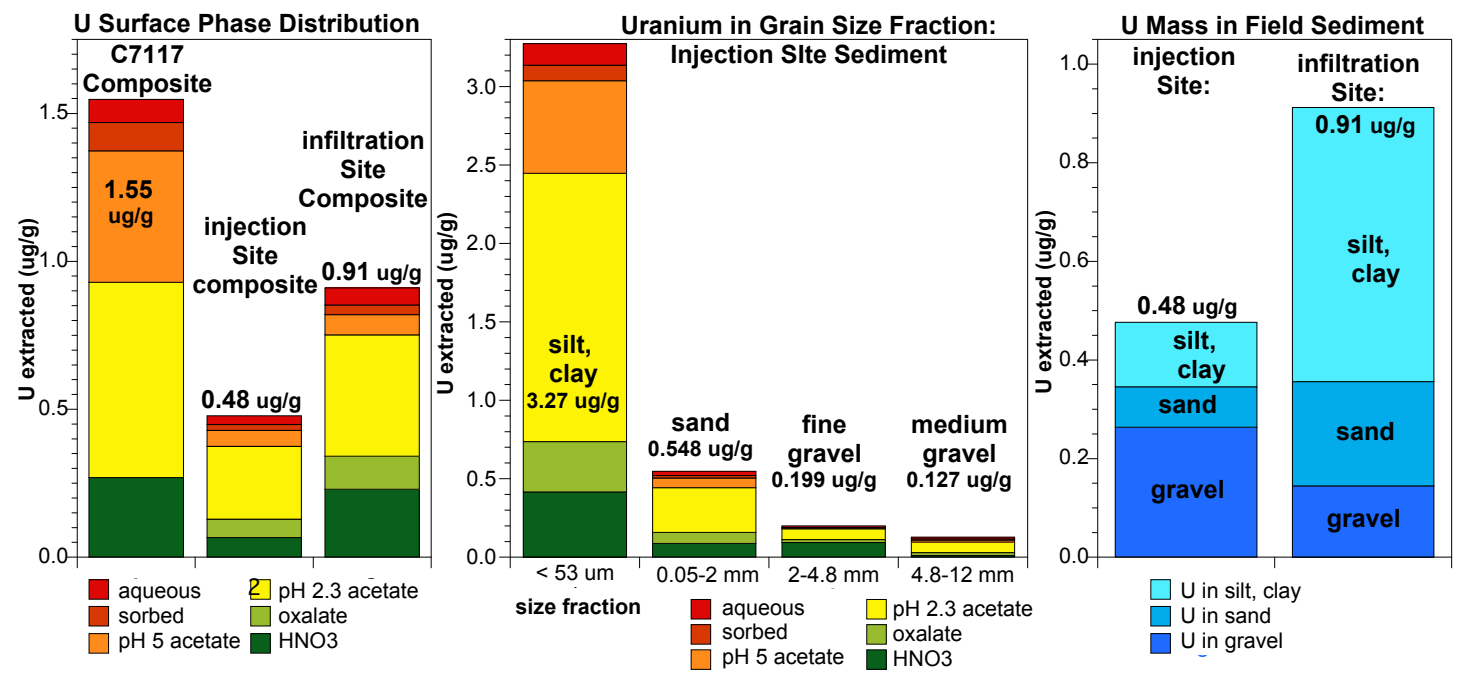

Figure 3.1. Uranium Adsorption at Different Uranium Concentration and Water Composition

In the 300 Area, groundwater, river water, or mixtures of both can advect through sediments in the aquifer and smear zone. The characteristics of uranium leaching, therefore, vary because of increased carbonate dissolution (in waters that are less than carbonate saturated) or highly mobile uranium adsorption can be influenced by the overall ionic strength of the water. Uranium leaching from river and groundwater of differing composition provides endpoints of expected leaching behavior, so stop flow experiments were conducted using water of differing chemical composition. Three baseline stop-flow experiments were conducted that include:

1. Hanford 300 Area groundwater (both $13 \mu \mathrm{g} / \mathrm{L}$ uranium and $0.08 \mu \mathrm{g} / \mathrm{L}$ uranium)

2. Columbia River water (5 $\mu \mathrm{g} / \mathrm{L}$ uranium)

3. Synthetic groundwater developed and used by Integrated Field Research Challenge project funded by the DOE Office of Science (contains no uranium).

The phosphate solution used in both the small-scale water saturated stop-flow and large-scale infiltration experiments contained $47 \mathrm{mM}$ orthophosphate and $1.75 \mathrm{mM}$ tripolyphosphate (i.e., $10 \%$ phosphate from tripolyphosphate) mixed with Columbia River water (planned for use at field scale). More specifically, three phosphate compounds were used to achieve a final $\mathrm{pH}$ of 7.5: $39.9 \mathrm{mM}$ $\mathrm{Na}_{2} \mathrm{HPO}_{4}(\mathrm{pH} 9.1), 7.5 \mathrm{mM} \mathrm{NaH}{ }_{2} \mathrm{PO}_{4}(\mathrm{pH} 4.5)$, and $1.75 \mathrm{mM}$ Na-tripolyphosphate (pH 9.5). The total phosphate was $52.66 \mathrm{mM}$ (and $90.8 \mathrm{mM} \mathrm{Na}$ ). The phosphate-xanthan injection solution consisted of the same mixture of phosphates (above), but additionally with $3000 \mathrm{ppm}$ xanthan.

Calcium was not added, but is present on the sediment and becomes prevalent in solution by ion exchange. With an average cation exchange capacity of 1.2 to $2.0 \mathrm{meq} / 100 \mathrm{~g}$ with $77 \%$ of ion exchange sites with $\mathrm{Ca}^{2+}$, the total surface $\mathrm{Ca}$ available is 0.9 to $1.5 \mathrm{mmol} / 100 \mathrm{~g}$, although only a fraction of the calcium would exchange in the high Na-bearing phosphate solution (Szecsody et al. 2009). Because phosphate initially precipitates as amorphous monocalcium phosphate $(\mathrm{Ca}: \mathrm{P}=0.5)$, assuming all of the surface $\mathrm{Ca}^{2+}$ were available (and assuming field bulk density and porosity), a total of $117 \mathrm{mM}$ of phosphate could be precipitated. Over the first several weeks, the amorphous monocalcium phosphate 
recrystallizes to di- to octa-calcium phosphate, and eventually forms hydroxyapatite (Sumner 2000) over time periods of months to years. As hydroxyapatite $(\mathrm{Ca}: \mathrm{P}=1.67)$, the total surface $\mathrm{Ca}^{2+}$ would precipitate $35 \mathrm{mM}$ phosphate.

\subsection{Solid and Aqueous Solution Analysis}

Aqueous samples were measured for cations, anions, phosphate, and uranium. Pore water cations/ elements (Ca, Na, K, Mg, Fe, P, Al, Si) were measured using an inductively coupled plasma optical emission spectrometer (ICP-OES, Perkin-Elmer Optima 2100DV). These elements were predominantly present as cations except for $\mathrm{Si}$, which is present as $\mathrm{SiO}_{2}$ (aq). Aqueous phosphate concentration was measured colormetrically (Hach 8178 method) using a Hach DR 2000 UV-VIS spectrophotometer. Aqueous carbonate was measured on a Shimatzu carbon analyzer. Six anions were measured using a Dionex ICS 2000 ion chromatograph $\left(\mathrm{F}^{-}, \mathrm{Cl}^{-}, \mathrm{NO}_{2}^{-}, \mathrm{Br}^{-}, \mathrm{SO}_{4}^{-2}, \mathrm{NO}_{3}^{-}\right)$. Aqueous $\mathrm{U}(\mathrm{VI})$ from extractions was measured by laser-induced kinetic phosphorimetry (KPA, Brina and Miller 1992). Phosphate precipitates were measured on sediments in experiments using a $0.5-\mathrm{mol} / \mathrm{L} \mathrm{HNO}_{3} \times 15$-minute extraction (Szecsody et al. 2010).

Sediment samples were analyzed for labile and nonlabile uranium on surfaces or precipitated as mineral phases using a series of six sequential liquid extractions: a) aqueous uranium, b) adsorbed uranium, c) weak acetic acid extractable, d) strong acetic acid extractable, e) oxalate extractable, and f) nitric acid extractable. Uranium is present as aqueous or adsorbed as predominantly $\mathrm{Ca}_{2} \mathrm{UO}_{2}\left(\mathrm{CO}_{3}\right)_{3}$ aq, and $\mathrm{CaUO}_{2}\left(\mathrm{CO}_{3}\right)_{3}{ }^{2-}$ at $\mathrm{pH} 8$ (Liu et al. 2008; Zachara et al. 2007). Aqueous uranium was defined as extractable with natural groundwater, whereas adsorbed uranium species were extracted with a carbonate solution $\left(0.0114 \mathrm{~mol} / \mathrm{L} \mathrm{NaHCO}_{3}, 0.0028 \mathrm{~mol} / \mathrm{L} \mathrm{Na}_{2} \mathrm{CO}_{3}, 1 \mathrm{~h}\right.$ (Smith and Szecsody 2011). Extractant solutions used after the adsorbed uranium extraction are operationally defined, dissolving one or more uranium minerals: a) $1 \mathrm{~mol} / \mathrm{L}$ sodium acetate $(\mathrm{pH} 5.1 \mathrm{~h})$; b) acetic acid ( $\mathrm{pH} 2.3,5$ days, Kohler et al. 2004); c) $0.1 \mathrm{~mol} / \mathrm{L}$ ammonium oxalate, $0.1 \mathrm{~mol} / \mathrm{L}$ oxalic acid $(1 \mathrm{~h})$; and d) $8 \mathrm{~mol} / \mathrm{L} \mathrm{HNO}_{3}, 95^{\circ} \mathrm{C}, 2 \mathrm{~h}$. Uranium associated with carbonates is dissolved in the two acetate extractions. Na-boltwoodite is predominantly dissolved in the acetic acid extraction (85\%, Szecsody et al. 2010). The oxalate extraction dissolves primarily amorphous and crystalline oxides (Chao and Zhou 1983). Total digestion of untreated sediments results in an additional $20 \%$ uranium. Total labile uranium is defined as the sum of aqueous, adsorbed, and the two acetate extractions.

\subsection{Xanthan-Phosphate System and Rheological Measurements}

To characterize the influence of xanthan on the rate of removal of phosphate from solution (caused by both phosphate adsorption and precipitation), a series of batch experiments were conducted to measure the aqueous phosphate in solution (in contact with Hanford sediment) with differing concentration of xanthan $(0,500,1000,1500,2000 \mathrm{ppm})$. The $47-\mathrm{mM}$ polyphosphate solution was used in groundwater. Xanthan, phosphate, and sediment were mixed in 100-ml bottles at a sediment/solution ratio of $1 \mathrm{~g} / 10 \mathrm{~mL}$. Samples were taken immediately after mixing and continued up to more than $200 \mathrm{~h}$ for phosphate concentration measurement. Batch U-sediment adsorption experiments were conducted at 10, 100, and $1000 \mathrm{ppb}$ uranium, with xanthan concentrations of 0,700 , and $2000 \mathrm{ppm}$.

In order to evaluate the longevity of the injected xanthan-phosphate solution viscosity in the sediment, one set of batch tests were conducted to test the influence of polymer concentration on viscosity 
change (decrease) in the presence of Hanford sediment. Xanthan concentrations between 600 and $2000 \mathrm{mg} / \mathrm{L}$ were tested and temperature of $17^{\circ} \mathrm{C}$ was applied. Solution samples were taken for rheology measurement at $0.25,168,336$, and $504 \mathrm{~h}$. The xanthan solution and sediment mixtures were settled to separate the sediment grains from the solution before rheology measurement. 1-D column experiments were also used to study the xanthan viscosity decrease in settings with field solution/sediment ratio. A $1500-\mathrm{mg} / \mathrm{L}$ xanthan solution prepared in tap water was injected into columns packed with sediments. Columns with a length of $12.5 \mathrm{~cm}$ and a $5.0-\mathrm{cm}$ internal diameter were used. Solutions were drained or pushed out with nitrogen gas at $0.17 \mathrm{~h}, 168 \mathrm{~h}$ (1 week), $504 \mathrm{~h}$ ( 3 weeks), and $1512 \mathrm{~h}$ ( 9 weeks) after injection for rheology measurement.

Two intermediate-scale two-dimensional (2-D) flow cell experiments, FC-1 and FC-2, were conducted to improve the understanding of xanthan solution rheological behavior in contact with sediments under continuous flow conditions. The FC-1 test was conducted with Accusand (20/30 mesh), and the FC-2 test was performed using a Hanford Site sediment composite (infiltration site composite, Table 3.4). Both experiments were conducted in a 0.5-m-long, 0.4-m-tall, and 0.05-m-wide flow cell. The flow cell was packed under saturated conditions to avoid entrapping of air bubbles. The average porosity and dry bulk density values for the site sediment mixture were 0.32 and $1.82 \mathrm{~g} / \mathrm{cm}^{3}$, respectively. The xanthan solution was not dyed and water was dyed blue in FC-1, while the polymer solution was dyed with a red food dye at $100-\mathrm{mg} / \mathrm{L}$ concentration but water was not colored for FC-2. The influence of the dye on the rheology is negligible. Denoting the left-bottom corner of the flow cell as ( $\mathrm{x}$ - horizontal direction, $\mathrm{z}$ - vertical direction $)=(0 \mathrm{~cm}, 0 \mathrm{~cm})$, the polymer solutions were injected at $(\mathrm{x}, \mathrm{z})=(20 \mathrm{~cm}$, $20 \mathrm{~cm}$ ) at a concentration of $5000 \mathrm{mg} / \mathrm{L}$ with a rate of $50 \mathrm{ml} / \mathrm{min}$ for 6 minutes. Water flow with a rate of $0.20 \mathrm{~cm} / \mathrm{min}$. was applied to the left hand side of the flow cell. The water level in the constant-head chamber was kept at $\mathrm{z}=0.4 \mathrm{~m}$. Water flow was kept constant during the xanthan solution injection, and was continued through the whole testing period. In FC-1, water without dye was injected through the flow cell after 2 weeks flushing with blue-dyed water to observe changes inside the xanthan blob. Pictures were taken throughout the experiments.

Rheological measurements were conducted using a rotational rheometer Physica MCR 101 (Anton Paar USA Inc., Ashland, Virginia). The measurement shear rate range was between 0.1 and $200 \mathrm{~s}^{-1}$. A built-in temperature control chamber enabled the setting of desired temperatures for measurements. All samples were measured at $25 \pm 0.1^{\circ} \mathrm{C}$. 



\subsection{Results and Discussion}

The effect of phosphate treatment on uranium leaching mass and rate from field-contaminated sediments is described in the following sections:

- 4.1 - Influence of phosphate treatment on uranium leaching rate and mass

- 4.2 - Influence of phosphate/sediment reaction time

- 4.3 - Influence of phosphate concentration

- 4.4 - Phosphate delivery by water-saturated injection with xanthan

- 4.5 - Phosphate delivery by infiltration to the smear zone: phosphate distribution, and uranium mobility.

Uranium leaching from Hanford 300 Area sediments is influenced by many factors including decades of pre-treatment contact time, groundwater quality influenced by river-water intrusion that impacts carbonate concentration and total ionic strength, leaching time in terms of slow physical and/or chemical release of uranium from sediment, and the processes by which phosphate treatment alters or coats uranium surface phases.

The influence of phosphate treatment is described in this report by comparison of long-term aqueous uranium leaching of untreated and phosphate-treated sediments and surface-associated uranium were operationally defined by sequential liquid extractions that characterize labile or nonlabile uranium phases. Identification of changes in uranium surface phases by electron microprobe, XRF, or EXAFS/XANES was not conducted in this study. Because the total labile (leachable) uranium in this Hanford 300 Area sediment was low $(1.29 \mu \mathrm{g} / \mathrm{g})$, electron microbe and XRF analysis was unlikely to identify uranium surface phases. X-ray fluorescence was conducted in a previous phosphate study (Shi et al. 2009) using a Hanford 200 Area BX sediment that contained considerably higher uranium concentration $(112 \mu \mathrm{g} / \mathrm{g})$, which did show initial adsorption of uranium to phosphate precipitates, then a slow transformation of uranium to less soluble phases.

Phosphate precipitation in $\mathrm{pH}$ neutral sediments generally follow a sequence of initial precipitation of amorphous monocalcium phosphate, which crystallizes after weeks, then a progression to di- to octacalcium phosphate and finally hydroxyapatite (Sumner 2000) over months to years, as hydroxyapatite is thermodynamically favored at $\mathrm{pH} 7.3$ to 8.3. The Ca:P ratio changes from 1:2 to $1.67: 1$ during this evolution. The aqueous solubility also decreases significantly. Autunite $\left[\mathrm{Ca}\left(\mathrm{UO}_{2}\right)_{2}\left(\mathrm{PO}_{4}\right)_{2} \mathrm{xH}_{2} \mathrm{O}\right]$ can also form, as it is thermodynamically favored. It is hypothesized that due to the slowly changing phosphate precipitates that form, uranium leaching will unlikely decrease during initial treatment, but over months to years, lower solubility hydroxyapatite can form coating uranium surface phases (i.e., uranium-carbonates, sodium-boltwoodite) or uranium phosphate phases may also form. Previous research demonstrated that under high bicarbonate conditions, autunite does not form, but uranium phosphate precipitates do form (Wellman et al. 2008a). 


\subsection{Influence of Phosphate Treatment on Uranium Leaching Mass and Rate}

\subsubsection{Uranium Leached Mass and Aqueous Concentrations}

Aqueous uranium leached from the phosphate-treated sediment columns over hundreds to thousands of hours generally shows decreased uranium mass leaching out and decrease in uranium release rate from phosphate-treated sediment compared with untreated sediment. During continuous groundwater or river flow for phosphate-treated sediments, column effluent uranium was 1 to $10 \mu \mathrm{g} / \mathrm{L}$, compared to 5 to $12 \mu \mathrm{g} / \mathrm{L}$ for untreated sediments at exactly the same flow rate. Uranium effluent concentrations peaked for untreated sediments after 200 to $1000 \mathrm{~h}$ stop flow events to $150 \mu \mathrm{g} / \mathrm{L}$ due to slow uranium release from sediments during the stop flow time interval, which was used to calculate a uranium release rate. Some of the phosphate-treated sediments showed a negative effluent peak ( 0 to $2 \mu \mathrm{g} / \mathrm{L}$ at stop flow events), indicating uranium released from sediment was being removed from solution by the presence of the phosphate precipitate. For 13 column experiments that received phosphate treatment, the average uranium mass advected out of the sediment was $0.385 \pm 0.283 \mu \mathrm{g} / \mathrm{g}$, compared with $0.833 \pm 0.298 \mu \mathrm{g} / \mathrm{g}$ for untreated sediments (three untreated column experiments), or a 54\% decrease in leaching uranium mass over hundreds of pore volumes (Table 4.1 and Figure 4.1). The total labile uranium in this C7117 composite sediment was $1.29 \mu \mathrm{g} / \mathrm{g}$. The mass of uranium leached during 7 to 8 pore volumes of phosphate treatment and a subsequent 50 pore volumes of groundwater flow was calculated, and for the 13 column experiments averaged $0.198 \pm 0.233 \mu \mathrm{g} / \mathrm{g}$, or only $15 \%$ of the total labile uranium in the sediment. Advected uranium mass for experiments in which synthetic groundwater was used leached much higher amount of uranium (average $0.540 \mu \mathrm{g} / \mathrm{g}$ ) compared to experiments in which natural river water or groundwater was used (average $0.193 \mu \mathrm{g} / \mathrm{g}$ ). A comparison of uranium leaching from untreated sediments with groundwater, river water, and synthetic groundwater also showed greater aqueous uranium leached using the higher ionic strength synthetic groundwater (Appendix A). The uranium peak concentration for three untreated sediments averaged $300 \pm 173 \mu \mathrm{g} / \mathrm{L}$ (range 154 to 491), whereas phosphate-treated sediments averaged $89.0 \pm 54.7 \mu \mathrm{g} / \mathrm{L}$ (range 10 to 176). These water-saturated columns showed phosphate treatment decreased the initial peak (even though an increased uranium peak concentration is expected for higher ionic strength water injection) due to additional phosphate-sediment reaction time in some experiments allowing for phosphate to precipitate and uranium to be sequestered, lowering aqueous uranium concentration. Infiltration experimental results described in Section 4.5 showed increased uranium peak concentrations $415 \pm 131 \mu \mathrm{g} / \mathrm{L}$ (range 315 to 764 ) for phosphate solution infiltration compared to a single untreated column with a peak uranium concentration of $323 \mu \mathrm{g} / \mathrm{L}$.

The mass of phosphate added to sediment is three orders of magnitude greater than the total labile uranium in sediment. Most experiments used $47 \mathrm{mmol} / \mathrm{L}$ phosphate, and $60 \mu \mathrm{g} / \mathrm{L}$ uranium in groundwater is equivalent to $3 \times 10^{-4} \mathrm{mmol} / \mathrm{L}\left(\mathrm{PO}_{4}{ }^{3-} / \mathrm{U}\right.$ ratio $\left.=18,600\right)$ and the total labile uranium in sediment $(1.29 \mu \mathrm{g} / \mathrm{g})$ is equivalent to $0.053 \mathrm{mmol} \mathrm{U} / \mathrm{L}$ in solution $\left(\mathrm{PO}_{4}{ }^{3-} / \mathrm{U}\right.$ ratio $\left.=887\right)$. Therefore, phosphate addition to sediment has a low efficiency for uranium removal but becomes more effective over time, indicating the needed reactions are slow. 
Table 4.1. Uranium Mass Balance for Water-Saturated $\mathrm{PO}_{4}$-Treated and Untreated Column Experiments

\begin{tabular}{|c|c|c|c|c|c|c|c|c|}
\hline $\begin{array}{c}\text { exp. } \\
\#\end{array}$ & treatment & $\begin{array}{l}\text { total } \\
\text { labile U* } \\
(\mathbf{u g} / \mathrm{g})\end{array}$ & $\begin{array}{l}\text { advected } \\
\mathrm{U} * * \\
(\mathrm{ug} / \mathrm{g})\end{array}$ & $\begin{array}{l}\text { aq+ads } \\
\mathbf{U} \\
(\mathbf{u g} / \mathrm{g})\end{array}$ & $\begin{array}{c}\text { nonlabile } \\
\mathbf{U}^{\wedge} \\
(\mathbf{u g} / \mathrm{g})\end{array}$ & $\begin{array}{l}\text { initial } \\
\text { peak U } \\
\text { (ug/L) }\end{array}$ & $\begin{array}{l}\text { advected U } \\
\text { during PO4 } \\
(\mathrm{ug} / \mathrm{g}) * * *\end{array}$ & $\begin{array}{l}\text { P04 } \\
\text { remaining } \\
(\mathrm{mg} / \mathrm{g})^{\#}\end{array}$ \\
\hline-- & untreated & 1.290 & -- & 0.170 & 0.264 & -- & -- & -- \\
\hline A100 & untreated, 200 pv GW & 1.278 & 0.707 & 0.030 & 0.170 & 256 & -- & -- \\
\hline A101 & untreated 450 pv RW & 0.978 & 0.619 & 0.016 & 0.330 & 491 & -- & -- \\
\hline A109 & untreated, 190 pv SGW & - & 1.174 & - & -- & 154 & -- & -- \\
\hline A105 & 47 mM PO4 treatment, no flow & 0.655 & 0.0004 & 0.0082 & 0.262 & -- & 0.0004 & 0.197 \\
\hline A108 & 47 mM PO4 treatment, 4400 h, no flow & 0.762 & 0.000 & 0.120 & 0.639 & -- & 0.000 & 0.162 \\
\hline A103 & $\begin{array}{l}47 \text { mM PO4 treatment, } 98 \mathrm{~h} \text { lag before } \\
\text { flow, } 450 \text { pv river water }\end{array}$ & 0.750 & 0.239 & 0.081 & 0.390 & 57 & 0.050 & 0.019 \\
\hline A102 & $\begin{array}{l}47 \mathrm{mM} \text { PO4 treatment, } 98 \mathrm{~h} \text { lag before } \\
\text { flow, } 214 \mathrm{pv} \text { high U groundwater }\end{array}$ & 0.775 & $\wedge \wedge$ & 0.042 & 0.159 & 61 & 0.081 & 0.015 \\
\hline A104 & $\begin{array}{l}8 \mathrm{mM} \text { PO4 treatment, } 98 \mathrm{~h} \text { lag before } \\
\text { flow, } 214 \mathrm{pv} \text { high U groundwater }\end{array}$ & 0.606 & $\wedge \wedge$ & 0.070 & 0.171 & 38 & 0.047 & 0.013 \\
\hline A117 & $\begin{array}{l}47 \mathrm{mM} \text { PO4 treatment, } 19 \mathrm{~h} \text { lag before } \\
\text { flow, } 53 \mathrm{pv} \text { synthetic groundwater }\end{array}$ & 1.025 & 0.481 & 0.002 & 0.644 & 160 & 0.481 & \\
\hline A118 & $\begin{array}{l}47 \text { mM PO4 treatment, } 286 \mathrm{~h} \text { lag } \\
\text { before flow, } 65 \mathrm{pv} \text { synth. groundwater }\end{array}$ & -- & 0.634 & -- & -- & 176 & -- & \\
\hline A119 & $\begin{array}{l}47 \mathrm{mM} \text { PO4 treatment, } 286 \mathrm{~h} \text { lag } \\
\text { before flow, } 118 \mathrm{pv} \text { low } U \text { real gw }\end{array}$ & 1.107 & 0.727 & 0.003 & 0.602 & 146 & 0.727 & \\
\hline A106 & $\begin{array}{l}47 \mathrm{mM} \text { PO } 4 \text { treatment, } 573 \mathrm{~h} \text { lag } \\
\text { before flow, } 150 \mathrm{pv} \text { synth. groundwater }\end{array}$ & 1.283 & 0.644 & 0.080 & 0.462 & 91 & 0.375 & 0.046 \\
\hline A107 & $\begin{array}{l}47 \text { mM PO4 treatment, } 1915 \mathrm{~h} \text { lag } \\
\text { before flow, } 150 \text { pv synth. groundwater }\end{array}$ & 0.911 & 0.400 & 0.081 & 0.692 & 34 & 0.187 & \\
\hline A112 & $\begin{array}{l}3000 \text { ppm xanthan treatment, } 953 \mathrm{~h} \\
\text { lag before flow, } 62 \mathrm{pv} \text { synth. gw }\end{array}$ & 1.049 & 0.668 & 0.044 & 0.389 & 108 & 0.080 & \\
\hline A 111 & $\begin{array}{l}47 \mathrm{mM} \mathrm{PO} 4+3000 \text { ppm xanthan } \\
\text { treatment, no flow }\end{array}$ & 0.619 & 0.076 & 0.102 & 1.034 & 10.5 & -- & 0.280 \\
\hline A110 & $\begin{array}{l}47 \text { mM PO4 + } 3000 \text { ppm xanthan } \\
\text { treatment, } 1100 \text { h lag before flow, } 63 \\
\text { pv synthetic groundwater }\end{array}$ & 0.519 & 0.145 & 0.0003 & 0.743 & 98 & 0.145 & \\
\hline
\end{tabular}

* extractions $1,2,3,4$, and effluent. These extractions changed with advection.

$* *$ effluent total $U$ mass, per $\mathrm{g}$ of sediment

*** during PO4 injection ( $~ 7$ pore volumes, $\sim 20 \mathrm{~h}$ ) and subsequent $50 \mathrm{pv}(\sim 250 \mathrm{~h})$

$\wedge$ as defined by $U$ extracted in $8 \mathrm{M}$ HNO3, 90C, 2 h (extr. 6)

$\wedge \wedge \mathrm{U}$ leached from sediment masked by use of high $\mathrm{U}$ groundwater

\# 47 mM PO4 x 7 pore volumes assumes to precipitate $0.197 \mathrm{mg}$ PO4/g (observed in no flow exp.) 

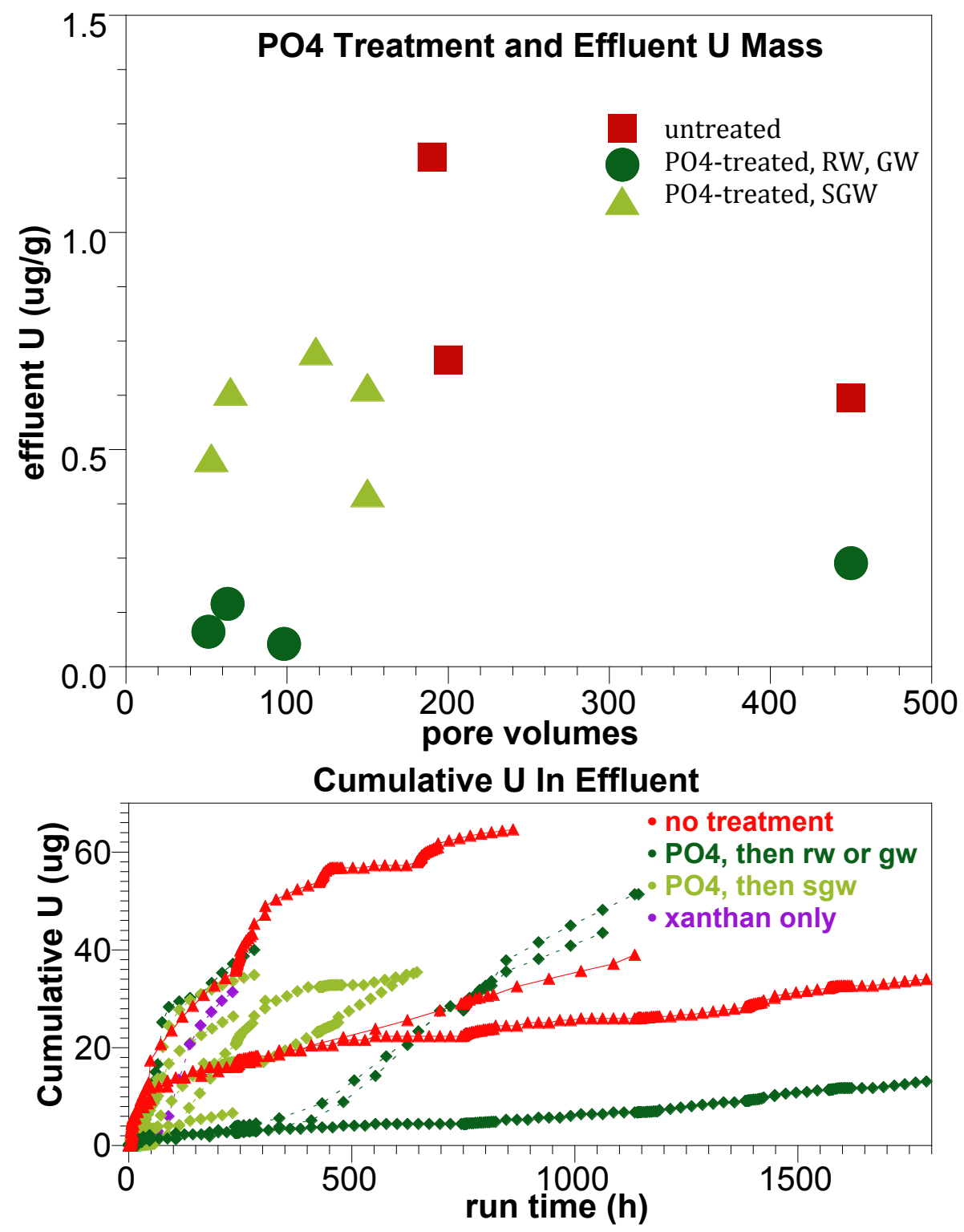

Figure 4.1. Uranium Leached Mass in Effluent for Untreated and $\mathrm{PO}_{4}$-Treated Sediments: (a) Total Effluent Uranium and (b) Cumulative Effluent Uranium

Phosphate extractions were conducted at the end of sediment studies to quantify phosphate precipitate remaining. Two sediment columns that received $47 \mathrm{mM}$ phosphate treatment and no flow (A105, A108, Table 4.1 last column) averaged $0.180 \mathrm{mg} \mathrm{PO} / \mathrm{g}$ sediment. A sediment column that received $47 \mathrm{mM}$ phosphate treatment with $3000 \mathrm{ppm}$ xanthan (A111) showed $0.280 \mathrm{mg} \mathrm{PO} / \mathrm{g}$. A sediment column that received 150 pore volumes of synthetic groundwater flow (A106) had $0.046 \mathrm{mg} / \mathrm{g}$ remaining ( $25 \%$ of initial phosphate). Three columns that received 214 to 450 pore volumes of groundwater or river water advection had $0.015 \mathrm{mg} / \mathrm{g}$ phosphate remaining ( $\sim 8 \%$ of initial phosphate). A graphical representation of the uranium leached from sediment columns (Figure 4.1a) shows the lowest leached mass for phosphatetreated sediments in which real groundwater or river water was used for leaching, with greater uranium 
leached from sediments with synthetic groundwater. Phosphate-treated sediment columns that received synthetic groundwater leached higher uranium mass, at or slightly below some untreated sediment columns (although untreated sediment with synthetic groundwater leached $1.3 \mu \mathrm{g} / \mathrm{g}$, Figure $4.1 \mathrm{~b}$ ).

Phosphate treatment mixtures in the experiments consisted of $39.9 \mathrm{mM} \mathrm{Na}_{2} \mathrm{HPO}_{4}, 7.5 \mathrm{mM} \mathrm{NaH}_{2} \mathrm{PO}_{4}$, and $1.75 \mathrm{mM}$ sodium tripolyphosphate (mixture gives an average $\mathrm{pH}$ of 7.5, total phosphate of $52.65 \mathrm{mM}$, and total $\mathrm{Na}$ of $90.8 \mathrm{mM})$. Major cations $\left(\mathrm{Ca}^{2+}, \mathrm{Na}^{+}, \mathrm{K}^{+}\right)$were monitored during groundwater, river water, and phosphate injections (breakthrough data in Appendix B). Phosphate injections resulted in high phosphate and sodium initial concentrations and depressed calcium concentration, which asymptotically approach subsequent injection water concentration (i.e., river water or groundwater). The calcium concentration is initially depressed as a Ca-poor solution is injected, while $\mathrm{Ca}^{2+}$ on ion exchange sites is utilized, resulting in a Ca-deficient sediment, consistent with results of a previous study with unsaturated sediment columns (Bovaird et al. 2010).

Sequential liquid extractions conducted after phosphate treatments and water advection showed additional uranium mass distribution changes (Figure 4.2). Extraction data accounted for labile uranium (i.e., aqueous in dark red, adsorbed uranium in light red, uranium associated with carbonates in orange and yellow, and effluent uranium in purple) and nonlabile (i.e., immobile) uranium (i.e., $8 \mathrm{M} \mathrm{HNO}_{3^{-}}$ extracted uranium in green). The average nonlabile uranium for untreated sediments of $0.255 \pm$ $0.080 \mu \mathrm{g} / \mathrm{g}$ increased to $0.516 \pm$ $0.259 \mu \mathrm{g} / \mathrm{g}$ for phosphate-treated sediments. Values greater than $0.410 \mu \mathrm{g} / \mathrm{g}$ were statistically different at the $95 \%$ confidence interval. Of the 12 different phosphate treatments, 7 showed significantly greater immobile uranium at the $95 \%$ confidence interval, 2 showed somewhat greater immobile uranium at the $67 \%$ confidence interval, and 3 showed equal or less immobile uranium. Experiments that received significant (i.e., 450 pore volumes over $4000 \mathrm{~h}$ ) river or groundwater flow (A102, A103) showed little change in immobile uranium, consistent with rate data indicating limitation of the phosphate treatment for a significant amount of advective flow.

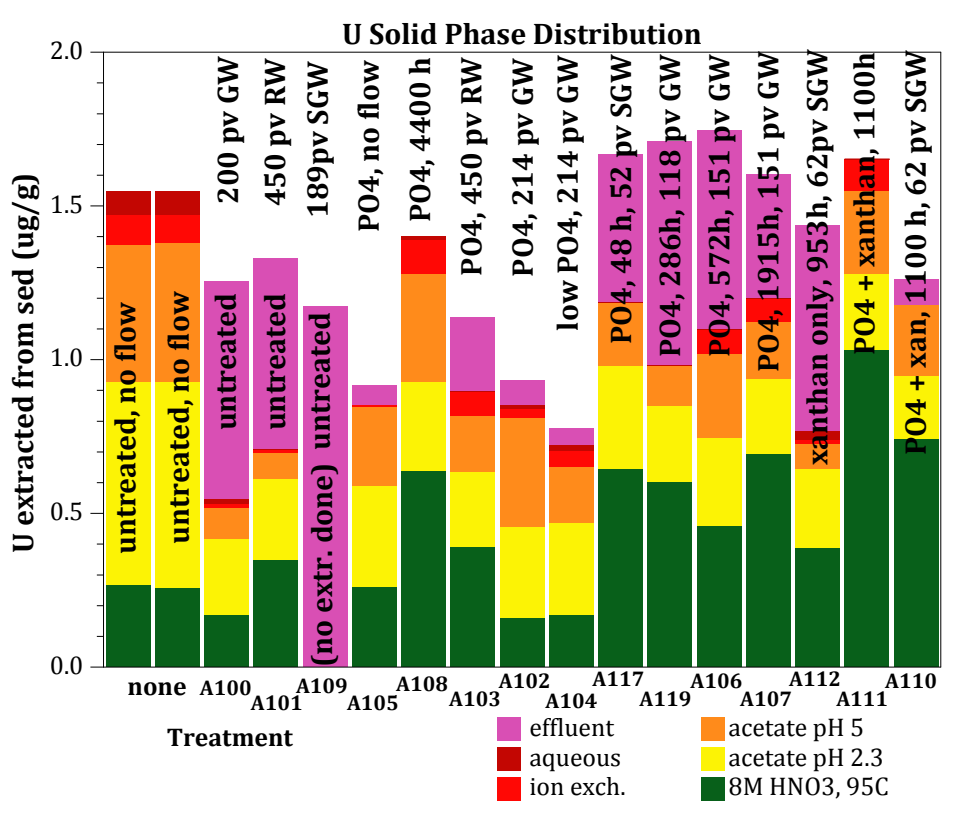

Figure 4.2. Uranium Solid Phase Distribution as Defined by Sequential Liquid Extractions and Eluted Mass

A comparison of a high phosphate treatment to no treatment and river water injection shows the evolution of phosphate-treated sediment from initial high efficiency to decreased efficiency over a long period of time. The total mass leached from the untreated sediment column $(0.619 \mu \mathrm{g} / \mathrm{g})$ decreased $61 \%$ for the phosphate-treated column $(0.239 \mu \mathrm{g} / \mathrm{g})$. The total nonlabile uranium in the untreated sediment $(0.330 \mu \mathrm{g} / \mathrm{g})$ increased as high as $0.693 \mu \mathrm{g} / \mathrm{g}$ for phosphate treatment and no flow (Table 3.1, A108), 
but after 450 pore volumes of river water decreased back to $0.390 \mu \mathrm{g} / \mathrm{g}$ at the end of this phosphatetreated column experiment (A103, Figure 4.3).

These column experiments involved five stop flow events $(200 \mathrm{~h}$ to $1100 \mathrm{~h}$ ) over 450 pore volumes (over a year, Figure 4.3). Water velocities in these stopflow columns averaged $3.5 \mathrm{ft} /$ day (Table 3.1).

The targeted zone for phosphate amendments are the 300 Area smear zone where average water (river water, groundwater) flux is highly variable, but substantially less than in groundwater, so hundreds of pore volumes of water flux shown in these experiments can be equivalent to years or a decade. Uranium mass left in the smear zone is accessible during high water events. Stop flow events allow for both calculation of the uranium release rate from sediment as well as approximating flux cycles in the smear zone (i.e., periods of no flow and then high groundwater flow).

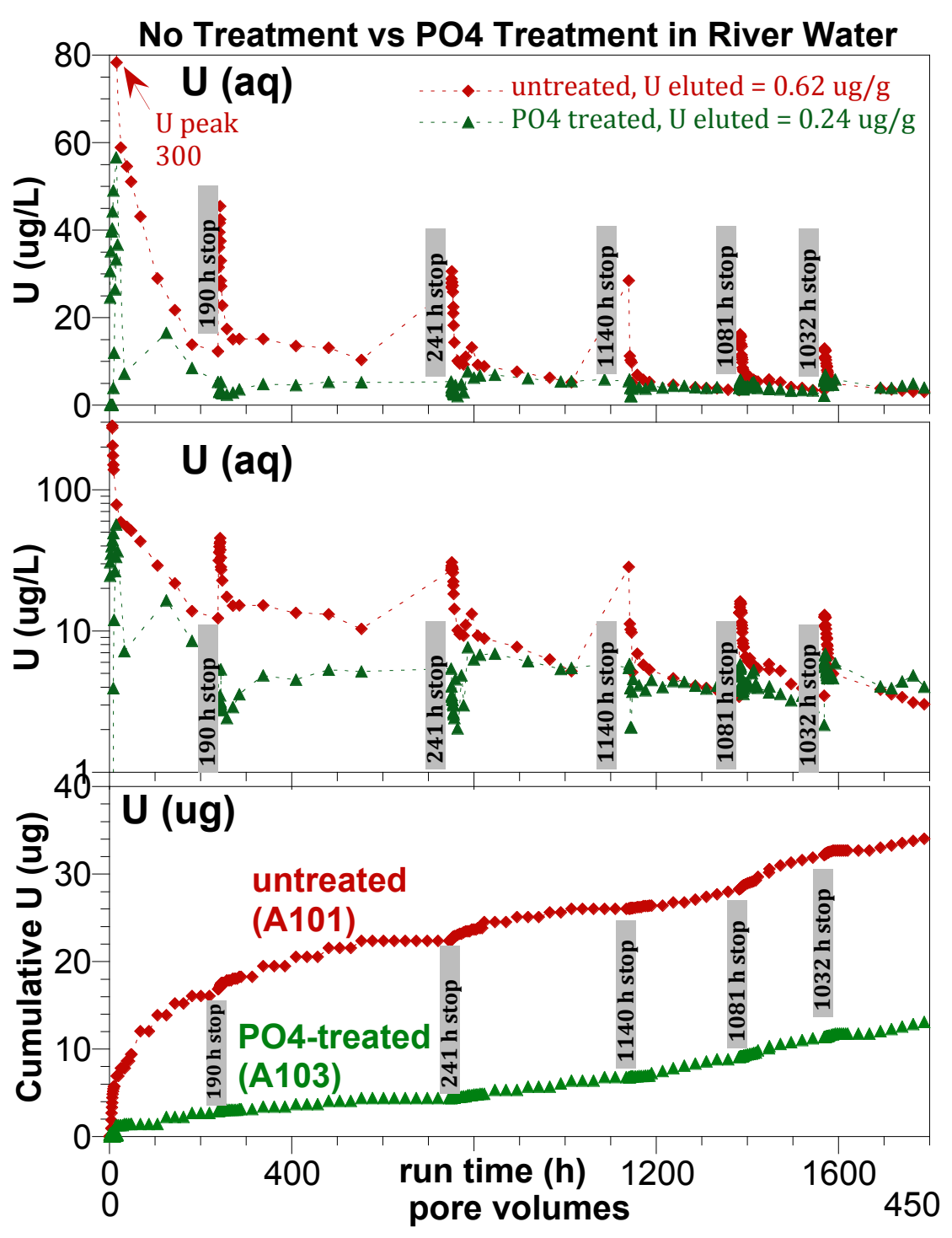

Figure 4.3. Comparison of Uranium Leaching in $\mathrm{PO}_{4}$-Treated to Untreated Sediment with Linear (a) or Log (b) Uranium Concentration and Cumulative Uranium (c)

The comparison of untreated to $47 \mathrm{mM}$ phosphate-treated 300 Area smear zone sediment (Figure 4.3) shows an initial uranium peak much greater for the untreated sediment $(300 \mu \mathrm{g} / \mathrm{L}$ versus $65 \mu \mathrm{g} / \mathrm{L})$. In fact, every subsequent stop flow event had a higher uranium peak for the untreated sediment compared with the phosphate-treated sediment. The most significant observation for phosphate-treated sediments was at stop flow events, the initial uranium "peak" is actually negative (see Figure $4.3 \mathrm{~b}$ ), meaning uranium that is released by physical/chemical mechanisms into pore water is being consumed (i.e., precipitated or coated by precipitates) at a greater 
rate than the release rate. The release rates for untreated and phosphate-treated sediments (Table 4.2) were used to calculate this uranium removal rate in the phosphate-treated sediment column. These uranium removal rates (last column, Table 4.2) show that even with a large excess of phosphate precipitate on the surface, uranium is being removed at a slow rate, as there is some aqueous uranium remaining). The mechanism is not clear whether a uranium-phosphate is precipitating or calciumphosphate precipitate of some sort is recrystallizing and blocking pore water access to uranium in carbonates or in microfractures.

These negative peaks after stop flow events decrease over hundreds of pore volumes (Figure 4.3b, log concentration scale), and uranium effluent concentrations for the phosphatetreated sediment are approaching the untreated sediment. By 450 pore volumes $(5300 \mathrm{~h})$, there is only a small effect of phosphate treatment on uranium removal rates, but the large mass of uranium initially precipitated or coated was not be leaching off (i.e., difference in cumulative leaching mass in Figure 4.3c). It should be noted that there was minimal $(98 \mathrm{~h})$ lag time between phosphate treatment and river water flow for this experiment (influence of lag time on phosphate effectiveness described in the following section). The decreasing effectiveness of the phosphate treatment is readily apparent on the cumulative uranium leaching plots (Figure 4.3c) in which a large amount of uranium mass is quickly released for the untreated sediment (red, A101) in contrast to a very low initial uranium mass released for the phosphate-treated sediment (green, A103). Over time, the release rate of uranium from the phosphate-treated column is increasing (i.e., the rate of uranium removal by phosphate has decreased, last column Table 4.2), and slope (i.e., release rate) approaching that of the untreated sediment. However, a significant amount of uranium (61\%) has not been released due to the phosphate treatment.

\subsubsection{Uranium Leaching Rate}

The rate at which uranium leaches out of phosphate-treated sediment relative to untreated sediment for differing phosphate treatments generally showed less leaching in the presence of phosphate, but results were also highly variable (Table 4.3). At each stop flow event, an increase in aqueous uranium concentration was observed for untreated sediments and a decrease for phosphate-treated sediments. Baseline concentrations for some experiments were low (i.e., $0.0 \mu \mathrm{g} / \mathrm{L}$ for synthetic groundwater and $0.08 \mu \mathrm{g} / \mathrm{L}$ for low uranium groundwater) and showed uranium was leaching from the sediment. A few experiments that used river or groundwater that had higher uranium concentrations, so uranium leaching from sediment was not possible to separate from the influent aqueous uranium (in A100, A102, A103). 
Table 4.3. Uranium Leaching Rates for Untreated and Phosphate-Treated Sediments

\begin{tabular}{|c|c|c|c|c|c|c|c|c|c|c|}
\hline & $\begin{array}{c}\text { exp. } \\
\#\end{array}$ & treatment & $\begin{array}{r}\exp \\
(h)\end{array}$ & $\begin{array}{l}\text { exp. } \\
\text { pore vol }\end{array}$ & $\begin{array}{c}\text { stop } \\
\text { flow } \\
(h) \\
\end{array}$ & $\begin{array}{c}\text { U peak } \\
\text { conc after } \\
\text { stop }(u g / L)\end{array}$ & $\begin{array}{c}\text { U baseline } \\
\text { conc* } \\
\text { (ug/L) }\end{array}$ & $\begin{array}{c}\text { release } \\
\text { rate* } \\
(u g / g / h)\end{array}$ & $\begin{array}{c}\text { U mass** } \\
\text { eluted each } \\
\text { stop }(\mathrm{ug} / \mathrm{g}) \\
\end{array}$ & $\begin{array}{c}\text { U mass } \\
\text { total eff. } \\
(\mathrm{ug} / \mathrm{g})\end{array}$ \\
\hline \multirow{13}{*}{ 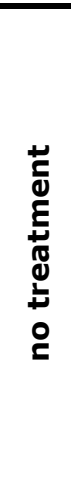 } & A100 & untreated, 200 pv groundwater & 0 & 0 & 0 & 253 & 18.1 & & 0.292 & \\
\hline & & & 240 & 41.0 & 190 & 39.8 & 13.9 & $3.72 E-05$ & 0.235 & \\
\hline & & & 745 & 128 & 241 & 31.4 & 14.4 & $1.91 \mathrm{E}-05$ & 0.181 & 0.709 \\
\hline & A101 & untreated $450 \mathrm{pv}$ river water & 0 & 0 & 98 & 485 & 12.3 & $1.14 \mathrm{E}-03$ & 0.306 & \\
\hline & & & 239 & 60.1 & 190 & 45.5 & 12.3 & $4.11 \mathrm{E}-05$ & 0.101 & \\
\hline & & & 935 & 188 & 241 & 30.6 & 10.3 & $1.98 \mathrm{E}-05$ & 0.066 & \\
\hline & & & 1566 & 285 & 1140 & 28.5 & 5.33 & $4.79 E-06$ & 0.041 & \\
\hline & & & 2754 & 348 & 1081 & 16.2 & 3.42 & $2.79 E-06$ & 0.071 & \\
\hline & & & 4221 & 395 & 1032 & 13.0 & 3.47 & $2.17 \mathrm{E}-06$ & 0.034 & 0.619 \\
\hline & A109 & untreated, 190 pv synthetic ground & 0 & 0 & 0 & 154 & 21.9 & & 0.674 & \\
\hline & & water & 240 & 49.8 & 1081 & 155 & 21.9 & $3.16 \mathrm{E}-05$ & 0.341 & \\
\hline & & & 1507 & 91.7 & 1032 & 74.5 & 10.0 & $1.60 \mathrm{E}-05$ & 0.077 & \\
\hline & & & 2759 & 141 & 958 & 45.7 & 9.42 & $9.74 \mathrm{E}-06$ & 0.121 & 1.213 \\
\hline \multirow{4}{*}{ 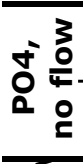 } & A105 & 47 mM PO4 treatment, no flow & 0 & 0 & 0 & & & & 0.000 & \\
\hline & & & 21.1 & 7.17 & 0 & 0.261 & 0.00 & & 0.0004 & 0.0004 \\
\hline & A108 & $47 \mathrm{mM}$ PO4 treatment, $4400 \mathrm{~h}$, no flow & 0 & 0 & 0 & 0.00 & 21.9 & & 0.00 & \\
\hline & & & 21.1 & 6.48 & 0 & 0.00 & 21.9 & & 0.00 & 0.00 \\
\hline \multirow{6}{*}{ 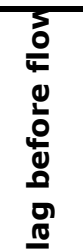 } & A103 & 47 mM PO4 treatment & 0 & 0 & 0 & 36.7 & 12.3 & & 0.0041 & \\
\hline & & $98 \mathrm{~h}$ lag before flow & 18.4 & 7.46 & 98.1 & 56.7 & 12.3 & $1.26 \mathrm{E}-04$ & 0.0497 & \\
\hline & & 450 pv river water & 355 & 49.1 & 190 & 3.01 & 12.3 & $-1.36 \mathrm{E}-05$ & 0.0261 & \\
\hline & & & 1052 & 138 & 241 & 2.42 & 5.33 & $-3.36 \mathrm{E}-06$ & 0.0434 & \\
\hline & & & 1683 & 206 & 1140 & 2.08 & 4.08 & $-4.90 E-07$ & 0.0423 & \\
\hline & & & 3070 & 249 & 1081 & 3.58 & 4.01 & $-1.11 \mathrm{E}-07$ & 0.041 & \\
\hline \multirow{3}{*}{$\begin{array}{l}\bar{c} \\
\infty \\
\sigma\end{array}$} & & & 4337 & 321 & 1032 & 6.90 & 4.86 & $5.52 \mathrm{E}-07$ & 0.032 & 0.239 \\
\hline & A102 & 47 mM PO4 treatment & 0 & 0 & 0 & 37.4 & 18.2 & & 0.0042 & \\
\hline & & 98 h lag before flow & 18 & 7.8 & 98.1 & 24.0 & 18.2 & 1.67E-05 & 0.0066 & 0.081 \\
\hline \multirow{5}{*}{ 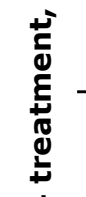 } & & 214 pv high U groundwater & 356 & 51.2 & 190 & 6.06 & 13.9 & $-1.16 \mathrm{E}-05$ & $* * *$ & \\
\hline & & & 1052 & 143 & 241 & 51.0 & 76.5 & $-3.00 E-05$ & $* * *$ & \\
\hline & A104 & $8 \mathrm{mM}$ PO4 treatment & 0 & 0 & 0 & 0.717 & 0 & & 0.0001 & \\
\hline & & $98 \mathrm{~h}$ lag before flow & 18.4 & 6.55 & 98.1 & 28.2 & 18.2 & $3.44 \mathrm{E}-05$ & 0.0472 & \\
\hline & & 214 pv high U groundwater & 337 & 42 & 190 & 3.28 & 13.9 & $-1.87 E-05$ & 0.0029 & 0.053 \\
\hline \multirow{2}{*}{ ষ̀ } & & & 1034 & 117 & 241 & 50.8 & 90.0 & $-5.48 \mathrm{E}-05$ & $* * *$ & \\
\hline & & & 1664 & 175 & 1140 & & 48.4 & & $* * *$ & \\
\hline
\end{tabular}

* positive release rate means $U$ mass released from sediment during stop flow, negative release rate means $U$ consumed by sediment/PO4 ** $U$ mass eluted after stop flow event up until start of next stop flow event

$* * *$ high $U$-conc river water influent used, so effluent not indicative of $U$ leaching off sediment 
Table 4.3. (contd)

\begin{tabular}{|c|c|c|c|c|c|c|c|c|c|c|}
\hline & $\begin{array}{l}\text { exp. } \\
\#\end{array}$ & treatment & $\begin{array}{l}\exp \\
(h)\end{array}$ & $\begin{array}{l}\text { exp. } \\
\text { pore vol }\end{array}$ & $\begin{array}{l}\text { stop } \\
\text { flow } \\
\text { (h) }\end{array}$ & $\begin{array}{c}\text { U peak } \\
\text { conc after } \\
\text { stop }(\mathrm{ug} / \mathrm{L})\end{array}$ & $\begin{array}{c}\text { U baseline } \\
\text { conc* } \\
\text { (ug/L) }\end{array}$ & $\begin{array}{c}\text { release } \\
\text { rate* } \\
(\mathbf{u g} / \mathbf{g} / \mathbf{h})\end{array}$ & $\begin{array}{l}\text { U mass** } \\
\text { eluted each } \\
\text { stop }(u g / g)\end{array}$ & $\begin{array}{r}\text { U mass } \\
\text { total eff } \\
(\mathrm{ug} / \mathrm{g})\end{array}$ \\
\hline \multirow{19}{*}{ 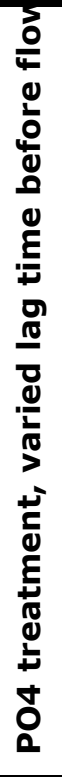 } & A117 & 47 mM PO4 treatment, $19 \mathrm{~h}$ stop flow & 0 & 0 & 0 & 42.1 & 21.9 & & 0.004 & \\
\hline & & 53 pv synthetic groundwater & 39 & 10.4 & 19.7 & 68.0 & 21.9 & $6.28 \mathrm{E}-04$ & & \\
\hline & & & 234 & 52.6 & 19.7 & 158 & 21.9 & $1.85 \mathrm{E}-03$ & 0.481 & 0.481 \\
\hline & A118 & $47 \mathrm{mM}$ PO4 treatment, $286 \mathrm{~h}$ stop flow & 0 & 0 & 0 & 17.5 & 21.9 & & 0.004 & \\
\hline & & 65 pv synthetic groundwater & 568 & 12.2 & 287 & 15.5 & 21.9 & $-5.46 \mathrm{E}-06$ & & \\
\hline & & & 568 & 12.2 & 287 & 161 & 21.9 & $1.18 \mathrm{E}-04$ & 0.634 & 0.638 \\
\hline & A119 & 47 mM PO4 treatment, 286 h stop flow & 0 & 0 & 0 & 15.4 & 21.9 & & 0.004 & \\
\hline & & 118 pv low U real groundwater & 568 & 15.9 & 287 & 14.9 & 21.9 & $-5.90 \mathrm{E}-06$ & & \\
\hline & & & 568 & 12.2 & 287 & 145 & 21.9 & $1.03 \mathrm{E}-04$ & 0.727 & 0.731 \\
\hline & A106 & $47 \mathrm{mM}$ PO4 treatment, $573 \mathrm{~h}$ stop flow & 0 & 0 & 0 & & & & 0 & \\
\hline & & $150 \mathrm{pv}$ synthetic groundwater & 18.4 & 7.5 & 572 & 0 & 21.5 & $-9.64 \mathrm{E}-06$ & 0.375 & \\
\hline & & & 813 & 41.8 & 1081 & 49.3 & 21.5 & $6.60 \mathrm{E}-06$ & 0.214 & \\
\hline & & & 813 & 41.8 & 1081 & 93.5 & 21.5 & $1.71 \mathrm{E}-05$ & & \\
\hline & & & 2080 & 91.7 & 1032 & 7.90 & 9.31 & $-3.51 \mathrm{E}-07$ & 0.055 & 0.644 \\
\hline & A107 & 47 mM PO4 treatment, 1915 h stop & 0 & 0 & 0 & & & & 0.001 & \\
\hline & & flow, 150 pv synthetic groundwater & 18.8 & 6.48 & 1894 & 0.32 & 21.8 & $-3.43 E-06$ & 0.186 & \\
\hline & & & 18.8 & 6.48 & 1894 & 30.8 & 21.8 & $1.42 \mathrm{E}-06$ & & \\
\hline & & & 2101 & 62.4 & 1032 & 4.63 & 21.8 & $-5.04 \mathrm{E}-06$ & 0.077 & \\
\hline & & & 3349 & 115 & 958 & 6.59 & 10.5 & $-1.23 \mathrm{E}-06$ & 0.136 & 0.400 \\
\hline \multirow{6}{*}{$\begin{array}{l}0 \\
\pm \\
0 \\
0\end{array}$} & A112 & $3000 \mathrm{ppm}$ xanthan treatment, $953 \mathrm{~h}$ & 0 & 0 & 0 & 107 & 21.9 & & 0.080 & \\
\hline & & stop flow, 62 pv synthetic groundwater & 972 & 14 & 954 & 110 & 21.9 & & 0.668 & 0.748 \\
\hline & A111 & 47 mM PO4 + 3000 ppm xanthan & 0 & 0 & 0 & 0 & 21.9 & & & \\
\hline & & treatment, no flow & 18.6 & 7.8 & 0 & 15.9 & 21.9 & & 0.076 & 0.076 \\
\hline & A110 & 47 mM PO4 + 3000 ppm xanthan & 0 & 0 & 0 & 98.1 & 21.9 & & 0.062 & \\
\hline & & $\begin{array}{l}\text { treatment, } 1100 \text { h stop flow, } \\
63 \text { pv synthetic groundwater }\end{array}$ & 1140 & 15.1 & 1102 & 0 & 6.19 & $-1.91 \mathrm{E}-06$ & 0.083 & 0.145 \\
\hline
\end{tabular}


Nearly all uranium leaching rates for phosphate treatments were less than those for untreated sediments at less than $1000 \mathrm{~h}$ (Figure 4.4a and c), but at times approaching $5000 \mathrm{~h}$, the uranium leaching rate increased to near that of the untreated sediment. These leaching rates do not reflect total leached uranium mass, as the comparison of leaching rates for untreated to a single phosphate-treated sediment (Figure $4.4 \mathrm{~b}$ and d) may be similar at large time, but a significant mass $(61 \%)$ of uranium is not eluting for the phosphate-treated sediment (Figure 4.3c). Comparison of leached uranium mass for all phosphate experiments (Figure $4.1 \mathrm{~b}$ ) show $10 \%$ to $95 \%$ less uranium leached mass for early time periods $(<500 \mathrm{~h})$, but after longer periods of time (or experiment end), the difference in leached mass for phosphate-treated and untreated sediments is less.
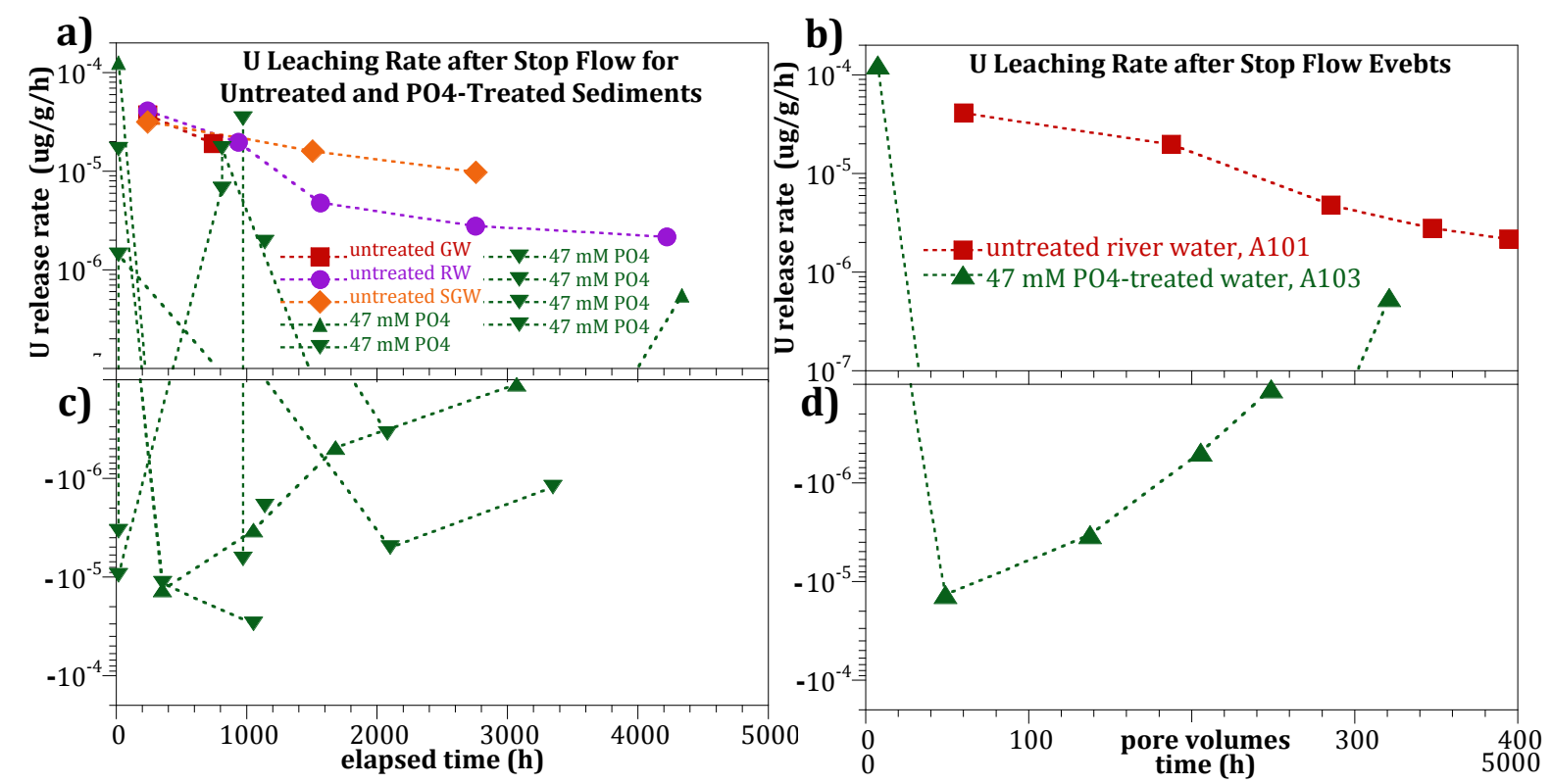

Figure 4.4. Uranium Leaching Rates from Untreated and $\mathrm{PO}_{4}$-Treated Sediments: (a) and (c) All Experiments (a) and (c), and Untreated and $\mathrm{PO}_{4}$-Treated Sediments with River Water Injection (b) and (d)

\subsection{Influence of Phosphate/Sediment Reaction Time on Uranium Leaching}

It is hypothesized that greater contact time between phosphate, sediment, and uranium phases before advection of river or groundwater will result in less uranium leaching. This may be caused by the ripening of phosphate precipitates from amorphous to crystalline, then a progression from di- to octacalcium phosphate and finally hydroxyapatite (Sumner 2000) over months to years, with lower phosphate solubility. Uranium may form uranium-phosphate precipitates or surface uranium phases may be coated by non-uranium phosphate precipitates.

Experiments conducted with a lag time between the phosphate treatment and advective flow (of river, groundwater, or synthetic groundwater) ranging from $19 \mathrm{~h}$ to $4400 \mathrm{~h}$ showed a weak trend of decreased uranium in effluent (Figure 4.5a) and a slightly better trend of increasing immobile uranium (Figure 4.5b). Some of the scatter in the trend may be accounted for by differences in amount of advective flow (varied 
from no flow to 450 pore volumes of water), difference in phosphate concentration used for treatment, and differing water used for advection. Experiments that used synthetic groundwater (light green diamonds in Figure 4.5a) had higher effluent uranium relative to experiments that used river water or real groundwater (dark green, Figure 4.5a). However, there was no difference in the $8 \mathrm{M} \mathrm{HNO}_{3}$-extractable uranium for synthetic groundwater compared with experiments that were leached with river water or groundwater (Figure 4.5b). Experiments that included xanthan with phosphate treatment (purple triangles, Figure 4.5) performed best, with the lowest effluent uranium and the highest immobile uranium (described further in Section 4.5).
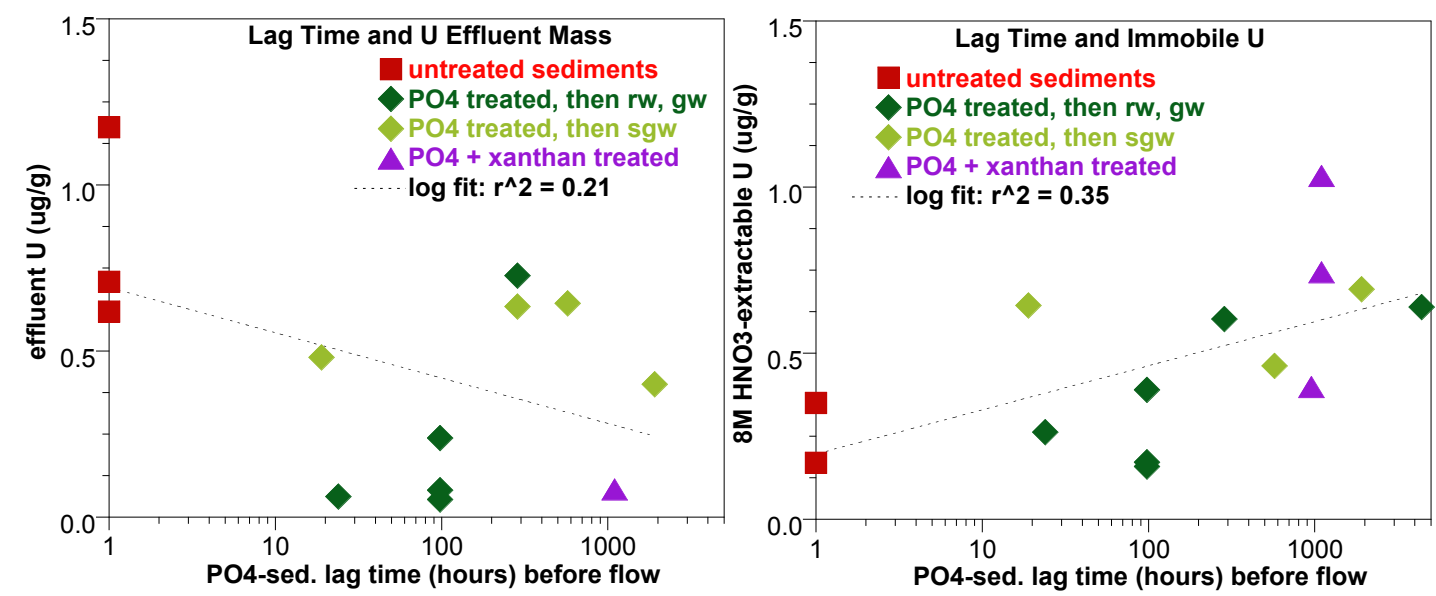

Figure 4.5. Influence of Sediment- $\mathrm{PO}_{4}$ Contact Time (i.e., lag time) and (a) Total Leached Uranium, or (b) Immobile Uranium, as Defined by Uranium Extracted from Sediment by $8 \mathrm{M} \mathrm{HNO}_{3}$

\subsection{Phosphate Concentration and Uranium Leaching}

The influence of phosphate concentration on uranium was evaluated in two experiments in which 47-mM (A102) and 8-mM (A104) phosphate solutions were used to treat the sediment, followed by injection of uranium-laden natural groundwater in 214 pore volumes over $1100 \mathrm{~h}$. While a long reaction time (i.e., hundreds of hours) lead to less uranium leaching (Figure 4.5), a short 98-h reaction time was used for this comparison. Both $8-\mathrm{mM}$ and $47-\mathrm{mM}$ phosphate-treated columns leached $80 \%$ lower mass of uranium initially $(<400 \mathrm{~h}$ ) compared to untreated sediment (Figure 4.6a), with no difference between the amount of phosphate used in the sediment. By 143 pore volumes $(750 \mathrm{~h})$, both phosphate-treated sediment columns released the same amount of uranium as the untreated sediment, so effectiveness was limited likely due to the short 98 -h reaction time. Phosphate extractions conducted after uranium leaching showed little remaining phosphate $(0.015 \mathrm{mg} / \mathrm{g}$ for $47-\mathrm{mM}$ treatment, $0.013 \mathrm{mg} / \mathrm{g}$ for $8-\mathrm{mM}$ treatment; Table 4.1) relative to phosphate-treated sediments that received no flow $\left(0.18-\mathrm{mg} \mathrm{PO}_{4} / \mathrm{g}\right.$ sediment $)$. The 8-mM phosphate treatment column leached less uranium $(0.047 \mu \mathrm{g} / \mathrm{g}$, Table 4.1$)$ compared to the $47-\mathrm{mM}$ phosphate-treatment column $(0.081 \mu \mathrm{g} / \mathrm{g})$.

Uranium extractions conducted after leaching experiments showed no difference in the immobile uranium fraction (i.e., $8 \mathrm{M} \mathrm{HNO}_{3}$ in green, Figure 4.6b) between the two treatments and compared to the untreated sediment A100. Although these experiments were not effective, other 47-mM phosphate 
treatments with longer phosphate-sediment reaction times were more effective (Figure 4.5 and Figure 4.2) in terms of lower leached uranium and greater immobile uranium remaining associated with the sediment.
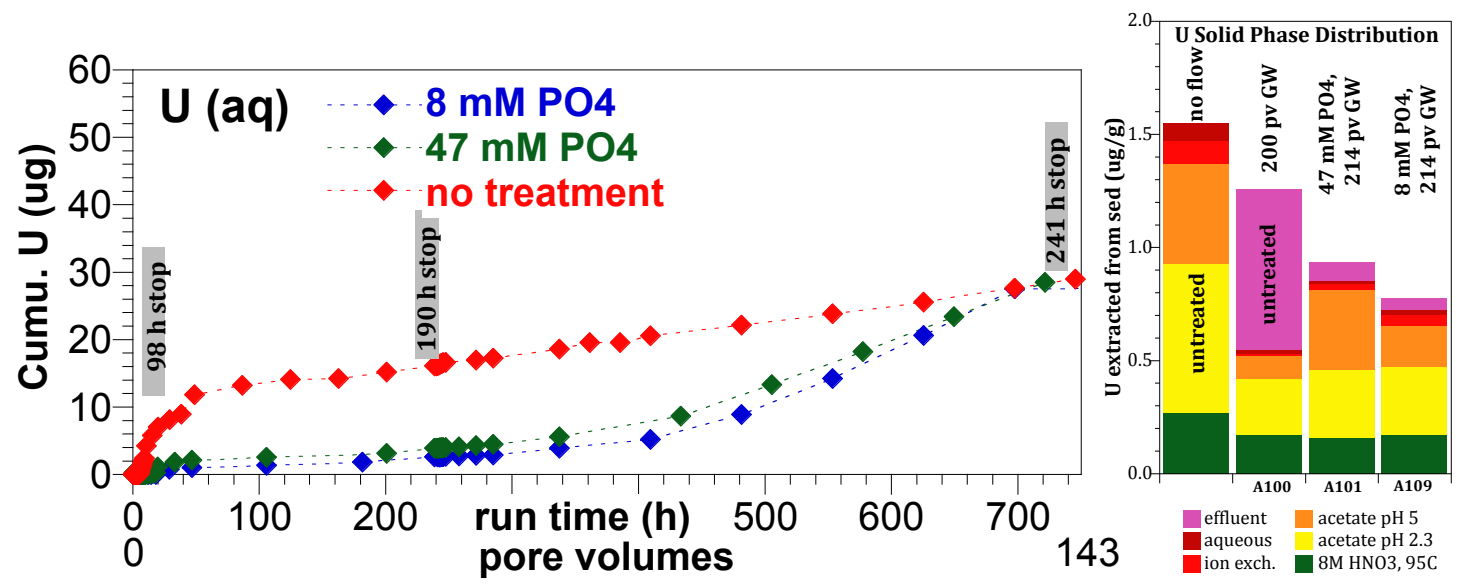

Figure 4.6. Uranium Cumulative Leached Mass from Differing Phosphate Treatment (a) and Solid Phase Distributions after Leaching (b)

A previous investigation of differing phosphate treatment concentration showed a more limited effectiveness of lower phosphate concentration (Shi et al. 2009). In that study, $1 \mathrm{mM}$ or $50 \mathrm{mM}$ phosphate was batch reacted with the sediment (not injected through the sediment as was done in this study) and in addition, calcium was also mixed with the sediment $\left(\mathrm{Ca}^{2+}\right.$ was not added in this study). The sediment used was from the Hanford 200 Area BX Tank Farm and contained a high uranium concentration $(0.47 \mu \mathrm{mol} \mathrm{U} / \mathrm{g}$ or $112 \mu \mathrm{g} \mathrm{U} / \mathrm{g})$ or about 100 times as much as 300 Area sediments. Results of that study showed that $1-\mathrm{mM}$ phosphate treatment was ineffective, close to untreated sediment in terms of leaching concentration (by 200 pore volumes) whereas the $50-\mathrm{mM}$ phosphate treatment was demonstrated to be effective at reducing uranium leaching. Results in that study indicate decreased uranium leaching was caused by uranium adsorption to sediment and possible formation of uraniumphosphate precipitates for the 50-mM phosphate treatment. Even the 50-mM phosphate-treated column in that study showed positive uranium peaks at stop flow events, compared to negative peaks in this study (Figure 4.3b). Those differences are likely caused by the $100 \times$ higher uranium concentration on the sediment. The 1-mM phosphate treatment contains insufficient phosphate to sequester uranium in that study. The $0.47-\mu \mathrm{mol} \mathrm{U} / \mathrm{g}(112-\mu \mathrm{g} \mathrm{U} / \mathrm{g})$ is equivalent to $4.6 \mathrm{mmol} \mathrm{U} / \mathrm{L}$, exceeding the $1 \mathrm{mM}$ of available phosphate. Autunite $\left[\mathrm{Ca}\left(\mathrm{UO}_{2}\right)_{2}\left(\mathrm{PO}_{4}\right)_{2}\right]$ would have $\mathrm{P}: \mathrm{U}$ of $1: 1$, so only $22 \%$ of the uranium could precipitate with the 1-mM phosphate.

\subsection{Phosphate Delivery by Water Saturated Injection with Xanthan}

Maintaining phosphate solution for weeks to months, uranium-contaminated field sediment could be accomplished by phosphate solution infiltration (see Section 4.5) or use of a high viscosity fluid (xanthan) that moves slowly compared with water. Shear-thinning fluids such as xanthan can be designed such that they have a viscosity suitable for injection at moderate pressure when the injection flow rate is high. When the injection is stopped (i.e., shear rate is reduced), the viscosity increases significantly and the native groundwater, either bypassing the injection zone or very slowly displaces and invades the injection 
zone, then over time, biodegrade. Although xanthan use is to change the physicochemical properties (i.e., viscosity) of the phosphate injection solution, experiments were needed to characterize whether xanthan: a) changes uranium leaching, b) influenced phosphate precipitation rate, and c) maintains high viscosity in actual groundwater in contact with sediment.

\subsubsection{Xanthan Influence on Uranium Leaching}

The geochemical influence of xanthan on uranium adsorption, uranium aqueous complexation, and phosphate precipitation is described in detail elsewhere (Szecsody et al. 2011) and summarized here. Physiochemical properties of xanthan and 2-D laboratory evaluation of xanthan stability in sediment are also described in that report. In this study, xanthan was added to some $47-\mathrm{mM}$ phosphate treatments in stop flow columns and compared with phosphate treatments.

Injection of 3000 ppm xanthan (with no phosphate, Figure 4.7a, in purple) did result in advection of uranium from the sediment $(0.67 \mu \mathrm{g} / \mathrm{g})$, but less than untreated sediment $(1.17 \mu \mathrm{g} / \mathrm{g})$. This suggests that uranium may not complex with xanthan. Xanthan is a long helical chain microbially produced polymer of glucose (i.e., sugar) with side chains that contain the trisaccharide sequences of mannose/glucuronicacid/mannose attached to other glucose residue in the backbone (Seright and Herrici 1990). Xanthan has been modeled with a length of 0.6 to $1.5 \mu \mathrm{m}$, but in saline solutions, the molecule compresses to 0.1 to $0.4 \mu \mathrm{m}$ in length. The change in length of this worm-like (helical) molecule and configuration is dependent on salinity, temperature, and sample history. The dependence of xanthan viscosity on the salt concentration is critical for groundwater injection, as there are both ions in solution and $\sim 100 \times$ times more ions adsorbed on sediment surfaces. There are also cross-links between portions of the xanthan molecule, which changes with salinity change.

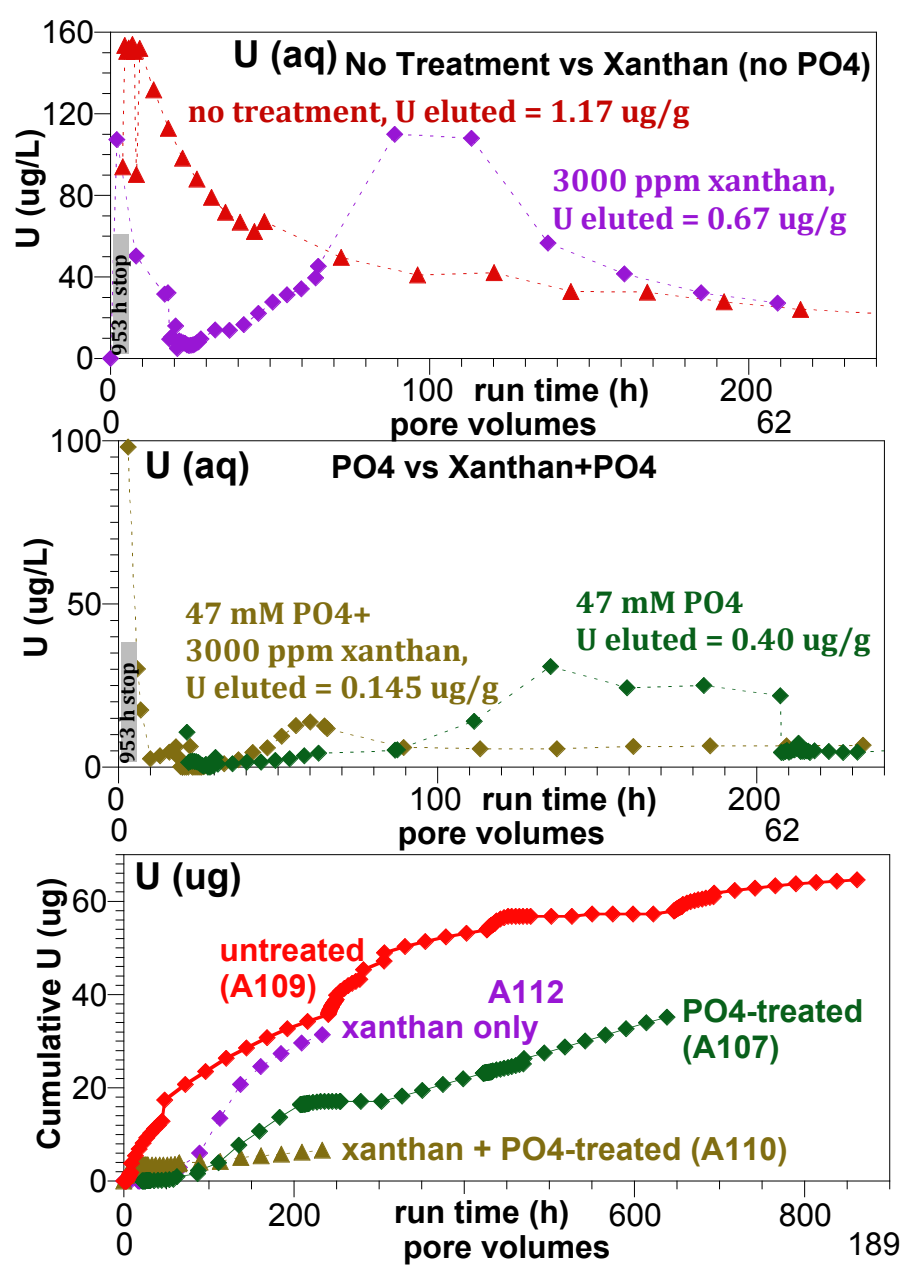

Figure 4.7. Comparison of Uranium Leaching for (a) No Treatment and Xanthan (no $\left.\mathrm{PO}_{4}\right)$, (b) $\mathrm{PO}_{4}$ and $\mathrm{PO}_{4}{ }^{+}$Xanthan, and (c) Cumulative Uranium for Untreated and Treated 
Table 4.4. Uranium Adsorption to Sediment in the Presence of Xanthan

\begin{tabular}{|c|c|c|c|}
\hline $\begin{array}{c}\text { Xanthan } \\
\text { (ppm) }\end{array}$ & $\begin{array}{c}\text { Kd } \\
10 \mathrm{ug} / \mathrm{L} \mathrm{U} \\
(\mathrm{mL} / \mathrm{g}) \\
\end{array}$ & $\begin{array}{c}\mathrm{Kd} \\
100 \mathrm{ug} / \mathrm{L} \mathrm{U} \\
(\mathrm{mL} / \mathrm{g})\end{array}$ & $\begin{array}{c}\text { Kd } \\
1000 \mathrm{ug} / \mathrm{L} U \\
(\mathrm{~mL} / \mathrm{g})\end{array}$ \\
\hline 0 & -- & 2.33 & 1.42 \\
\hline 800 & 6.29 & 2.70 & 4.51 \\
\hline 1500 & 7.72 & 3.74 & 2.82 \\
\hline 2000 & 9.51 & 6.71 & 5.19 \\
\hline
\end{tabular}

Batch U-sediment adsorption experiments were conducted at 10,100, and $1000 \mathrm{ppb}$ uranium, with xanthan concentrations of $0,800,1500$, and $2000 \mathrm{ppm}$. There was a trend of 3 times higher $\mathrm{K}_{\mathrm{d}}$ for uranium adsorption for higher xanthan concentration (Table 4.4).

The main purpose of xanthan addition would be to maintain phosphate solution contact with

unsaturated sediments in Hanford 300 Area due to the high viscosity. Batch experiments were conducted in the previous study (Szecsody et al. 2011) that showed the presence of xanthan did not change the rate of removal of phosphate from solution (from phosphate adsorption and precipitation) and also did not appear to alter the stability of uranium surface phases (Figure 4.8). Based on a phosphate adsorption isotherm to a similar Hanford sediment (Szecsody et al. 2009), at $50 \mathrm{mM} \mathrm{PO}_{4}$ and a low sediment/water

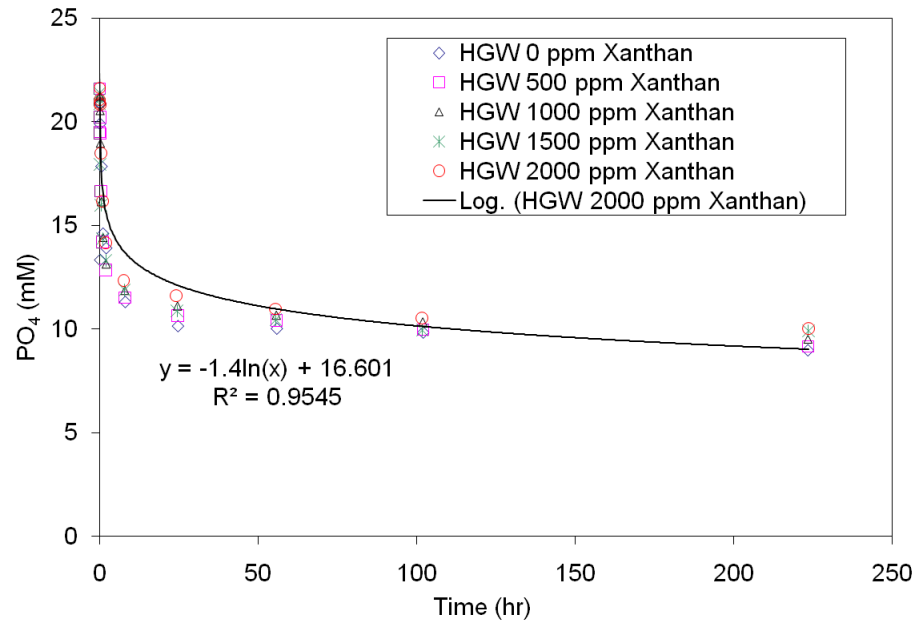

Figure 4.8. Influence of Xanthan Gum on CalciumPhosphate Precipitation Rate in Groundwater ratio in these experiments, nearly all of phosphate removal from solution was the result of precipitation. In solutions with xanthan concentrations ranged from 0 to 2000 ppm xanthan, phosphate precipitated at similar rates.

Comparison of uranium leaching in a phosphate-only treatment (Figure 4.7b, green) with a 1900-h reaction time to xanthan/phosphate treatment (Figure 4.7b, brown) with a 1100-h reaction time show three times less uranium leaching with the addition of xanthan. The cause of this effect is not known, but it is hypothesized that the high viscosity of the phosphateladen xanthan solution may force the phosphate into sediment grain microfractures. This is similar to a known larger-scale phenomena where xanthan (or other high viscosity fluids) will advect into low-K zones that are water-saturated. Cumulative uranium leaching (Figure 4.7c) shows that the phosphate solution with xanthan leaches less uranium than the phosphate only treatment. Only two xanthan and phosphate column experiments were conducted, but both showed the least amount of uranium leaching and greatest increase in immobile uranium (Figure 4.5 and Figure 4.2) compared with phosphate-only treatments. The significant increase in the nonlabile (immobile) uranium phase (Figure 4.9) for phosphate/xanthan treatments (average $0.89 \pm 0.21 \mu \mathrm{g} / \mathrm{g}$ ) compared to phosphate treatments $(0.45 \pm 0.21 \mu \mathrm{g} / \mathrm{g}$, untreated sediment $0.26 \pm 0.08)$ may correspond to high phosphate precipitate on the surface, as $0.28-\mathrm{mg} \mathrm{PO}_{4} / \mathrm{g}$ sediment was measured after phosphatexanthan treatment (no flow) compared with $0.16-0.20 \mathrm{mg} / \mathrm{g}$ for phosphate treatment alone (no flow, Table 4.1).

The uranium leaching from xanthan or xanthan/phosphate-treated sediment columns is different from leaching observed for untreated or phosphate-treated columns. The xanthan-treated sediment columns 
show bimodal uranium leaching, with an initial peak (similar to untreated sediment, but lower concentration) followed by a later uranium peak at 50-150 h (Figure 4.7a, b). Xanthan breaks down and washed out of the columns within days to weeks, so the second peak may represent uranium advection from sediment surfaces after breakdown. The uranium peak concentration for xanthan/phosphate treatments $(107,110 \mu \mathrm{g} / \mathrm{L})$ was lower than untreated sediment (155 $\mu \mathrm{g} / \mathrm{L}$, Table 4.2$)$, but higher than the phosphate-treated sediment ( 15 to $68 \mu \mathrm{g} / \mathrm{L}$ ) that had $1915 \mathrm{~h}$ of reaction time before advection (A107, Table 4.2, peak $31 \mu \mathrm{g} / \mathrm{L}$ ). Uranium release rates for xanthan-phosphatetreated sediments were calculated at stop flow events (Table 4.2). This result was similar to the phosphate only treatment.

\subsubsection{Xanthan-Phosphate Addition to Sediment: Influence on Fluid Properties}

To evaluate the injection behavior of the delivery system, the influence of phosphate on the rheological property of xanthan solution was measured at xanthan concentrations of 1500, 2000, and $3000 \mathrm{ppm}$ (Figure 4.10). The added phosphate concentration for these experiments was $47 \mathrm{mM}$. The presence of phosphate lowered the dynamic viscosity and the degree of shear thinning of the solutions. When the xanthan concentration was higher, the influence of the phosphate was relatively lower. The $3000 \mathrm{ppm}$ xanthan solution with $47 \mathrm{mM}$ phosphate had viscosity higher than $2000 \mathrm{cP}$ at shear rate of $0.3 \mathrm{~s}^{-1}$.

In order to evaluate the persistence of the injected xanthan solution in the formation, one set of batch tests was conducted (Figure 4.11). This experiment tested the influence of polymer concentration on viscosity degradation in the presence of Hanford sediment, using solutions at 600 to $2000 \mathrm{mg} / \mathrm{L}$ xanthan $\left(\right.$ at $17^{\circ} \mathrm{C}$ ). The solution-sediment systems were stirred once a day. Samples were taken for rheology measurement at $0.25,168,336$, and $504 \mathrm{~h}$. The xanthan solution and sediment mixtures were settled to separate the sediment grains from the solution before rheology measurement. The viscosity for the solutions mixed with sediments dropped more than $65 \%$ after $168 \mathrm{~h}$ ( 1 week), and more than $95 \%$ after $336 \mathrm{~h}$

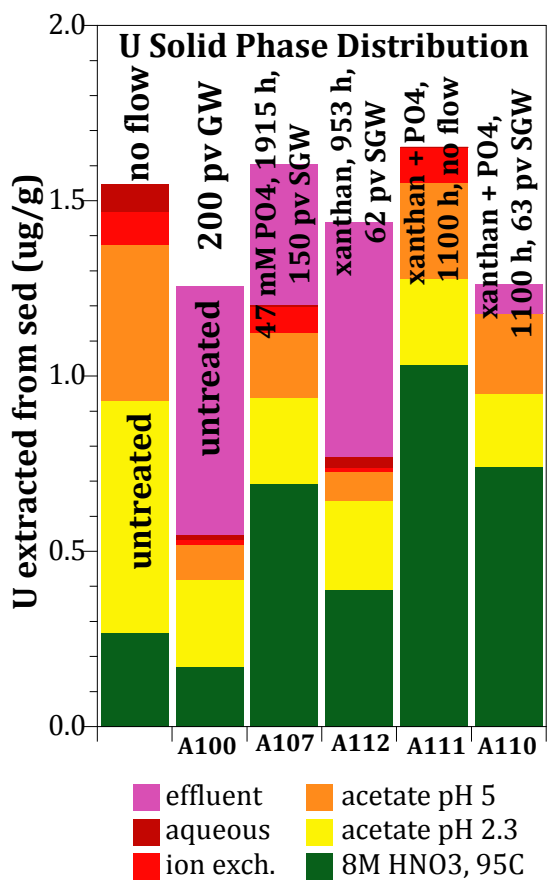

Figure 4.9. Uranium Extraction Comparison of Untreated, Phosphate Treatment, and Phosphate/Xanthan Treatment

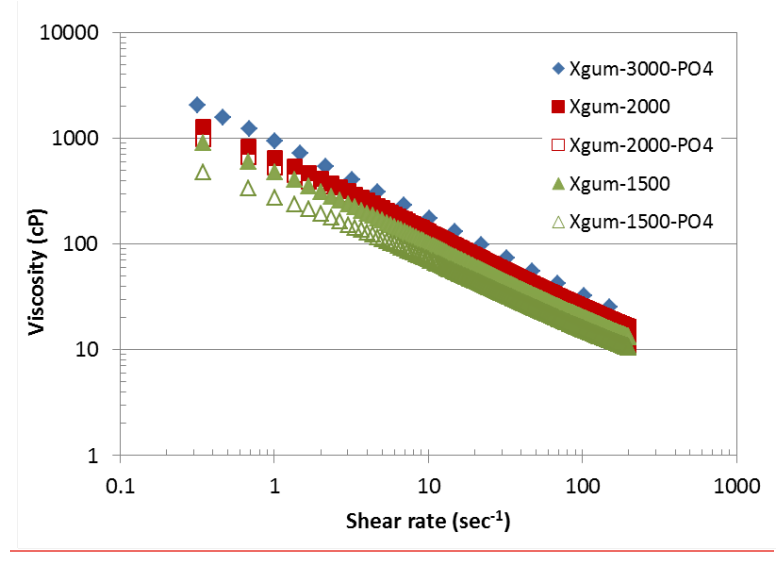

Figure 4.10. $\mathrm{PO}_{4}$ Influence on Xanthan Solution Rheology (47 $\mathrm{mM} \mathrm{PO}_{4}$ was used) 
(2 weeks, Figure 4.11a). After $168 \mathrm{~h}$ of degradation, the solutions still exhibited shear-thinning prosperity; but after $336 \mathrm{~h}$ of degradation, shear-thinning behavior was not observed. Exponential regression was applied to the viscosity values to evaluate the xanthan degradation rate. The fitting equations are shown in Figure 5.14a. The solution with higher xanthan concentration showed high degradation rate. In the control test where no sediment was added, the solution viscosity kept its initial value in the testing period.
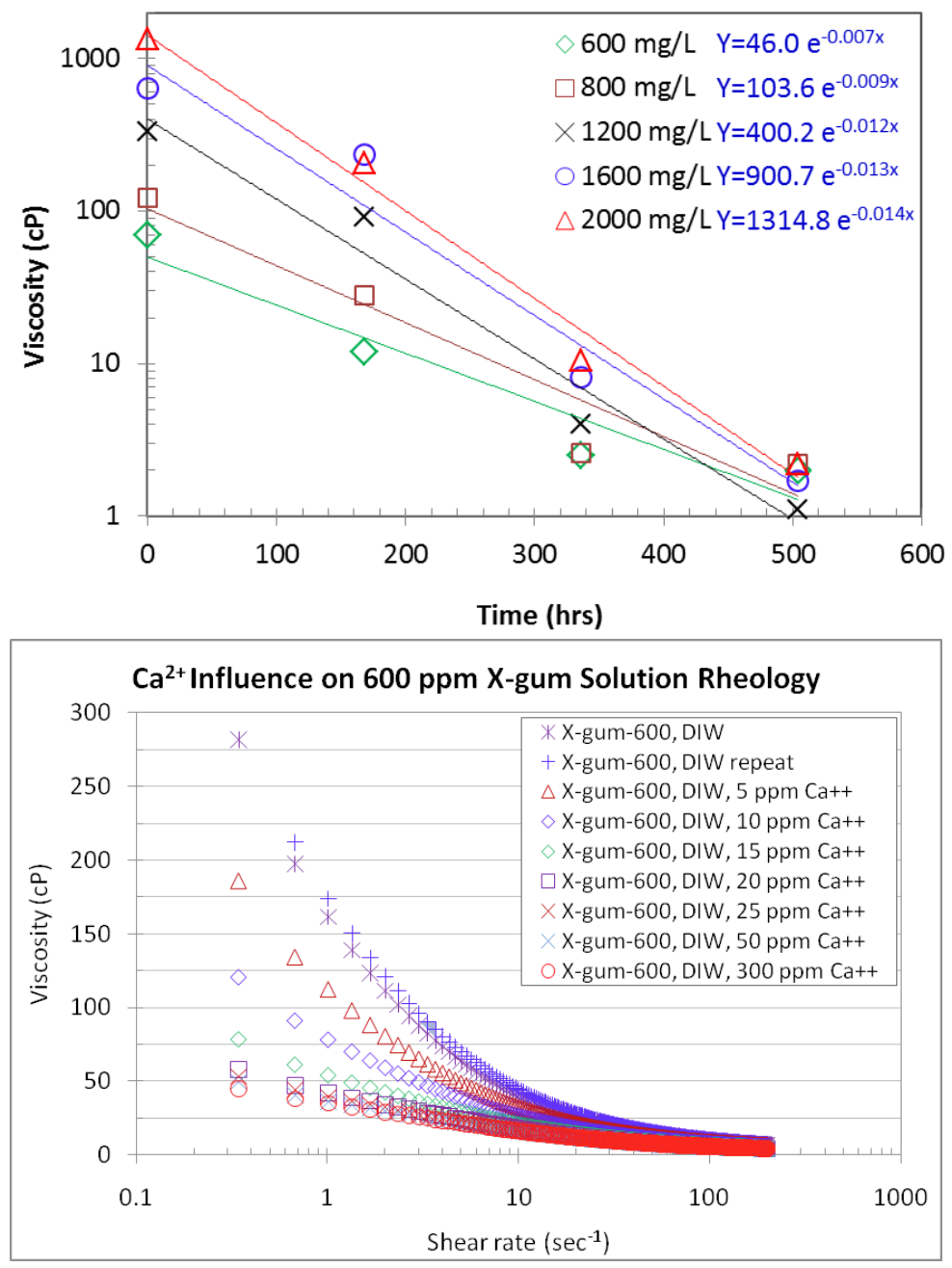

Figure 4.11. Xanthan Concentration Influence on Viscosity Degradation Rate (a) at $0.3 \mathrm{~s}^{-1}$ Shear Rate and $47 \mathrm{mM} \mathrm{PO}_{4}$, and (b) Xanthan Viscosity Change with Increasing $\mathrm{CaCl}_{2}$ Concentration
Xanthan viscosity was also measured to be slightly higher $(1.2 \times)$ at $17^{\circ} \mathrm{C}$ versus $25^{\circ} \mathrm{C}$ in the previous study. Xanthan viscosity was greatest at $\mathrm{pH} 6$ to 10 (highest at $\mathrm{pH} 9$ ), with a substantial decrease in acidic and alkaline water. The increase in salinity dramatically decreased xanthan viscosity (Figure 4.11b). The use of tap water decreased xanthan viscosity 10 fold relative to deionized water. Both of these immediate ionic strength effects are likely caused by change in xanthan molecular configuration (i.e., compressing at higher ionic strength). The average xanthan degradation half-life in oxic water was $52.1 \mathrm{~h}$ (Figure 4.12), and was slightly more rapid at higher xanthan concentration. The decrease in xanthan viscosity over three weeks in anaerobic water (deg. half life 39 h, Figure 4.12 open red circles) and aerobic water $(42 \mathrm{~h}$, red circles, both at $1600 \mathrm{ppm}$ xanthan) is indirect evidence that suggests the change in viscosity is abiotically controlled.

Biodegradation should be significantly different in the presence of oxygen (i.e., anaerobic

respiration), in contrast to anaerobic water in which different a somewhat different consortium of microbes (anaerobic or facultative bacteria) in the sediment may be able to degrade the xanthan, likely at a different rate.

Experiments were conducted in the previous study (Szecsody et al. 2011) to determine if xanthan were being biodegraded and/or abiotically degraded or molecules reconfigured, which resulted in the reduced observed viscosity. 
Biodegradation would be significantly slower in autoclaved sediment (designed to kill microbes), whereas abiotic degradation should not change with autoclaving. In addition, biodegradation would not be instantaneous, but occur within tens to hundreds of hours.

It was hypothesized that natural microbes in Hanford sediment $\left(\sim 10^{5}\right.$ to $10^{7}$ cells/g) could be utilizing the xanthan as a carbon source (glucose polymer). In addition, iron oxides on sediment could be abiotically degrading the xanthan, as it did not degrade in clean sand (see experiments described below). Column experiments were conducted with injection of $3000 \mathrm{ppm}$ xanthan and $47 \mathrm{mM}$ phosphate solution in groundwater into a) Hanford sediment, b) autoclaved Hanford sediment, and c) acid-washed, autoclaved Hanford sediment (Figure 4.13). These column studies are most representative of field conditions with the $(5.5 \mathrm{~g} / \mathrm{mL})$ high sediment/water ratio (i.e., high mineral phase and adsorbed ion concentrations relative to solution volume), compared with batch experiments with a low sediment/water ratio $(<1 \mathrm{~g} / \mathrm{mL}$ or 5 to 50 times less mineral phase/xanthan contact). Autoclaving to kill microbes (although the $125^{\circ} \mathrm{C}$ crystallized some amorphous iron oxides) resulted in a slight decrease in the xanthan degradation rate $(0.0173 / \mathrm{h}$ to $0.0124 / \mathrm{h})$, indirectly indicating microbes were not degrading the xanthan (Figure 4.13, black squares versus blue circles). The $0.5 \mathrm{M}-\mathrm{HCl}$ (15 minutes) treatment of the sediment before autoclaving removed some amorphous and crystalline iron oxides. Xanthan viscosity in the acid-washed, autoclaved Hanford sediment showed a dramatic decrease in the apparent xanthan degradation rate (i.e., $0.0173 / \mathrm{h}$ to $0.0023 / \mathrm{h}$ or $7.5 \times$ slower,

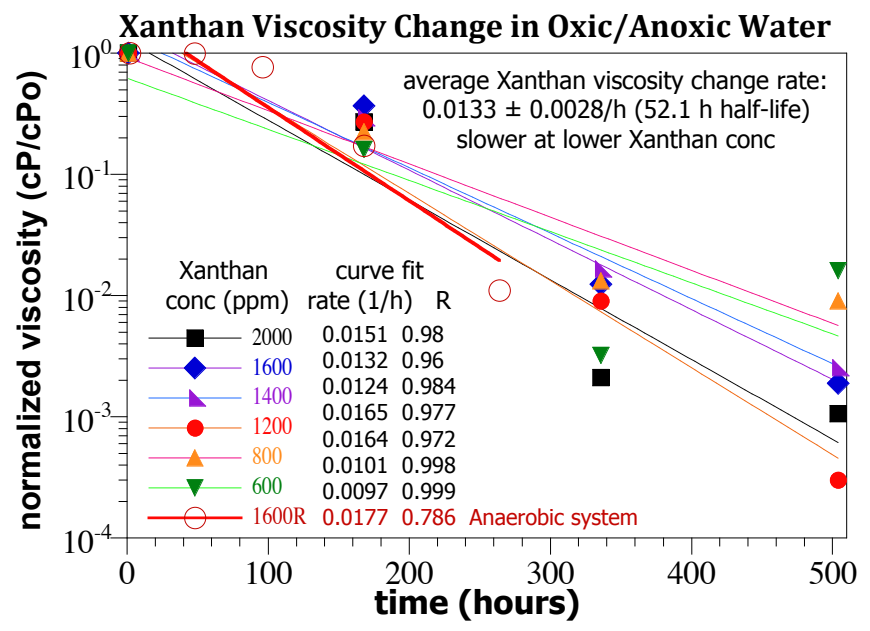

Figure 4.12. Xanthan Viscosity Decrease in the Presence of Hanford Sediment at Differing Xanthan Concentration

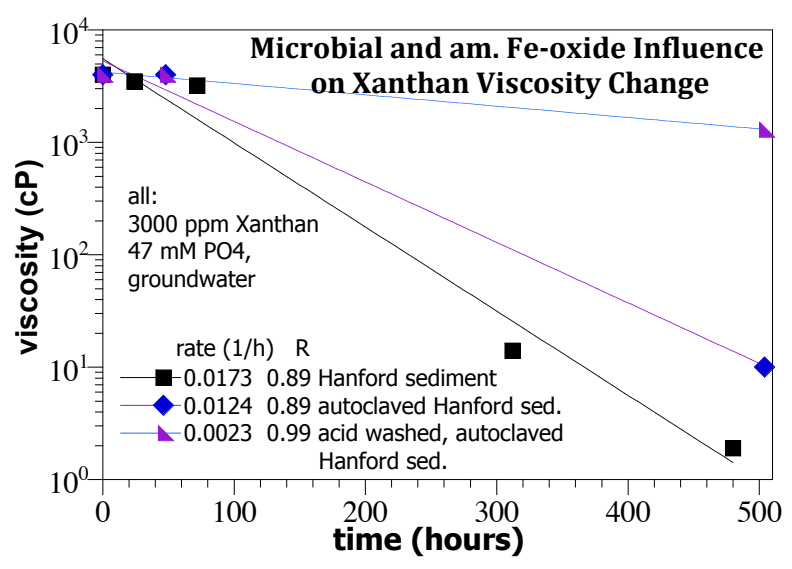

Figure 4.13. Xanthan Viscosity Decrease in the Presence of Hanford Sediment Influenced by Autoclaving and Acid Washing

Figure 4.13, purple triangles), indirectly indicating iron oxides (or other minerals dissolved in the weak acid treatment) may be controlling the rapid xanthan degradation. Xanthan viscosity did decrease at a more rapid rate at a higher sediment/water ratio, indicating that mineral surfaces or microbes associated with the sediment were controlling the rate. Further research is needed to identify whether xanthan is actually being degraded, and if so what are the primary variables controlling degradation are, or just being reconfigured by contact with specific mineral phases or microbes. 

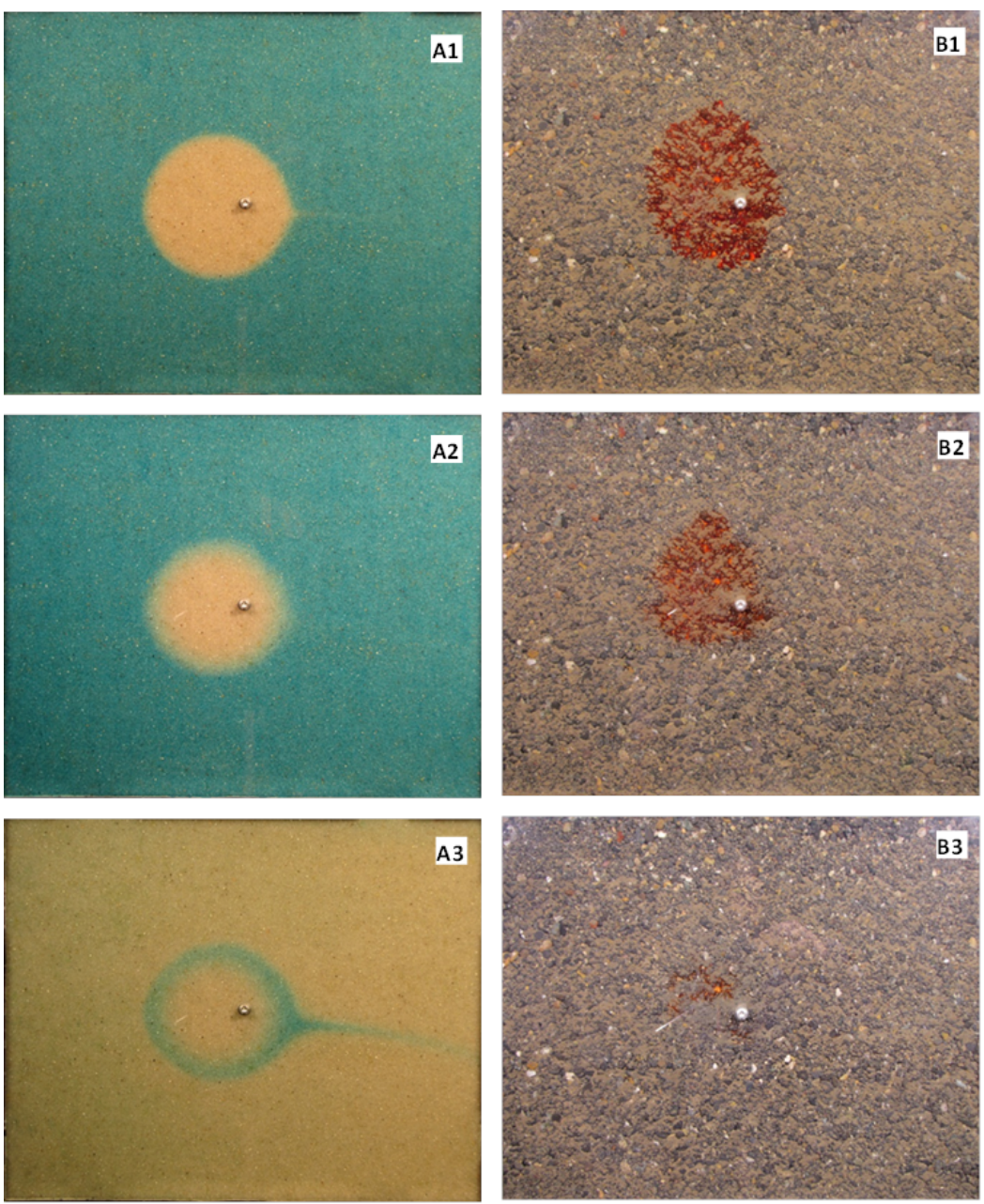

Figure 4.14. Distribution of Xanthan Solution in Sediments Injected into Sand (A1, A2, A3) and Hanford Sediment (B1, B2, B3) after 0 h, 10 days, and 14 days of Water Flushing
To validate the batch test observations that xanthan (and xanthan-phosphate) solutions degraded/reconfigured and lost viscosity in a time scale of weeks in contact with natural sediment, 2-D flow cells experiments were conducted to examine the persistence of injected xanthan solution in sediment formation under continuous flow conditions (Figure 4.14). The first test (FC-1) was conducted with a high purity sand (20/30 Accusand), and the second test (FC-2) was performed using a Hanford 300 Area infiltration site composite (Table 3.4). The xanthan solution was not dyed and water was dyed blue in FC-1, while the polymer solution was dyed with a red food dye at $100-\mathrm{mg} / \mathrm{L}$ concentration but water was not colored for FC-2. The influence of the dye on the rheology is negligible. The xanthan solutions were injected at the flow cell center $(x=20 \mathrm{~cm}$, $\mathrm{z}=20 \mathrm{~cm}$, lower left is 0,0$)$ at a concentration of $5,000 \mathrm{mg} / \mathrm{L}$ with a rate of $50 \mathrm{ml} / \mathrm{min}$ for 6 minutes. Water flow with a rate of

$0.20 \mathrm{~cm} / \mathrm{min}$ was applied to the left-hand side of the flow cell. The water level was kept at $\mathrm{z}=0.4 \mathrm{~m}$ (flow cell top). Water without dye was injected through the flow cell after 2 weeks flushing with blue-dyed water to observe changes inside the xanthan plume.

The injection of a 5000-mg/L xanthan solution into accusand in the flow cell displaced the blue-dye water and initially formed a spherical xanthan plume in the sand (A1 in Figure 4.14) due to the higher viscosity of the xanthan solution and homogeneous porosity in the sand. The stability of the plume over 14 days was the result of the high viscosity of the xanthan solution and little degradation. In contrast, a $5000-\mathrm{mg} / \mathrm{L}$ xanthan solution injection formed a somewhat irregular plume (B1, Figure 4.14) due to spatial variation in porosity. The xanthan plume remained fairly constant for 1 week in the sediment (B2), but degraded and washed away by 2 weeks (B3), indicating substantial viscosity reduction in the polymer solution. 
The persistence of xanthan solution in the Accusand for over 2 weeks and the degradation/advection of the same xanthan solution starting after a 10-day duration in the Hanford Site sediment was qualitatively consistent with batch experiment results. The observed results of xanthan stability in sediment of $<10$ days $(240 \mathrm{~h}$ ) would, therefore, imply limitation of the efficiency of phosphate emplacement, in spite of the geochemical advantages of phosphate injection with xanthan (compared with phosphate injection alone). Because of the difficulty in measuring xanthan and the multiple degradation products (glucose and shorter chain molecules or average molecular weight), it is not known whether the observed decrease in xanthan solution viscosity is caused by molecular reconfiguration (i.e., molecule compression in the presence of ions) or degradation.

\subsection{Phosphate Infiltration: Phosphate Distribution and Uranium Mobility}

A total of twenty-five 1.0 to 3.0 meter (3- to 10-ft) high 1-D infiltration columns were conducted to develop a polyphosphate solution infiltration strategy to precipitate phosphate at depth in the uranium contaminated smear zone in the Hanford 300 Area (Table 3.2). Experiments were specifically designed to quantify: a) phosphate retardation factor relative to an infiltrating tracer, b) influence of infiltration rate on phosphate retardation, c) optimizing phosphate precipitate deposition at depth by combinations of phosphate and water pulses, d) influence of physical heterogeneity on phosphate precipitation, and e) influence of phosphate infiltration on uranium initial desorption and labile fraction in sediment. These 2-in.-diameter columns were packed with sediment from the Hanford 300 Area vadose zone (infiltration site) with a grain size distribution representative of the polyphosphate field site (see experimental section). Because the clay, silt, sand, and gravel fractions are the same as the field system (although large gravel was replaced with pea gravel), uranium $\mathrm{K}_{\mathrm{d}}$ values obtained should be representative of the field. Most infiltration columns were packed with a homogeneous grain size distribution (infiltration site composite) with a uranium distribution in the bottom third of the system as aqueous/adsorbed uranium or a uranium-carbonate precipitate mixed with the sediment (approximating low uranium in shallow sediment and high uranium in the smear zone at depth). The 3-m (10-ft) high columns were approaching field scale, where the smear zone is located at a $22-$ to $30-\mathrm{ft}$ depth). Two columns were packed with a heterogeneous grain size distribution with the top two-thirds of the system with coarser sediment (infiltration site composite) and the bottom third of the system packed with a finer sediment, which approximated conditions found at the 300 Area infiltration site. An optimum phosphate precipitate distribution in the sediment would maximize phosphate in the lower third of the system (containing uranium) while minimizing phosphate mass that leached out of the bottom of the column (representing the water table).

Efficiency of phosphate solution infiltration and subsequent phosphate precipitate at depth was shown in a previous study to be time dependent (Szecsody et al. 2009). Therefore, it was hypothesized that rapid solution infiltration (i.e., as rapid as sediment will allow; a Darcy flux of $10 \mathrm{~cm} / \mathrm{h}$ or higher) followed by slow infiltration of water (with no phosphate) would maximize phosphate precipitation at depth. Although that previous study showed that phosphate retardation (i.e., from a combination of phosphate adsorption and precipitation) increased with slower infiltration (100-N sediment, Darcy flux 0.28 to $142 \mathrm{~cm} / \mathrm{h}$ ), experimental results in this study for 300 Area sediments showed that for a Darcy flux range of 3.0 to $29 \mathrm{~cm} / \mathrm{h}$ in these infiltration columns, there was no difference in the phosphate retardation, which averaged $3.84 \pm 1.34$ pore volumes (Table 4.5 ). To obtain $90 \%$ phosphate concentration at a 10 -ft depth, $7.1 \pm 4.6$ pore volumes of solution are needed, so smaller phosphate pulses advect only a lower phosphate 
concentration to depth. A large phosphate infiltration pulse (Figure 4.15a) with average breakthrough of $18.8 \mathrm{~h}$ relative to the bromide tracer of $4.56 \mathrm{~h}$ resulted in a phosphate retardation factor of 4.12 . The resulting phosphate vertical profile was the same for all applications (Figure 4.15d, black squares). Advection of water after a smaller pulse of phosphate did advect more phosphate mass to 8- to 10 - $\mathrm{ft}$ depth, as shown in Figure 4.15d (red diamonds), while minimizing phosphate loss at the bottom of the column (Appendix D for phosphate profiles of infiltration experiments). The 47-mM phosphate solution resulted in $0.9 \mathrm{mg} \mathrm{PO}_{4} / \mathrm{g}$ sediment. Because 2 to 10 pore volumes of the solution were injected, twice the mass of phosphate precipitate resulted, averaging $1.91 \pm 0.85 \mathrm{mg} / \mathrm{g}$ (range 0.67 to $3.77 \mathrm{mg} / \mathrm{g}$ ). The phosphate precipitated in sediments with slower infiltration rates showed a greater phosphate mass than higher infiltration rates. An infiltration strategy of multiple pulses of phosphate-laden solution followed by water infiltration to increase phosphate precipitate mass at depth in a zone of uranium-contaminated sediment being evaluated in seven 3-m (10-ft) columns (Table 3.4) was not completed due to funding. This strategy was effective at greatly increasing phosphate precipitate mass at depth at a smaller laboratory scale in a prior study (Szecsody et al. 2009).

In these infiltration experiments, some uranium was leached from the sediment as a direct result of uranium-carbonate desorption (ion exchange) from the high ionic strength phosphate solution. Peak effluent uranium concentrations averaged $417 \pm 131 \mu \mathrm{g} / \mathrm{L}$ at $0.72 \pm 0.18$ pore volumes for a short duration, with the breakthrough curve shape indicative of ion exchange. In comparison, groundwater infiltration showed a $323-\mu \mathrm{g} / \mathrm{L}$ uranium peak at 0.69 pore volumes (experiment A69, Table 4.5). This demonstrated that the increased uranium peak was caused by the ionic strength of the injecting solution. The mass of uranium leached by the phosphate solution averaged $0.0256 \pm 0.0152 \mu \mathrm{g} / \mathrm{g}$, which was $78 \%$ of the total uranium leached out of the sediment in $<10$ pore volumes. However, this leached uranium mass was small relative to the total labile uranium in the sediment $(0.078 \mu \mathrm{g} / \mathrm{g}$, so initial uranium peak was $33 \%$ of labile uranium) and small relative to the total extractable uranium in the sediment $(0.528 \mu \mathrm{g} / \mathrm{g}$ total extractable uranium so initial uranium peak was $4.8 \%$ of the total extractable uranium). In contrast, water-saturated experiments described earlier (Table 4.1 and 4.2) showed lower peak uranium effluent concentrations relative to groundwater injection and the total uranium mass leached from sediment as a result of phosphate injection averaged $15 \%$ of total labile uranium. Differences between concentration and mass of uranium leaching between infiltration and water-saturated injections experiments is likely the result of significantly longer sediment-phosphate contact time (19 to $4400 \mathrm{~h}$ ) in some experiments before uranium was leached from the sediment during groundwater flow. Infiltration experiments had uranium breakthrough more rapidly (hours to days), which did not allow as much time for phosphate to precipitate and sequester uranium. Uranium surface phases along the vertical profile were characterized in some infiltration experiments with sequential liquid extractions and showed a decrease in labile uranium (i.e., pH 5 acetate extraction, red circles, Figure 4.15e).

Overall, the infiltration approach resulted in a high phosphate precipitate loading in sediment (averaging $1.91 \pm 0.85 \mathrm{mg} \mathrm{PO}_{4} / \mathrm{g}$ ) as compared with water-saturated phosphate solution injection (averaging $0.18 \mathrm{mg} / \mathrm{g}$, Table 4.5 ) and the water-saturated phosphate-xanthan injection (averaging $0.28 \mathrm{mg} / \mathrm{g}$ ). The polyphosphate solution infiltration released initial concentrations of uranium that was higher (average $417 \mu \mathrm{g} / \mathrm{L}$, range 315 to $764 \mu \mathrm{g} / \mathrm{L}$ ) compared to untreated sediment with infiltration of water $(323 \mu \mathrm{g} / \mathrm{L})$. Uranium peak aqueous concentrations for these infiltration columns with phosphate treatment were higher than water-saturated experiments with the same phosphate solution (uranium concentration range, 10 to $80 \mu \mathrm{g} / \mathrm{L}$ ) and phosphate-xanthan solution injection in water-saturated systems (108 $\mu \mathrm{g} / \mathrm{L}$ uranium) likely due to little phosphate-sediment contact time, which would allow phosphates to precipitate and sequester some uranium. 
Table 4.5. Uranium Leaching and Phosphate Delivery in Unsaturated Columns

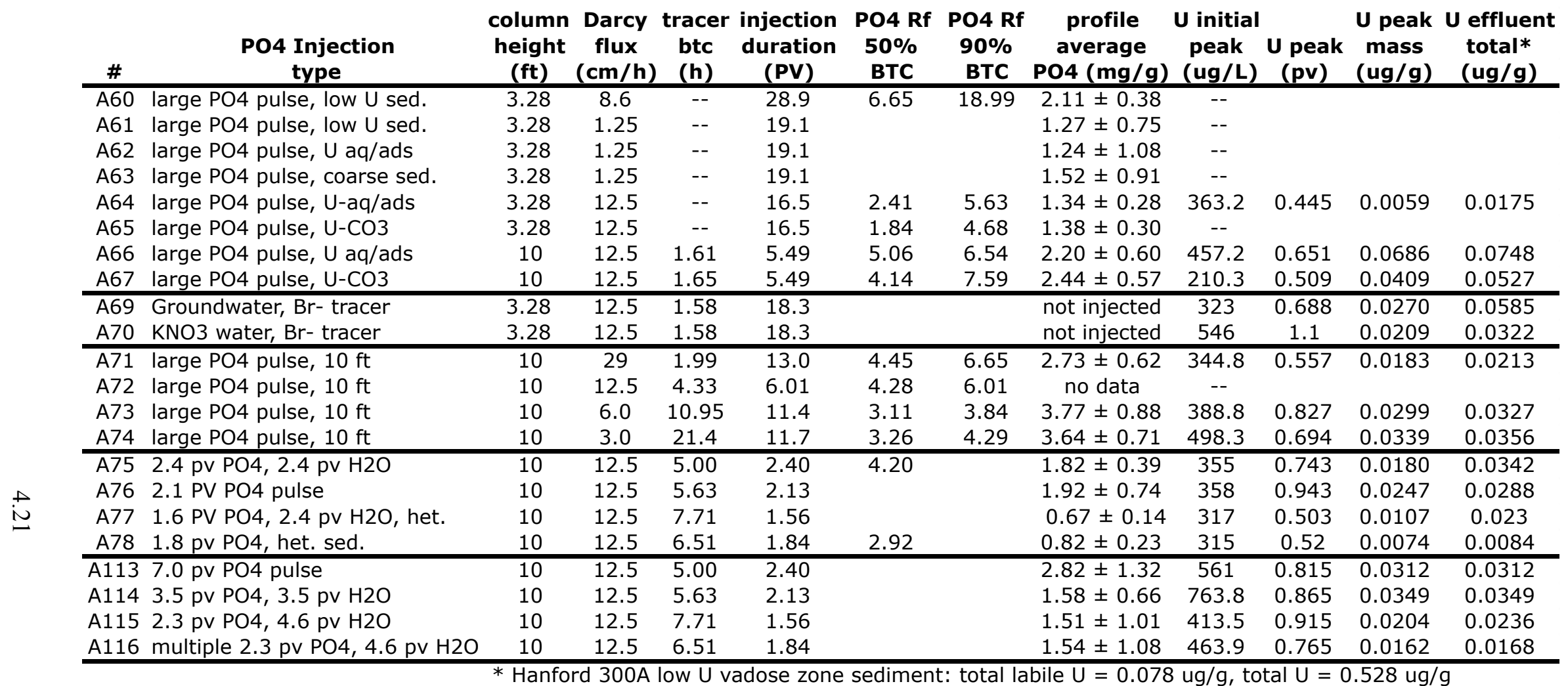




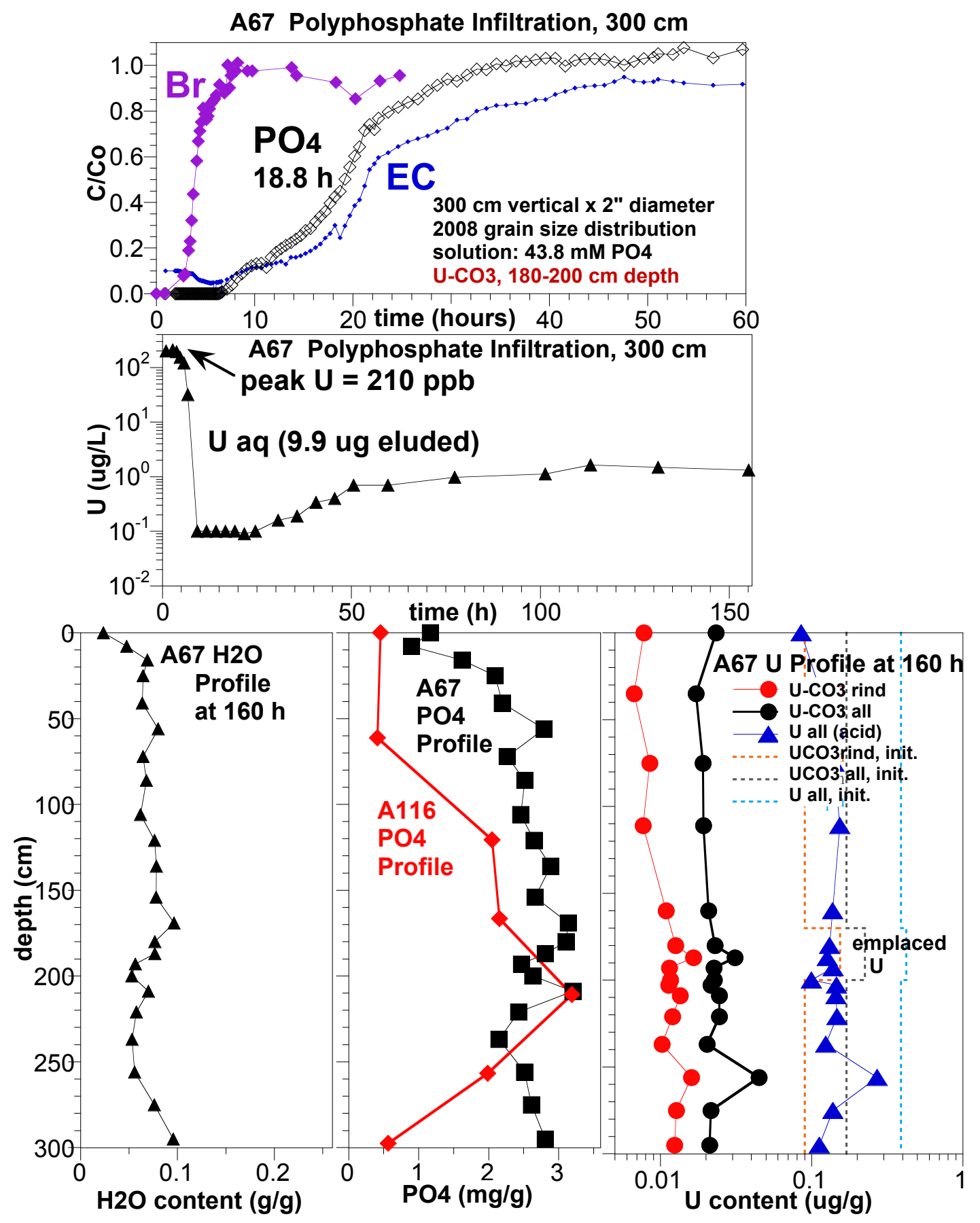

Figure 4.15. Infiltration of a Large Pulse Polyphosphate Solution into a 300-cm High Column: (a) $\mathrm{Br}$ and $\mathrm{PO}_{4}$ Breakthrough, (b) Uranium Breakthrough, (c) $\mathrm{H}_{2} \mathrm{O}$ Vertical Water Profile after Experiment, (d) $\mathrm{PO}_{4}$ Vertical Profile, and (e) Uranium Surface Phase Vertical Profile. Phosphate vertical profile also includes results of a second experiment (A116), which was a small $\mathrm{PO}_{4}$ pulse infiltration followed by water infiltration to precipitate $\mathrm{PO}_{4}$ at depth. 


\subsection{Conclusions and Challenges}

In this study, the short- and long-term effect of phosphate treatment on uranium mobility in uraniumcontaminated 300 Area sediments was investigated by comparison of aqueous uranium leaching and changes in surface-associated uranium between untreated and phosphate-treated sediments in columns that received hundreds of pore volumes of groundwater or river water flow over time periods ranging to a year.

In addition to uranium leaching, delivery of phosphate to sediments was also evaluated in these water-saturated columns as well as in large (10-ft high) phosphate infiltration columns. During continuous groundwater or river water flow, the untreated sediment (total uranium, $1.55 \mu \mathrm{g} / \mathrm{g}$ ) leached 5 to $12 \mu \mathrm{g} / \mathrm{L}$ uranium into solution and during stop flow events (200 to $1000 \mathrm{~h}$ ), aqueous uranium peaked to $150 \mu \mathrm{g} / \mathrm{L}$. In contrast, phosphate-treated sediments leached 1- to $10-\mu \mathrm{g} / \mathrm{L}$ uranium into solution during continuous water flow and 0 to $2 \mu \mathrm{g} / \mathrm{L}$ during stop flow events indicating uranium released from sediment was being removed from solution by the presence of the phosphate precipitate.

Although phosphate treatment did not completely eliminate uranium leaching from sediment, the long-term decrease in leaching rate, leached mass, and changes in nonlabile uranium were significant compared with untreated sediment. For a wide range of phosphate treatments in 13 column experiments, the average uranium mass advected out of the sediment was $0.385 \pm 0.283 \mu \mathrm{g} / \mathrm{g}$, compared with $0.833 \pm$ $0.298 \mu \mathrm{g} / \mathrm{g}$ for untreated sediments, or a $54 \%$ decrease in leached uranium mass over hundreds of pore volumes. The amount of uranium mass leached during phosphate treatment (i.e., first 50 pore volumes) was small, averaging $0.198 \pm 0.233 \mu \mathrm{g} / \mathrm{g}$ (13 experiments), or $15 \%$ of the total labile uranium in the sediment $(1.29 \mu \mathrm{g} / \mathrm{g})$. The average nonlabile uranium (i.e., $8 \mathrm{M} \mathrm{HNO}_{3}$-extractable) for untreated sediments of $0.255 \pm 0.080 \mu \mathrm{g} / \mathrm{g}$ increased to $0.516 \pm 0.259$ for phosphate-treated sediments. The cause of the decrease in labile uranium for phosphate-treated sediments is poorly understood, but may be the result of non-uranium phosphate precipitates coating uranium surface phases or the slow formation of uranium-phosphate precipitates.

A comparison of a high phosphate treatment to no treatment with river water injection over a time period of $4500 \mathrm{~h}$ shows the evolution of phosphate-treated sediment from initial high efficiency to decreased efficiency over time. Early in experiments $(<1000 \mathrm{~h})$, stop flow events (200 to $1000 \mathrm{~h})$ resulted $150 \mu \mathrm{g} / \mathrm{L}$ uranium aqueous concentrations for untreated sediments in contrast to $0.0 \mu \mathrm{g} / \mathrm{L}$ uranium for phosphate-treated sediments. As flow of clean river water resumed, the uranium concentration in phosphate-treated sediments increased to steady state $5-10 \mu \mathrm{g} / \mathrm{L}$ influent uranium concentration. These negative peaks after stop flow events indicate uranium that is released by sediment into pore water was being consumed (i.e., precipitated or coated by precipitates) at a greater rate than the sediment release rate. As experiment times approached $4500 \mathrm{~h}$, these negative uranium peaks for leaching from phosphate treated sediments were less pronounced and uranium-leaching rates approached that of untreated sediments.

During phosphate solution injection or infiltration into uranium-contaminated sediments, both uranium-carbonate species desorption and slow precipitation of phosphates controlled the aqueous uranium concentration evolution. Uranium-carbonate complexes in sediment desorb upon the injection of a high ionic strength solution (i.e., assuming no precipitation) showing a high concentration, short 
duration aqueous peak. However, increased contact time between the phosphate solution and sediment results in greater phosphate precipitate, which then sequesters uranium by coating or coprecipitation. Phosphate solution infiltration at short time scales (1 to $20 \mathrm{~h}$ ) in 3-m (10-ft) high columns did result in a moderate increase in uranium peak aqueous concentration of $415 \pm 131 \mu \mathrm{g} / \mathrm{L}$ (range 315 to 764 ) for a short duration $(<1$ pore volume, characteristic of ion exchange) compared with an untreated infiltration column (uranium peak was $323 \mu \mathrm{g} / \mathrm{L}$ ). In contrast, water-saturated column experiments in which phosphate was reacted with sediment for times ranging from 19 to $4400 \mathrm{~h}$ before advective flow, resulted in a significantly lower uranium peaks $(89.0 \pm 54.7 \mu \mathrm{g} / \mathrm{L}$, range 10 to 176$)$ compared with untreated sediments $(300 \pm 173 \mu \mathrm{g} / \mathrm{L}$, range 154 to 491$)$.

The injection strategy for polyphosphate treatment of sediments that resulted in the greatest decrease in uranium leaching was to a) maximize the no-flow phosphate-sediment reaction time before groundwater advection, b) use a high $(\sim 50 \mathrm{mM})$ phosphate concentration, and c) use xanthan with the polyphosphate solution. The increased reaction time from $19 \mathrm{~h}$ to $4400 \mathrm{~h}$ resulted in lower uranium leaching and increased immobile uranium fraction. This corresponded to little difference in the nonlabile uranium between phosphate-treated and untreated sediments for reaction times less than $100 \mathrm{~h}$, but a 2- to 3 -times increase for $1000 \mathrm{~h}$ or greater reaction time. This may be the result of recrystallization of phosphate precipitates over weeks to months, where evolved precipitates have lower solubility. Results in this study showed little difference in uranium leaching between low $(8 \mathrm{mM})$ or high $(47 \mathrm{mM})$ phosphate treatments of sediment, likely due to $1000 \times$ excess phosphate mass (relative to uranium mass) in this lowuranium sediment. A separate study in which low phosphate treatment was insufficient relative to the high uranium mass in that sediment (Shi et al. 2008) did show decreased longevity of the effect on uranium leaching. The significant increase in the nonlabile (immobile) uranium phase for phosphatexanthan treatments (average $0.889 \pm 0.206 \mu \mathrm{g} / \mathrm{g})$ compared to phosphate treatments $(0.447 \pm 0.211 \mu \mathrm{g} / \mathrm{g}$, untreated sediment $0.255 \pm 0.080$ ) may correspond to higher phosphate precipitate on mineral surfaces. Addition of xanthan to the polyphosphate solution greatly increased the viscosity $(100 \times)$ and shearthinning properties allowed injection, likely forcing solution into sediment microfractures.

In addition to those noted in previous publications (Wellman et al. 2007, 2008a, 2011; Bovaird et al. 2010; Vermeul et al. 2009), some limitations of polyphosphate treatment technologies were identified, which impact field scale applicability in different treatment zones. The trend of increased sedimentphosphate contact time resulting in higher phosphate precipitate (and a greater decrease in uranium leaching) implies that polyphosphate injection into groundwater may not deposit sufficient phosphate precipitate due to high groundwater flow (i.e., insufficient contact time). Water-saturated injections of the polyphosphate solution into the smear zone would also have sediment-phosphate solution reaction time limited by groundwater level and drainage of the solution. The use of xanthan, if high viscosity conditions was maintained for weeks or longer, would allow for a longer phosphate-sediment reaction time within the smear zone before groundwater is advected into the treatment zone. Unfortunately, the xanthan viscosity decreased rapidly (average half-life $52.1 \mathrm{~h}$ in packed porous media) and appeared to be abiotically controlled. The xanthan viscosity decrease was more rapid at a higher sediment/water ratio, indicative that either microbes or specific minerals associated with the sediment were degrading or reconfiguring the xanthan. While the addition of xanthan to the polyphosphate solution appears to have significant positive benefit for decreasing leaching of uranium from sediment, because the high viscosity of the fluid needs to be maintained for weeks or longer and current tests show high viscosity is maintained for a week, additional research is needed. 
The mass of phosphate precipitate needed to decrease uranium leaching is significant. For 47-mM polyphosphate treatment of this 300 Area smear zone sediment $\left(\mathrm{U}_{\text {total }} 1.55 \mu \mathrm{g} / \mathrm{g}\right.$, total labile uranium $1.29 \mu \mathrm{g} / \mathrm{g}$ ), the $\mathrm{PO}_{4} / \mathrm{U}_{\text {total }}$ ratio was 887 (i.e., low efficiency in terms of phosphate needed), and after thousands of hours (hundreds of pore volumes of groundwater or river water), phosphate treatment resulted in an average of only $46 \%$ leached uranium mass and a $2.0 \times$ increase in the total nonlabile uranium. The mass of phosphate deposited in sediments from water-saturated phosphate injections $\left(0.18 \mathrm{mg} \mathrm{PO}_{4} / \mathrm{g}\right)$ and phosphate-xanthan injections $\left(0.28 \mathrm{mg} \mathrm{PO}_{4} / \mathrm{g}\right)$ was small. Phosphate infiltration resulted in a much higher phosphate precipitate mass (averaging $1.91 \pm 0.85 \mathrm{mg} \mathrm{PO} / \mathrm{g}$ ). In addition, phosphate precipitates take weeks to months (and years) to recrystallize into lower solubility phases that result in the decreased uranium leaching. Although phosphate solution infiltration from the surface resulted in a high phosphate precipitate mass along the profile in 3-m (10-ft) high columns, significant phosphate will precipitate at shallower depth, lowering the efficiency. The depth of phosphate precipitation can be increased to some extent by rapid solution infiltration followed by infiltration of a non-phosphate solution. Further optimization of an infiltration strategy is needed to precipitate sufficient phosphate at 20-25 ft depth. In addition, phosphate solution infiltration is dependent on the ability to infiltrate a solution at field scale, and a preliminary tracer infiltration experiment had limited success due to low-K zones. Remediation of uranium in subsurface sediments in high carbonate oxic groundwater geochemical conditions is challenging due to the predominance of $\mathrm{U}(\mathrm{VI})$-carbonate aqueous species that limits uranium complex adsorption to sediment and other absorbent phases.

Results of this study with a constant mass of uranium in sediment and constant groundwater (or river water) flux show uranium leaching from sediment was significantly decreased using phosphate treatment by an average of $54 \%$, although there was a greater decrease for optimal phosphate treatment. Because the rate at which uranium is removed from solution by the presence of phosphate precipitates is slow, the phosphate treatment appears to be most effective in low flow zones (i.e., smear zone where groundwater flow occurs only seasonally). At field scale, with additional spatial variation in uranium concentration in the sediment, water flux rates, and varying carbonate concentration in the water, simulations are needed to evaluate the efficacy of phosphate treatment and estimate groundwater leaching concentrations over time. 



\subsection{References}

Bond D, J Davis, and JM Zachara. 2008. "Uranium(VI) Release from Contaminated Vadose Zone Sediments: Estimation of Potential Contributions from Dissolution and Desorption." In Adsorption of Metals to Geomedia II, MO Barnett and DB Kent (eds.), U.S. Geological Survey, Menlo Park, California, and Pacific Northwest National Laboratory, Richland, Washington.

Bovaird CC, KA Rod, DM Wellman, and SC Strandquist. 2010. Supplemental Laboratory Development of Polyphosphate Remediation Technology for In Situ Treatment of Uranium Contamination in the Vadose Zone and Periodically Re-wetted Zone. PNNL-SA-76114, Pacific Northwest National Laboratory, Richland, Washington.

Brina R and AG Miller. 1992. "Direct Detection of Trace Levels of Uranium by Laser-Induced Kinetic Phosphorimetry." Analytical Chemistry 64(13):1413-1418.

Catalano J, J McKinley, J Zachara, S Heald, S Smith, and G Brown. 2008. "Changes in Uranium Speciation Through a Depth Sequence of Contaminated Hanford Sediments." Environmental Science and Technology 40(8):2517-2524.

Chao TT and L Zhou. 1983. "Extraction Techniques for Selective Dissolution of Amorphous Iron Oxides from Soils and Sediments.” Soil Science Society of America Journal 47:225-232.

Kohler M. DP Curtis, DE Meece, and JA Davis. 2004. "Methods for Estimating Adsorbed Uranium (VI) and Distribution Coefficients of Contaminated Sediments." Environmental Science and Technology $38: 240-247$.

Liu C, J Zachara, N Qafoku, and Z Wang. 2008. “Scale-Dependent Desorption of Uranium from Contaminated Subsurface Sediments." Water Resources Research 44:2454-2461.

Seright R and B Henrici. 1990. "Xanthan Stability at Elevated Temperature.” SPE Reservoir Engineering 5(1):52-60.

Shi Z, C Liu, J Zachara, Z Wang, and B Deng. 2009. "Inhibition Effect of Secondary Phosphate Mineral Precipitation on Uranium Release from Contaminated Sediments." Environmental Science and Technology 43:8344-8349.

Simpson BC, RA Corbin, MJ Anderson, CT Kincaid, and JM Zachara. 2006. Identification and Classification of the Major Uranium Discharges and Unplanned Releases at the Hanford Site Using the Soil Inventory Model (SIM) Rev. 1 Results. NUV-06-21106-ES-001-DOC Rev. 1, Novotec, USA Inc., Cincinnati, Ohio.

Smith SC and J Szecsody. 2011. "Influence of Contact Time on the Extraction of 233-Uranyl Spike and Contaminant Uranium from Hanford Site Sediment.” Radiochimica Acta 99:693-704.

Sumner ME. 2000. "Soil Fertility and Plant Nutrition." Section D in Handbook of Soil Science, CRC Press, Boca Raton, Florida. 
Szecsody J, L Zhong, M Oostrum, V Vermeul, J Fruchter, and J Campbell. 2011. "Use of Shear Thinning Fluids to Deliver Phosphate Amendment for Decreasing Uranium Mobility in the Hanford 300 Area: Laboratory Study Progress." Letter report to CH2M HILL Plateau Remediation Company, March 2011.

Szecsody JE, MJ Truex, L Zhong, NP Qafoku, MD Williams, JP McKinley, CT Resch, JL Phillips, D Faurie, and J Bargar. 2010. Remediation of Uranium in the Hanford Vadose Zone Using Ammonia Gas: FY10 Laboratory-Scale Experiments. PNNL-20004, Pacific Northwest National Laboratory, Richland, Washington.

Szecsody J, M Rockhold, M Oostrom, R Moore, C Burns, M Williams, L Zhong, J Fruchter, J McKinley, V Vermeul, M Covert, T Wietsma, A Breshears, and B Garcia. 2009. Sequestration of Sr-90 Subsurface Contamination in the Hanford 100-N Area by Surface Infiltration of a Ca-Citrate-Phosphate Solution. PNNL-18303, Pacific Northwest National Laboratory, Richland, Washington.

Vermeul VR, BN Bjornstad, BG Fritz, JS Fruchter, RD Mackley, DR Newcomer, DP Mendoza, ML Rockhold, DM Wellman, and MD Williams. 2009. 300 Area Uranium Stabilization Through Polyphosphate Injection: Final Report. PNNL-18529, Pacific Northwest National Laboratory, Richland, Washington.

Wellman DM, JS Fruchter, VR Vermeul, E Richards, DP Jansik, and E Edge. 2011. "Evaluation of the Efficacy of Polyphosphate Remediation Technology: Direct and Indirect Remediation of Uranium Under Alkaline Conditions." Technology and Innovation 13:151-164.

Wellman DM, EM Pierce, DH Bacon, M Oostrom, KM Gunderson, SM Webb, CC Bovaird, EA Cordova, ET Clayton, KE Parker, RM Ermi, SR Baum, VR Vermeul, and JS Fruchter. 2008a. 300 Area Treatability Test: Laboratory Development of Polyphosphate Remediation Technology for in Situ Treatment of Uranium Contamination in the Vadose Zone and Capillary Fringe. PNNL-17818, Pacific Northwest National Laboratory, Richland, Washington.

Wellman DM, JN Glovack, K Parker, EL Richards, and EM Pierce. 2008b. "Sequestration and Retention of Uranium(VI) in the Presence of Hydroxylapatite under Dynamic Geochemical Conditions." Environmental Chemistry 5(1):40-50.

Wellman DM, EM Pierce, EL Richards, BC Butler, KE Parker, JN Glovack, SD Burton, SR Baum, ET Clayton, and EA Rodriguez. 2007. Interim Report: Uranium Stabilization Through Polyphosphate Injection - 300 Area Uranium Plume Treatability Demonstration Project. PNNL-16683, Pacific Northwest National Laboratory, Richland, Washington.

Wellman DM, JP Icenhower, AP Gamerdinger, and SW Forrester. 2006a. "Effects of pH, Temperature, and Aqueous Organic Material on the Dissolution Kinetics of Meta-Autunite Minerals (Na, $\mathrm{Ca})_{2-1}\left[\left(\mathrm{UO}_{2}\right)\left(\mathrm{PO}_{4}\right)\right]_{2} \bullet 3 \mathrm{H}_{2} \mathrm{O}$." American Mineralogist 91:143-158.

Wellman DM, JP Icenhower, and AT Owen. 2006b. "Comparative Analysis of Soluble Phosphate Amendments for the Remediation of Heavy Metal Contaminants: Effect on Sediment Hydraulic Conductivity." Environmental Chemistry 3:219-224. 
Zachara J, C Liu, C Brown, S Kelly, J Christensen, J McKinley, J Davis, J Serne, E Dresel, and W Um. 2007. A Site-Wide Perspective on Uranium Geochemistry at the Hanford Site. PNNL-17031, Pacific Northwest National Laboratory, Richland, Washington. 



\section{Appendix A}

\section{Influence of Water Quality on Uranium Leaching}

from Untreated Sediments 



\section{Appendix A}

\section{Influence of Water Quality on Uranium Leaching from Untreated Sediments}

The 300 Area groundwater and smear zone contains physically and chemically heterogeneous zones with different uranium mass. As groundwater or river water (or mixtures of both) can advect through the sediment, uranium leaching can differ due to increased carbonate dissolution (in waters that are less than carbonate saturated) or highly mobile uranium adsorption can be influenced by the overall ionic strength of the water. Uranium leaching from river and groundwater of differing composition provide endpoints of expected leaching behavior. Therefore untreated and phosphate-treated experiments were conducted using water of differing chemical composition. Three baseline stop-flow experiments were conducted that include: a) Hanford 300 Area groundwater (both $13 \mu \mathrm{g} \mathrm{U} / \mathrm{L}$ and $0.08 \mu \mathrm{g} \mathrm{U} / \mathrm{L}$ ), b) Columbia River water ( $5 \mu \mathrm{g} \mathrm{U} / \mathrm{L})$, and c) uranium-free synthetic groundwater developed and used by the Integrated Field Research Center (IFRC) project.

The synthetic groundwater

(SGW-1) was based on the average composition of three well samples near the IFRC site, so is representative of the local groundwater composition, which has nitrate (and uranium) contamination. However, compared to groundwater composition over the broader Hanford 300 Area, SGW-1 has an ionic strength $83 \%$ higher. Carbonate and silica are lower; $\mathrm{Mg}^{2+}, \mathrm{Ca}^{2+}, \mathrm{Na}^{+}, \mathrm{K}^{+}, \mathrm{Cl}^{-}, \mathrm{SO}_{4}^{2-}$, and $\mathrm{NO}_{3}{ }^{-}$are higher (Table A.1).

Uranium adsorption was not compared specifically with these water compositions, but other studies have shown that increasing ionic strength decreases uranium adsorption (see Figure A.1), especially at low uranium concentrations and large differences in ionic strength. At $1 \mu \mathrm{g} / \mathrm{L}$, a large ionic strength increase (i.e., groundwater has an ionic strength of $0.011 \mathrm{~mol} / \mathrm{L}$, so increase $10 \times$ to $0.1 \mathrm{mmol} / \mathrm{L}$ ), uranium adsorption decreases from 1.5 to $0.7 \mathrm{~mL} / \mathrm{g}$. Given the $2 \times$ increase in ionic strength between real groundwater and SGW-1, uranium adsorption is estimated to decrease $40 \%$.

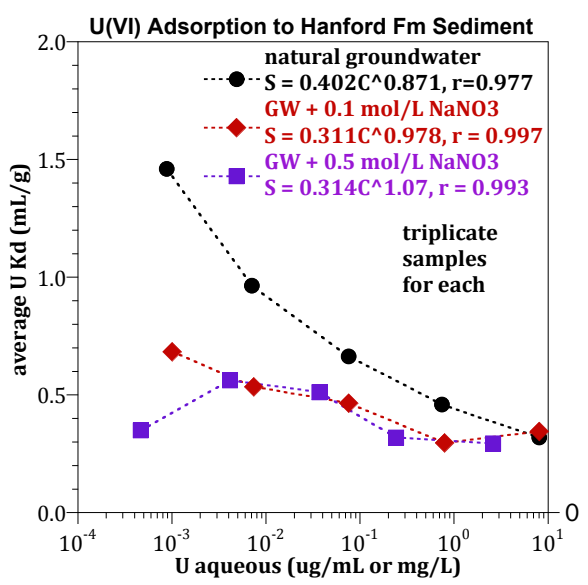

Figure A.1. Uranium Adsorption at Different Uranium Concentration and Water Composition 
Long-term leaching experiments were conducted (to $4500 \mathrm{~h}$ ), with multiple stop flows of $200 \mathrm{~h}$ to $1000 \mathrm{~h}$ each). Breakthrough curves (Figure A.2), and a summary of stop flow concentrations and uranium release rates (Tables A.2 and A.3) characterize differences in uranium leaching. The initial uranium peak during water saturation is high (150 to $500 \mu \mathrm{g} / \mathrm{L}$, Figure A.2) with significant mass (Table A.3). Stop flow events for both real groundwater and river water subsequently result in peak concentrations decreasing from $45 \mu \mathrm{g} / \mathrm{L}$ to $13 \mu \mathrm{g} / \mathrm{L}$. In contrast, uranium peak concentrations during stop flow events for the synthetic groundwater are approximately five times greater, with concentrations decreasing from $154 \mu \mathrm{g} / \mathrm{L}$ to $46 \mu \mathrm{g} / \mathrm{L}$. As a consequence, about twice as much mass was leached from the synthetic groundwater within 189 pore volumes, as compared to 200 pore volumes of real groundwater or 450 pore volumes or river water. However, calculated uranium release rates (Table A.3) are equal or lower for the synthetic groundwater than real groundwater or river water (as described below).

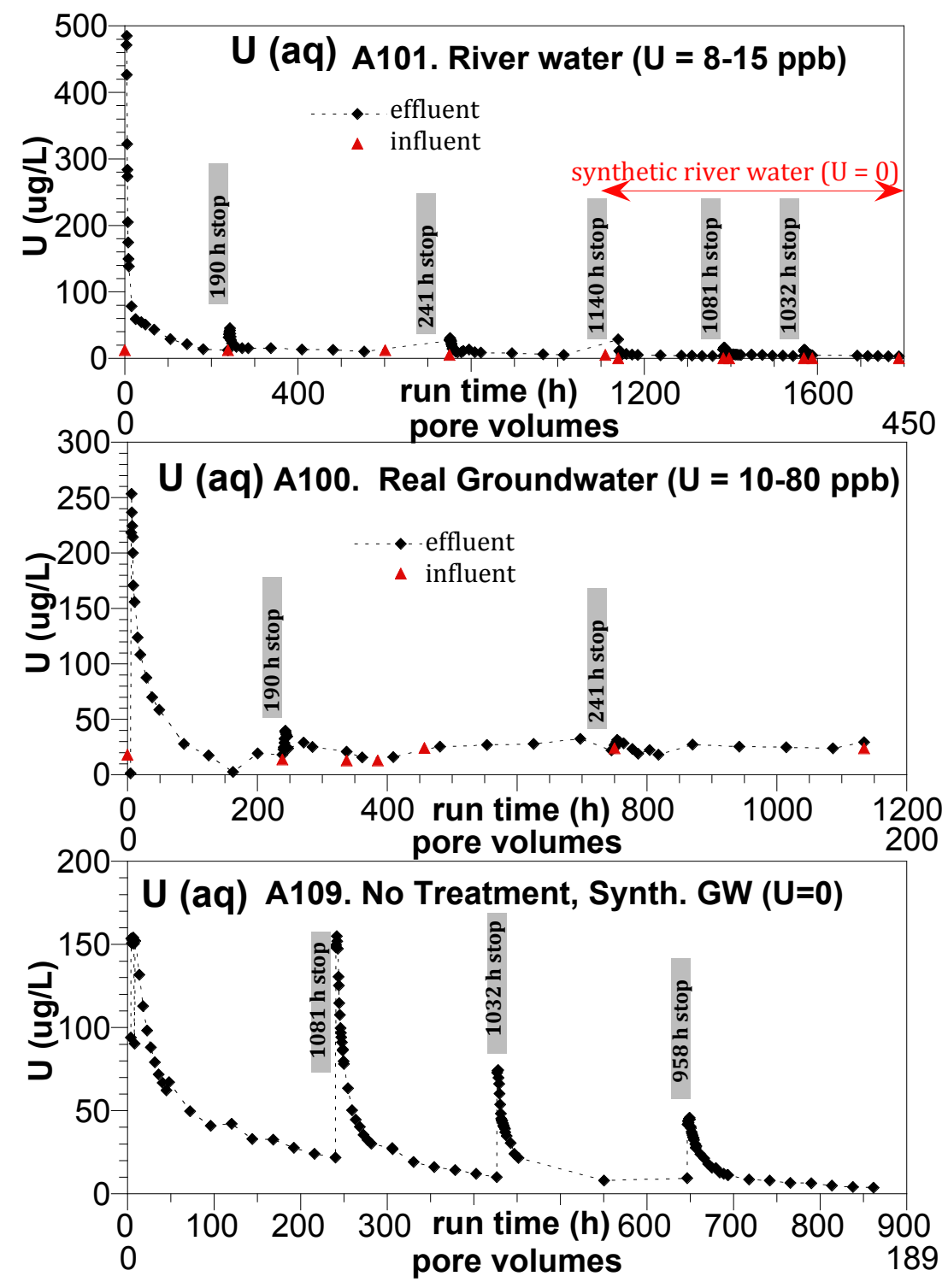

Figure A.2. Uranium Leaching from Untreated 300 Area Sediments Using (a) River Water, (b) Groundwater, and (c) Synthetic Groundwater 
Table A.2. Uranium Mass Balance for Untreated Sediment Leaching

\begin{tabular}{|c|c|c|c|c|c|c|}
\hline $\begin{array}{c}\text { exp. } \\
\text { \# }\end{array}$ & treatment & $\begin{array}{c}\text { total } \\
\text { labile U* } \\
\text { (ug/g) }\end{array}$ & $\begin{array}{c}\text { advected } \\
\text { U** } \\
(\mathbf{u g} / \mathrm{g})\end{array}$ & $\begin{array}{c}\text { nonlabile } \\
\mathbf{U} \\
(\mathrm{ug} / \mathrm{g})\end{array}$ & $\begin{array}{c}\text { aq+ads U } \\
(u g / g)\end{array}$ & $\begin{array}{l}\text { peak U } \\
(\mathrm{ug} / \mathrm{L})\end{array}$ \\
\hline-- & untreated & 1.290 & -- & 0.264 & 0.170 & -- \\
\hline A100 & untreated, 200 pv GW & 1.278 & 0.709 & 0.170 & 0.030 & 256 \\
\hline A101 & untreated 450 pv RW & 0.978 & 0.619 & 0.330 & 0.016 & 491 \\
\hline A109 & untreated, 190 pv SGW & - & 1.213 & -- & - & 154 \\
\hline
\end{tabular}

Table A.3. Uranium Release Rates for Untreated Sediment Leaching

\begin{tabular}{|c|c|c|c|c|c|c|c|}
\hline $\begin{array}{c}\text { exp. } \\
\text { \# }\end{array}$ & $\begin{array}{c}\text { exp } \\
\text { type }\end{array}$ & $\begin{array}{l}\exp \\
\text { (h) }\end{array}$ & $\begin{array}{c}\text { stop } \\
\text { flow } \\
\text { (h) }\end{array}$ & $\begin{array}{c}\text { U peak } \\
\text { conc after } \\
\text { stop }(u g / L)\end{array}$ & $\begin{array}{l}\text { release } \\
\text { rate } \\
(\mathrm{ug} / \mathrm{g} / \mathrm{h})\end{array}$ & $\begin{array}{c}\text { U mass } \\
\text { each stop } \\
(\mathrm{ug} / \mathrm{g})\end{array}$ & $\begin{array}{c}\text { U mass } \\
\text { total effluent } \\
(\mathrm{ug} / \mathrm{g})\end{array}$ \\
\hline \multirow[t]{3}{*}{ A100 } & untreated, gw & 0 & 0 & 253 & & 0.292 & \\
\hline & (high U gw) & 240 & 190.1 & 39.8 & $3.72 \mathrm{E}-05$ & 0.235 & \\
\hline & & 745 & 241.4 & 31.4 & $1.91 \mathrm{E}-05$ & 0.181 & 0.709 \\
\hline \multirow[t]{6}{*}{ A101 } & untreated, rw & 0 & 0 & 485 & & 0.306 & \\
\hline & & 239 & 190.1 & 45.5 & 4.11E-05 & 0.101 & \\
\hline & & 935 & 241.4 & 30.6 & $1.98 \mathrm{E}-05$ & 0.066 & \\
\hline & & 1566 & 1140 & 28.5 & $4.79 E-06$ & 0.041 & \\
\hline & & 2754 & 1081 & 16.2 & $2.79 \mathrm{E}-06$ & 0.071 & \\
\hline & & 4221 & 1032 & 13.0 & 2.17E-06 & 0.034 & 0.619 \\
\hline \multirow[t]{4}{*}{ A109 } & untreated, sgw & 0 & 0 & 154 & & 0.674 & \\
\hline & $(U=0$ in $s g w)$ & 240 & 1081 & 155 & $3.16 \mathrm{E}-05$ & 0.341 & \\
\hline & & 1507 & 1032 & 74.5 & $1.60 \mathrm{E}-05$ & 0.077 & \\
\hline & & 2759 & 957.5 & 45.7 & $9.74 \mathrm{E}-06$ & 0.121 & 1.213 \\
\hline
\end{tabular}

Uranium leaching from sediments is a result of multiple processes including desorption and dissolution of one or more uranium-containing surface phases. As uranium-carbonates are a substantial fraction of uranium surface phases, the carbonate concentration in the leaching water is a key factor in dissolution of surface carbonates (i.e., if leaching water is less that carbonate-saturated). SGW-1 is also low in silica relative to groundwater.

Of the total labile uranium in the untreated sediment (1.29 $\mu \mathrm{g} \mathrm{U} / \mathrm{g}$, first line, Table A.2), the total uranium advected during 200 pore volumes of natural Hanford groundwater injection (A100) was $0.71 \mu \mathrm{g} / \mathrm{g}$ versus during 450 pore volumes of river water was $0.62 \mu \mathrm{g} / \mathrm{g}$ (A101, Tables A.2 and A.3). In contrast, nearly twice as much uranium leached from sediment during 190 pore volumes of synthetic groundwater injection $(1.17 \mu \mathrm{g} / \mathrm{g}, \mathrm{A} 109)$. Carbonate in the river water is half-saturated, so roughly equal to SGW-1 (but lower overall ionic strength, about half that of real groundwater). It is hypothesized that the use higher uranium mass leaching from sediment in synthetic groundwater is caused by either the elevated ionic strength or low carbonate saturation of this water relative to natural groundwater.

Although breakthrough comparison at stop flow events show much higher uranium peaks for synthetic groundwater (Figure A.2 and Figure A.3b), the actual uranium release rate at stop flow events is the same or lower for synthetic groundwater compared to groundwater or river water (Figure A.3c). This apparent difference in breakthrough curves is due to the first few stop flow events for groundwater and 
river water being $\sim 200 \mathrm{~h}$ in duration, and subsequent stop flow events of $\sim 1000 \mathrm{~h}$, whereas the three stop flow events for synthetic groundwater are $\sim 1000 \mathrm{~h}$ in duration.
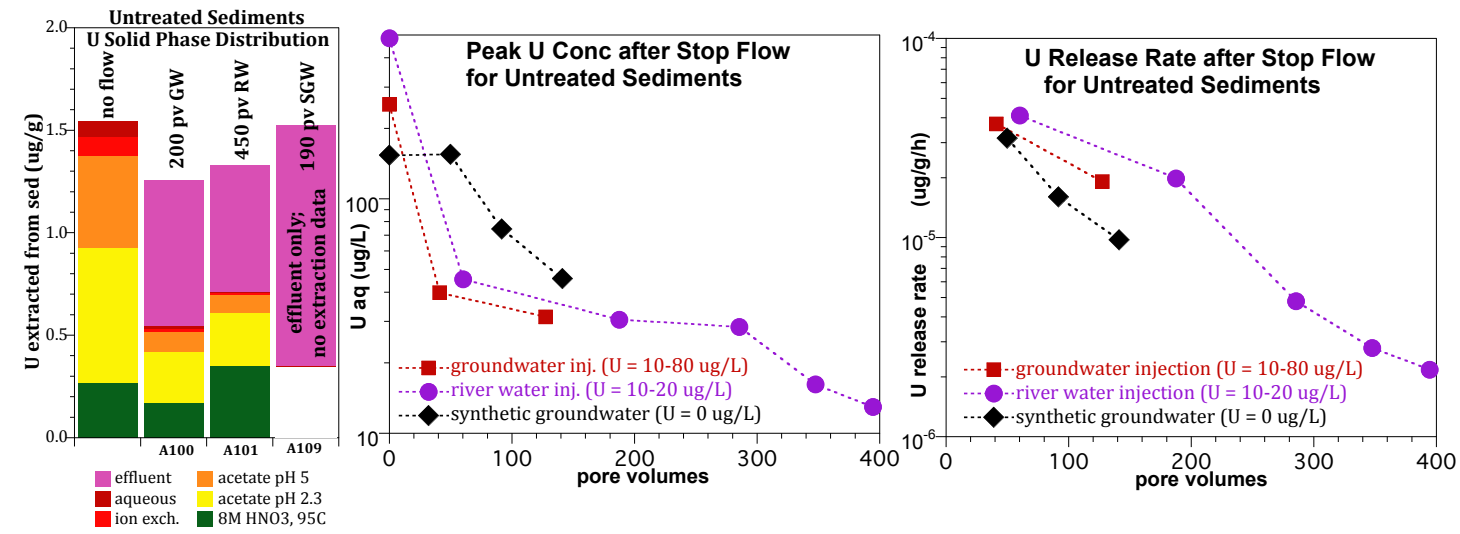

Figure A.3. Uranium Leaching from Untreated 300 area sediments as defined by (a) sequential extractions, (b) peak concentrations at stop flow events, and (c) calculated release rates at stop flow events.

If uranium release from sediments during these stop flow events was a result of diffusion from intraparticle pore space (and not dissolution of uranium from surface carbonates or other phases), the ions in the water would have little effect, assuming no difference in uranium adsorption, and the uraniumcarbonate solubility limit is not reached. Although synthetic groundwater resulted in $65 \%$ greater uranium leaching from 300 Area uranium-contaminated sediments compared with real groundwater or river water, it is likely that this difference is caused by decreased uranium adsorption (estimated at $40 \%$ lower for SGW-1 compared to real groundwater, Figure A.1). 


\section{Appendix B}

\section{Water-Saturated Stop Flow Column Experiments}





\section{Appendix B}

\section{Water-Saturated Stop Flow Column Experiments}
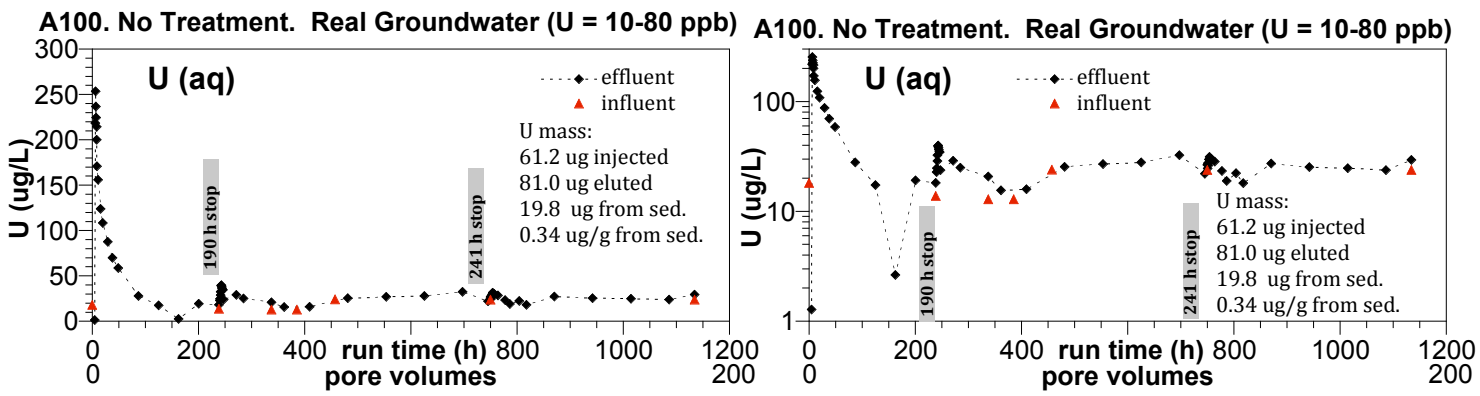

A101. No Treatment. Real river water $(U=8-15 \mathrm{ppb})$

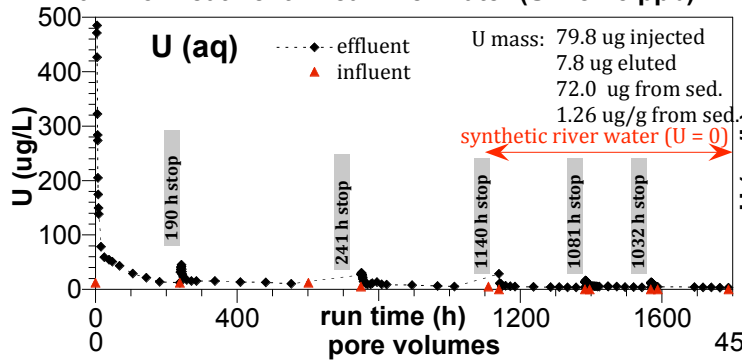

A101. No Treatment. Real river water $(U=8-15 \mathrm{ppb})$

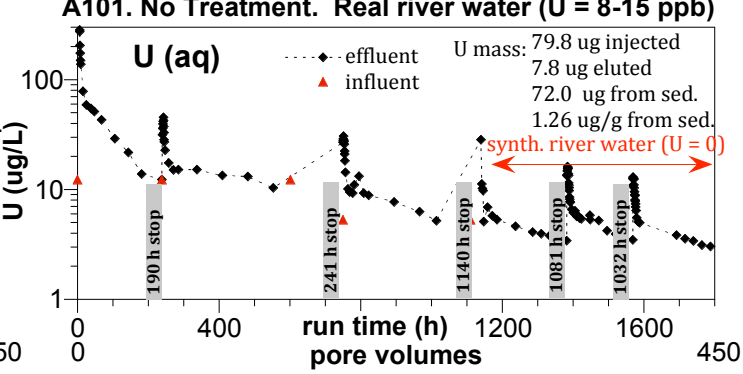

A102. $47 \mathrm{mM}$ PO4. Real Groundwater (U = 10-80 ppb)

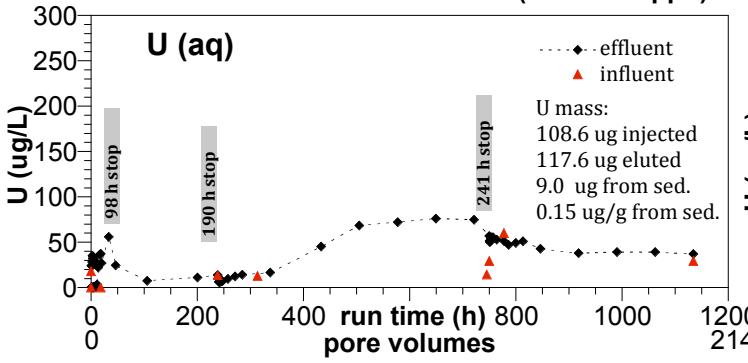

A102. $47 \mathrm{mM}$ PO4. Real Groundwater $(U=10-80 \mathrm{ppb})$
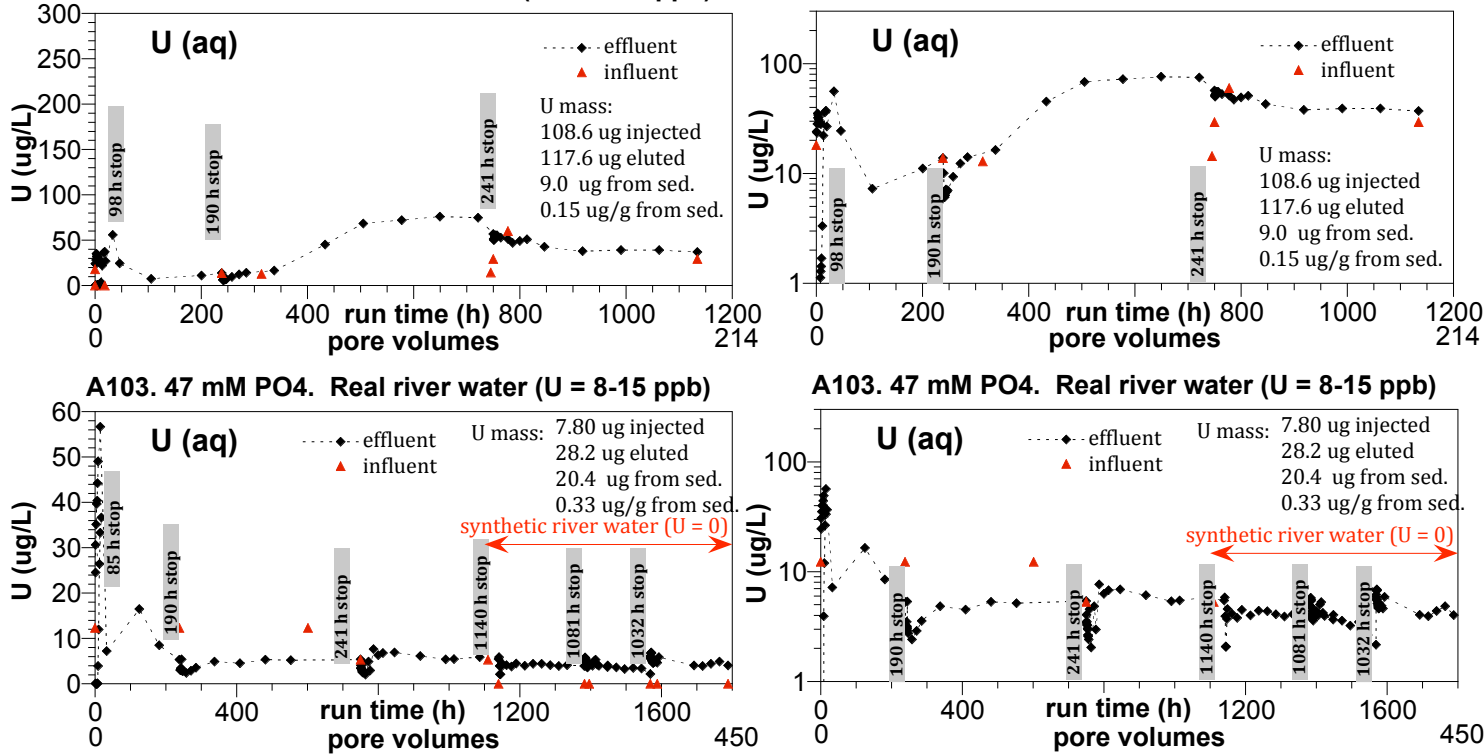

A103. $47 \mathrm{mM}$ PO4. Real river water $(U=8-15 \mathrm{ppb})$

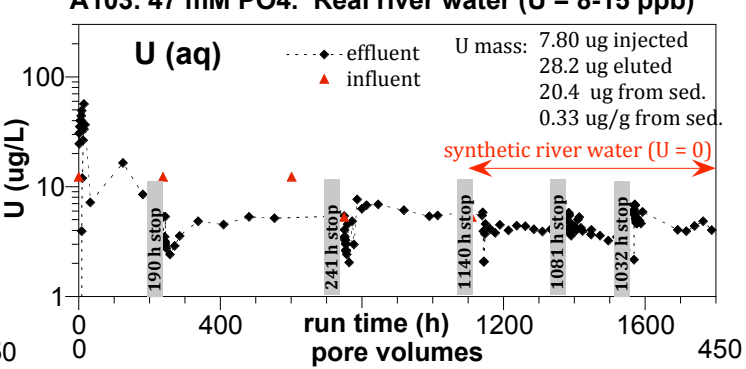

A104. $8 \mathrm{mM}$ PO4. Real Groundwater (U = 10-80 ppb)

A104. $8 \mathrm{mM}$ PO4. Real Groundwater $(U=10-80 \mathrm{ppb})$
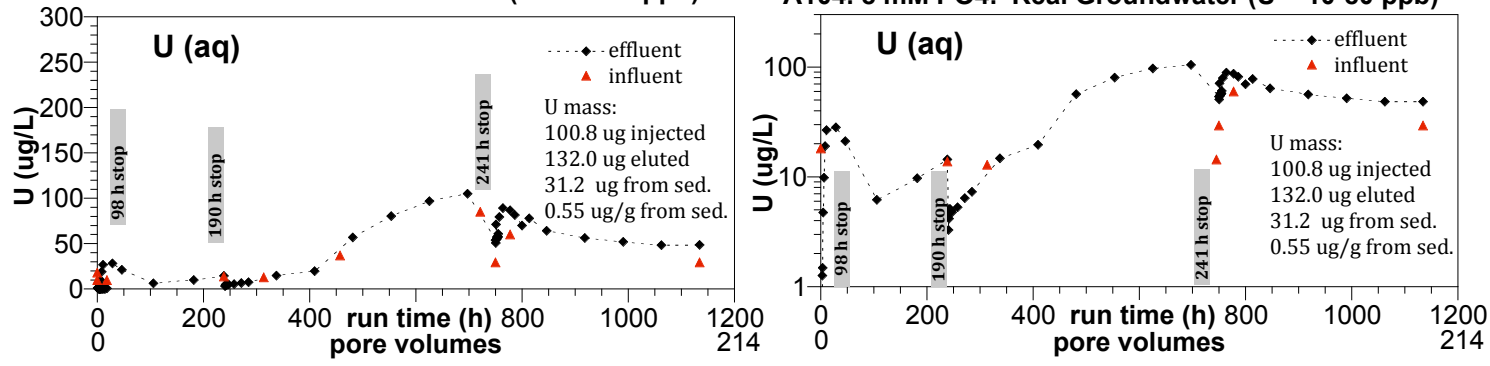

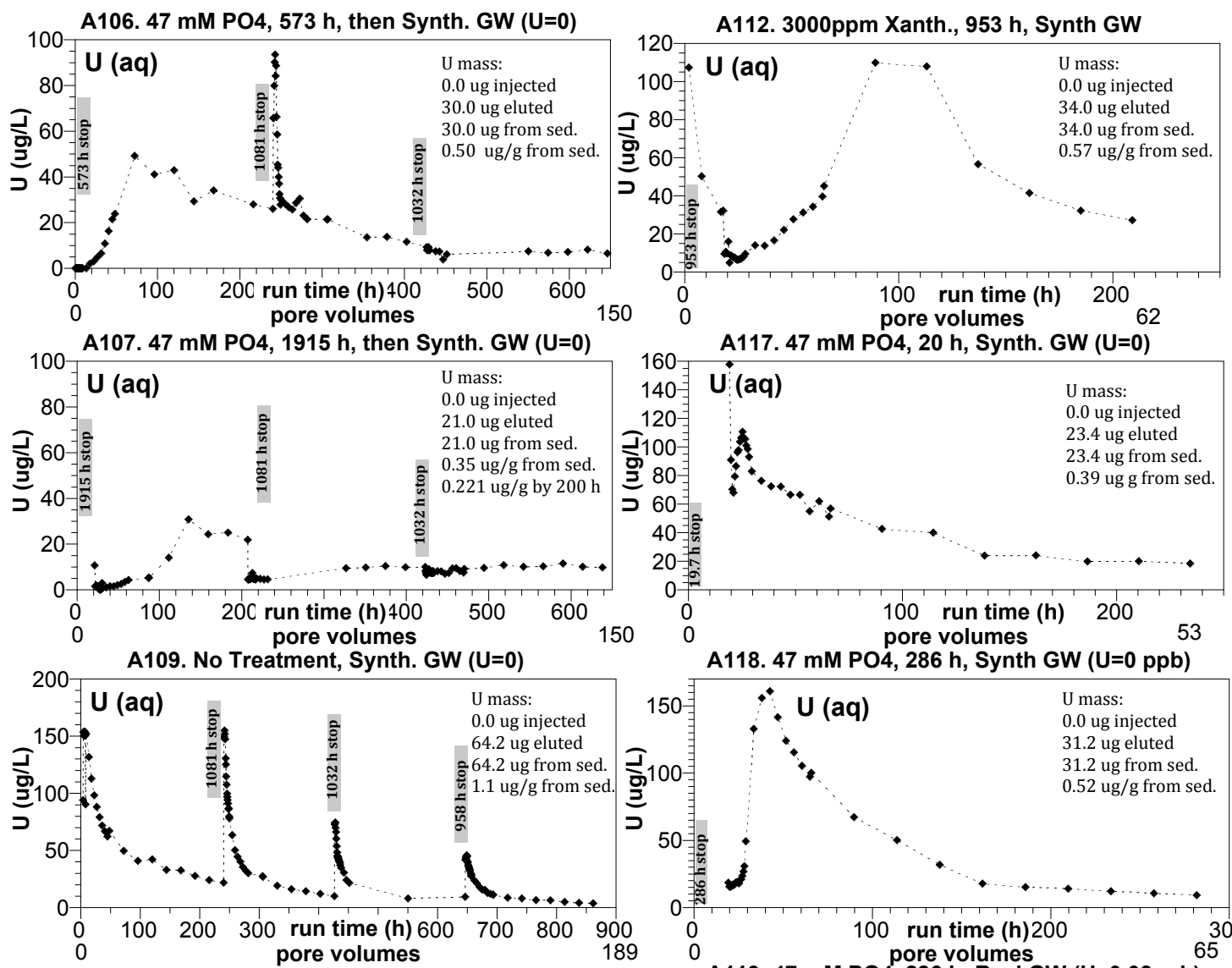

A118. 47 mM PO4, 286 h, Synth GW (U=0 ppb)

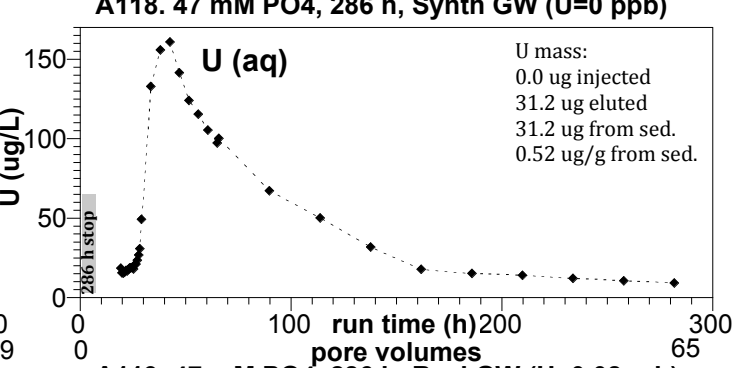

A110. 47mM PO4+3000ppm Xanth., 1100 h, Synth GW
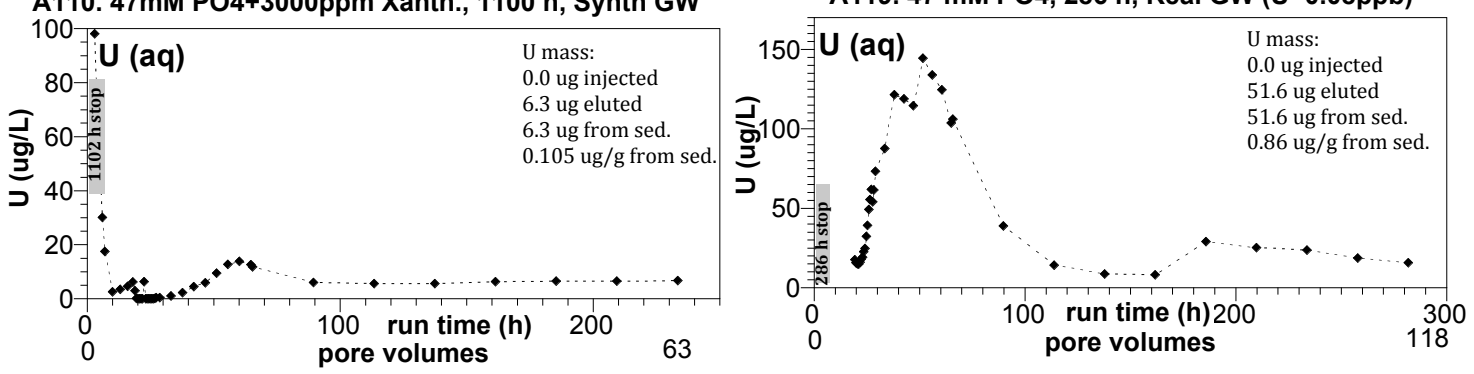

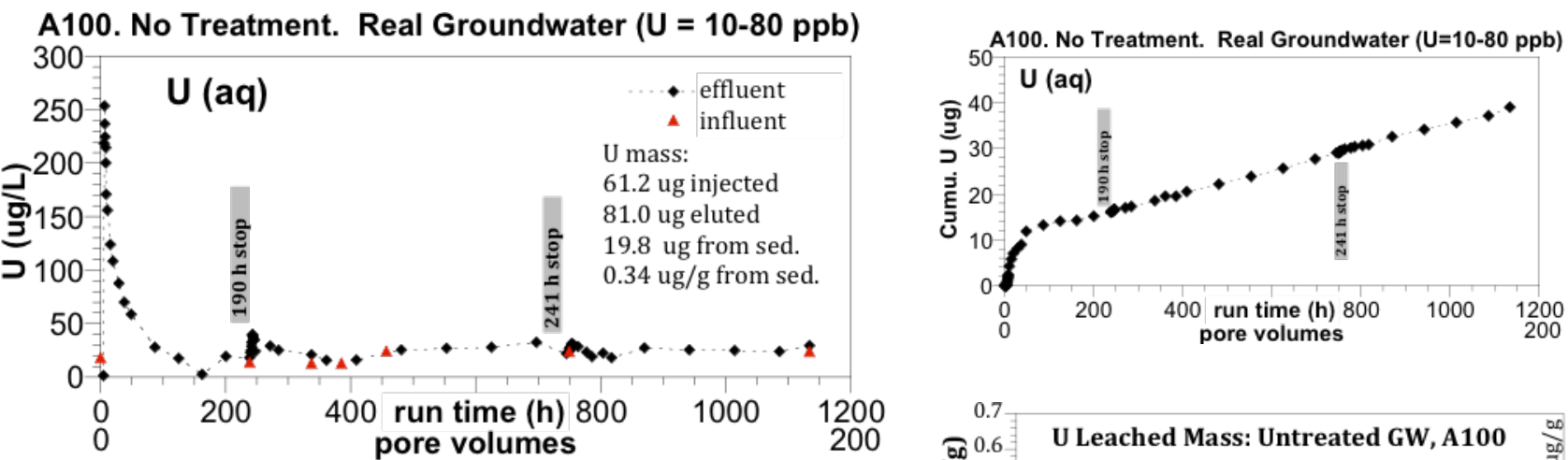

A100. No Treatment. Real Groundwater $(U=10-80 \mathrm{ppb})$
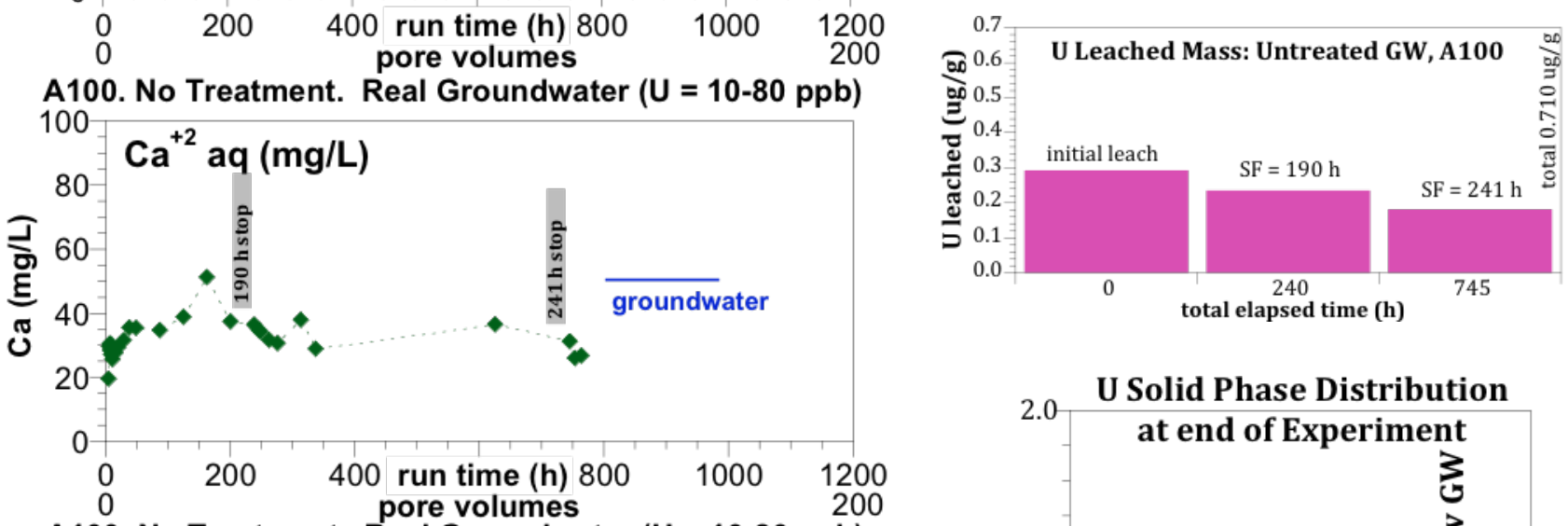

A100. No Treatment. Real Groundwater $(U=10-80 \mathrm{ppb})$

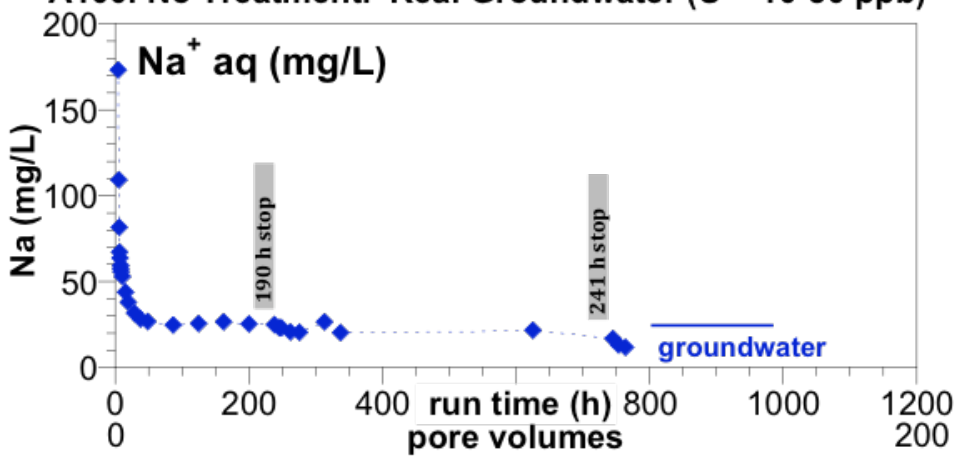

A100. No Treatment. Real Groundwater $(U=10-80 \mathrm{ppb})$
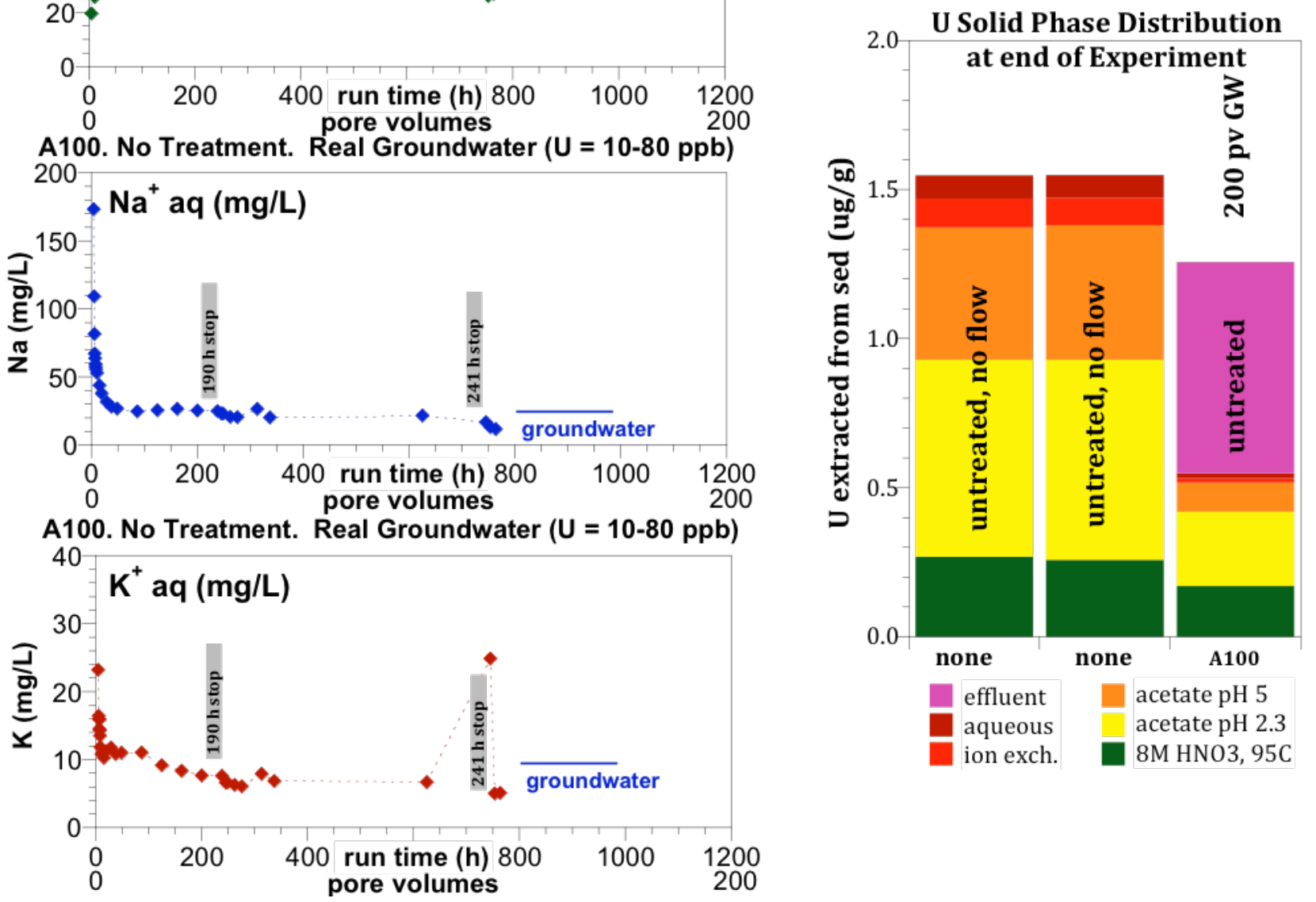
A101. No Treatment. Real river water $(U=8-15$ ppb)

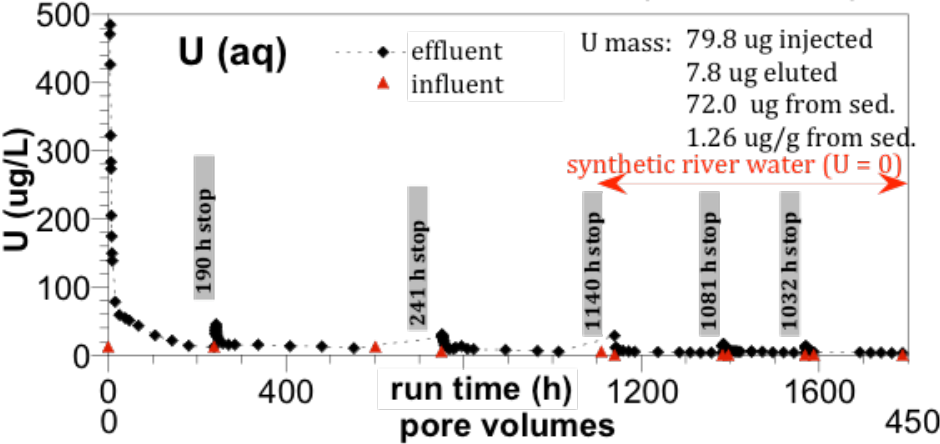

A101. No Treatment. Real river water $(U=8-15 \mathrm{ppb})$

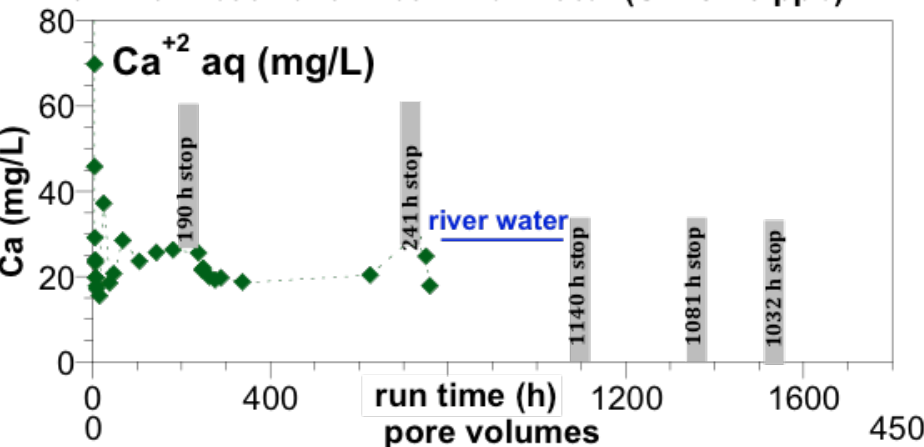

A101. No Treatment. Real river water $(U=8-15 \mathrm{ppb})$

$$
{ }_{80}^{100} \mathrm{Na}^{+} \mathrm{aq}(\mathrm{mg} / \mathrm{L})
$$
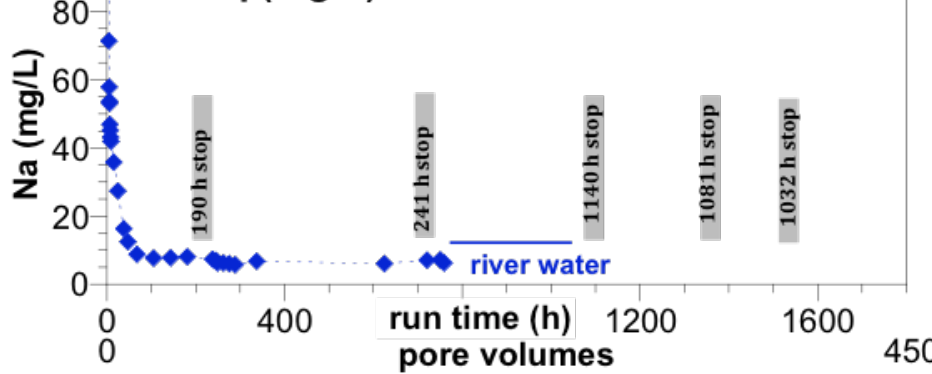

A101. No Treatment. Real river water $(U=8-15 \mathrm{ppb})$

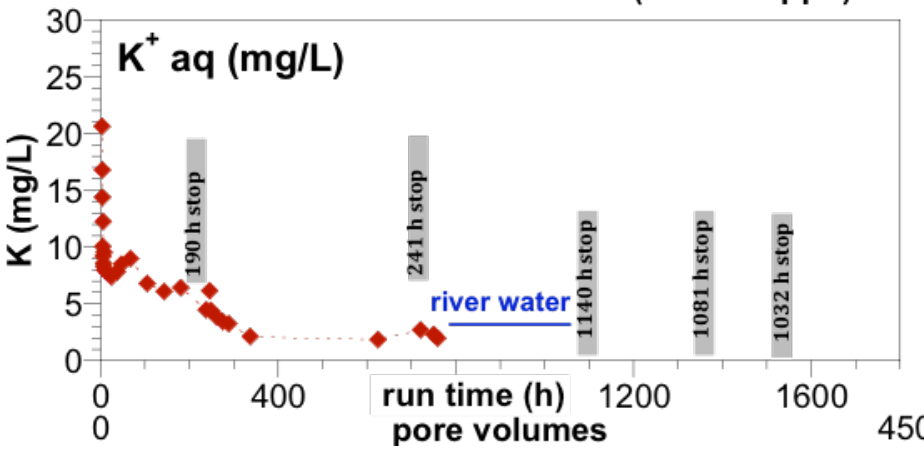

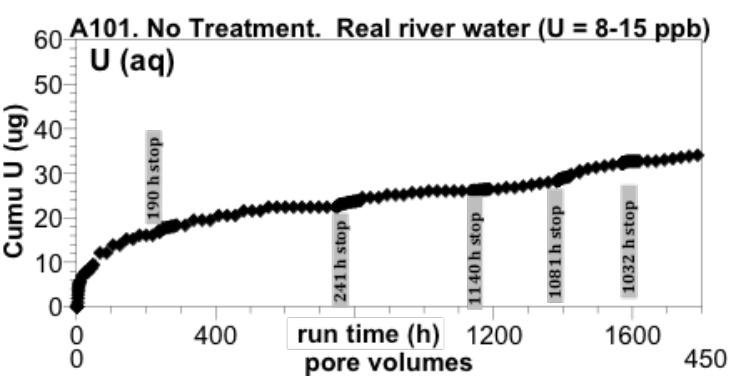
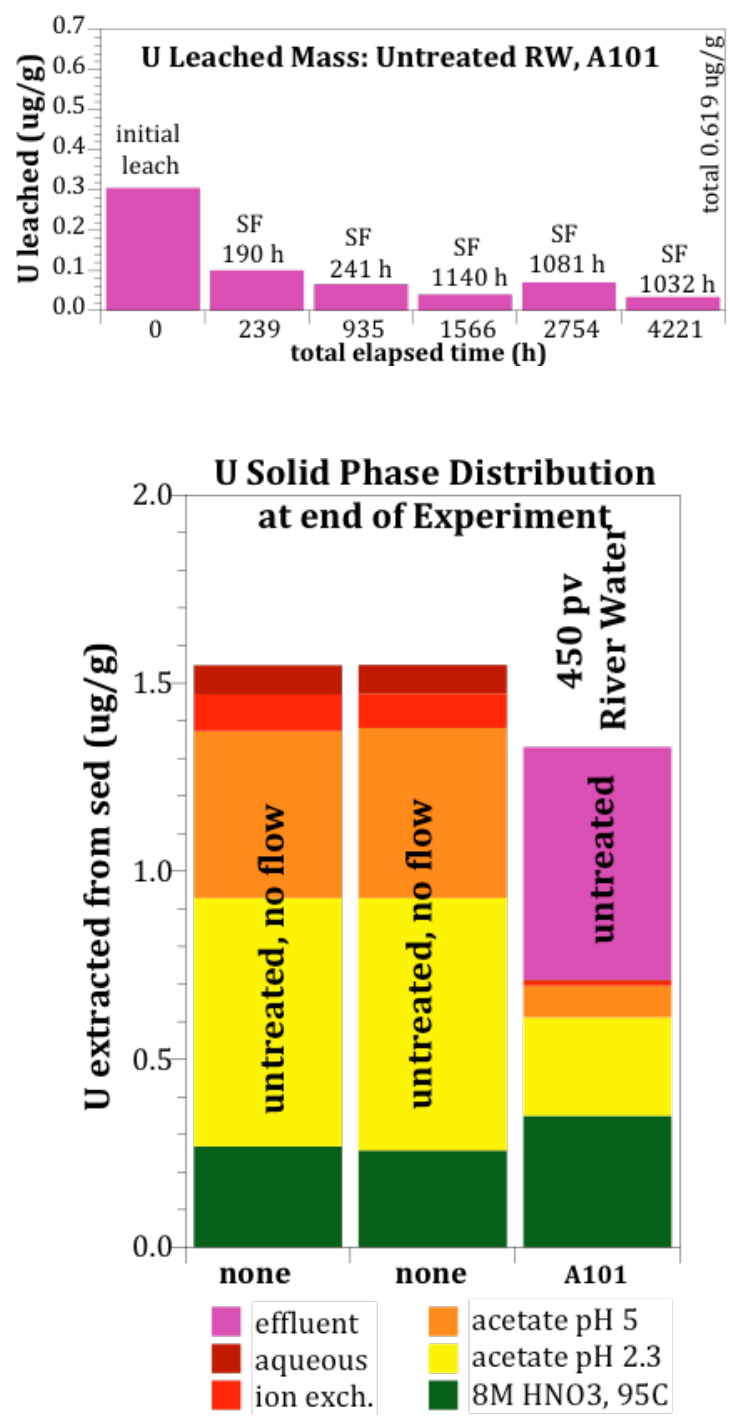
A102. $47 \mathrm{mM}$ PO4. Real Groundwater $(U=10-80 \mathrm{ppb})$
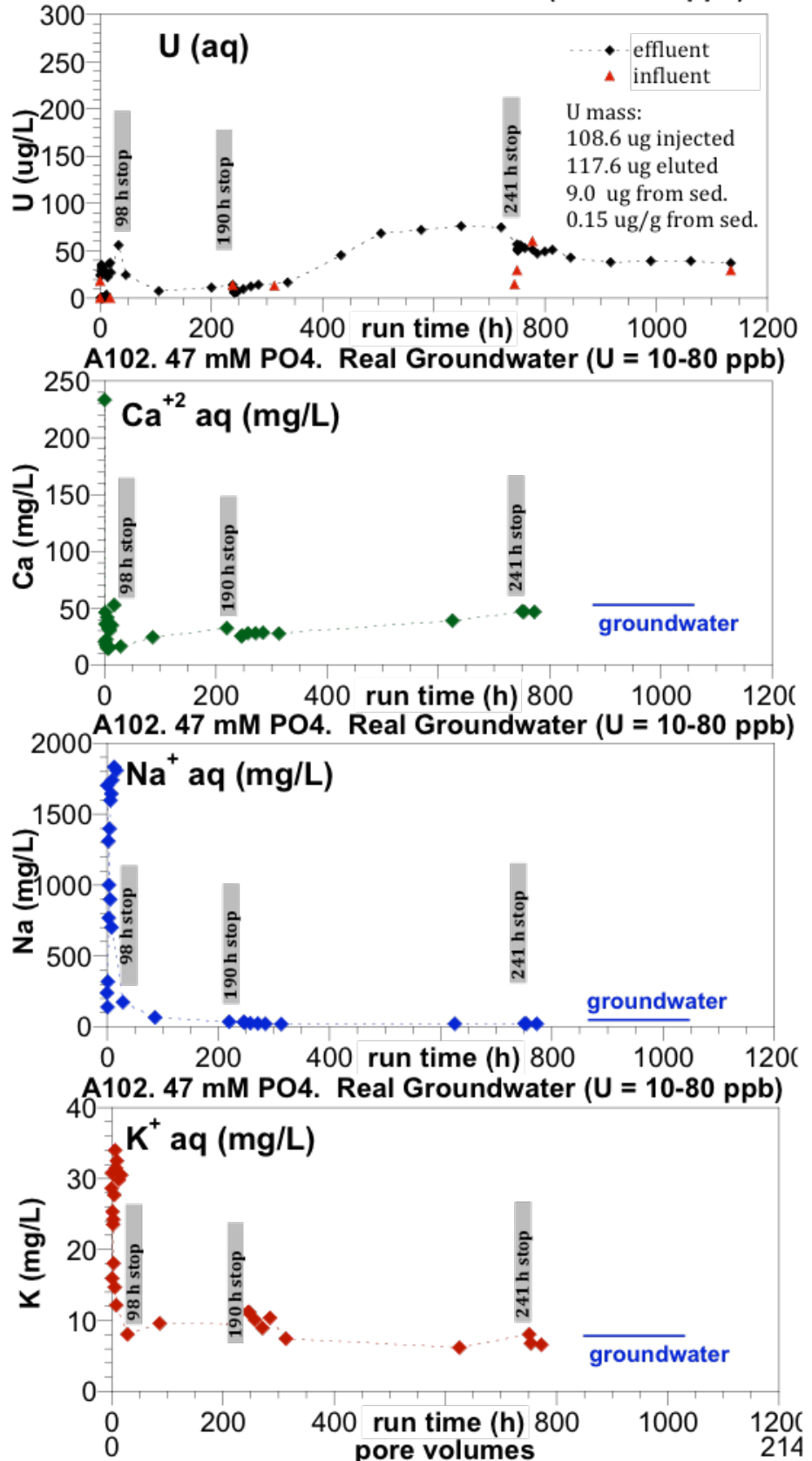

A102. $47 \mathrm{mM}$ PO4. Real Groundwater $(U=10-80 \mathrm{ppb})$

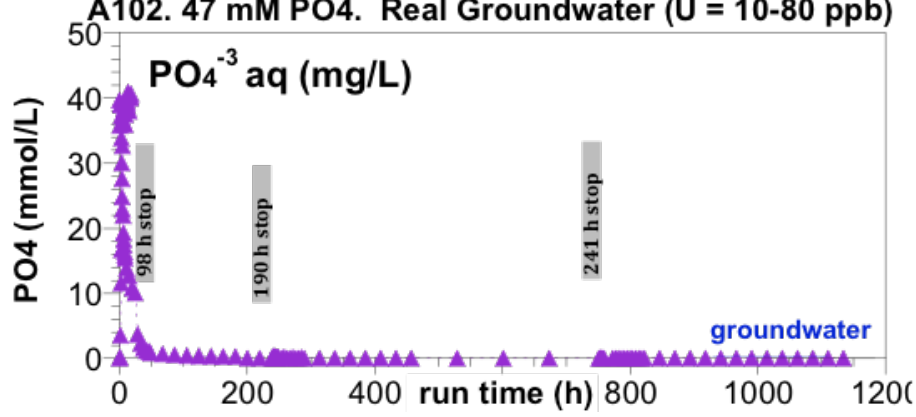

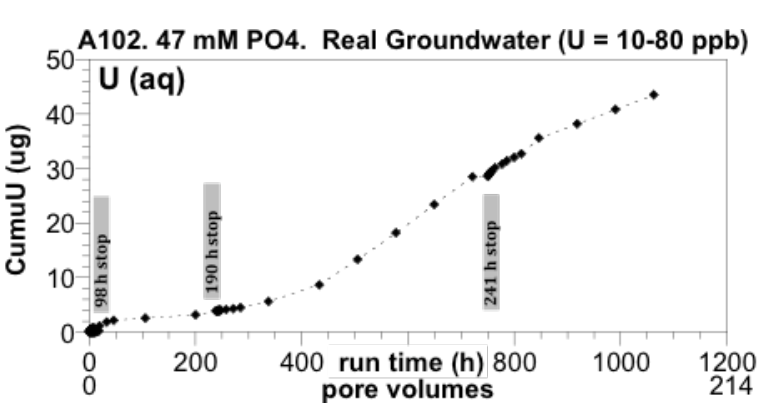
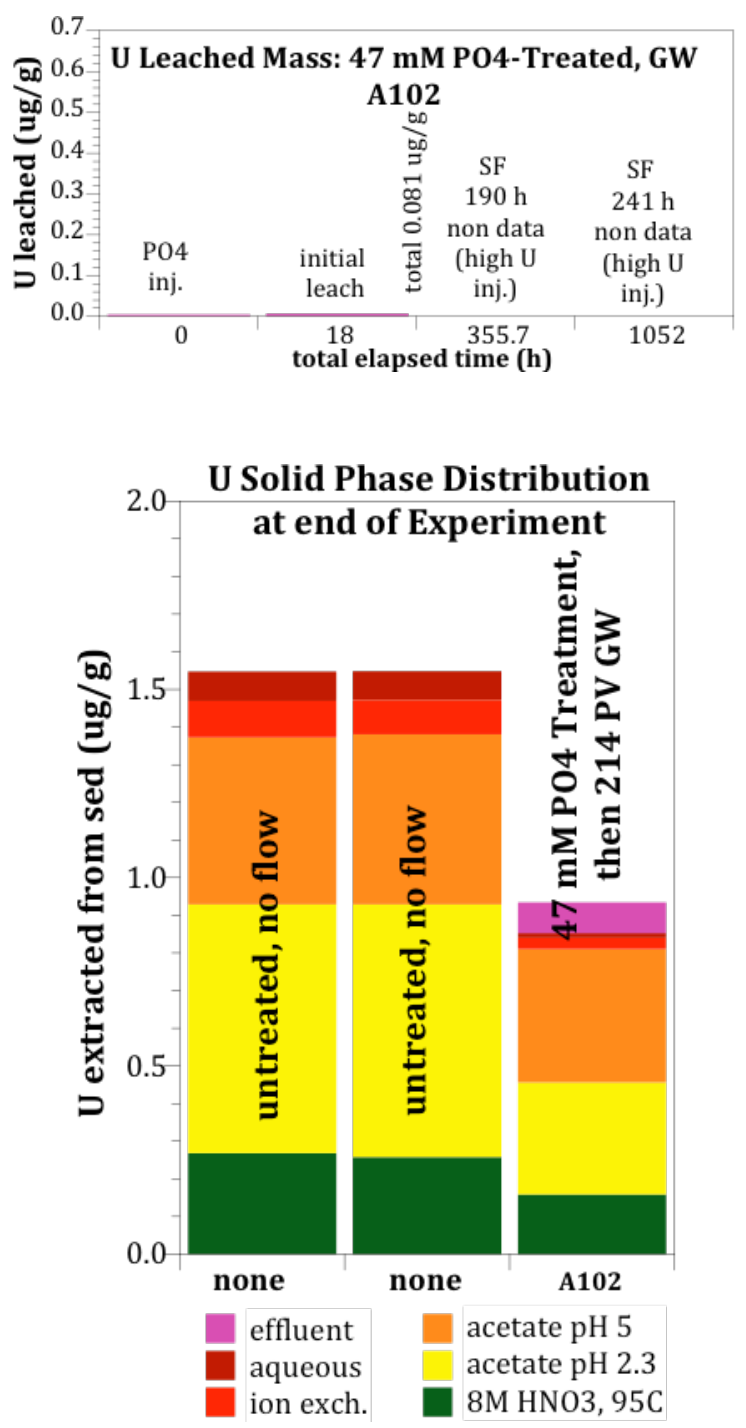

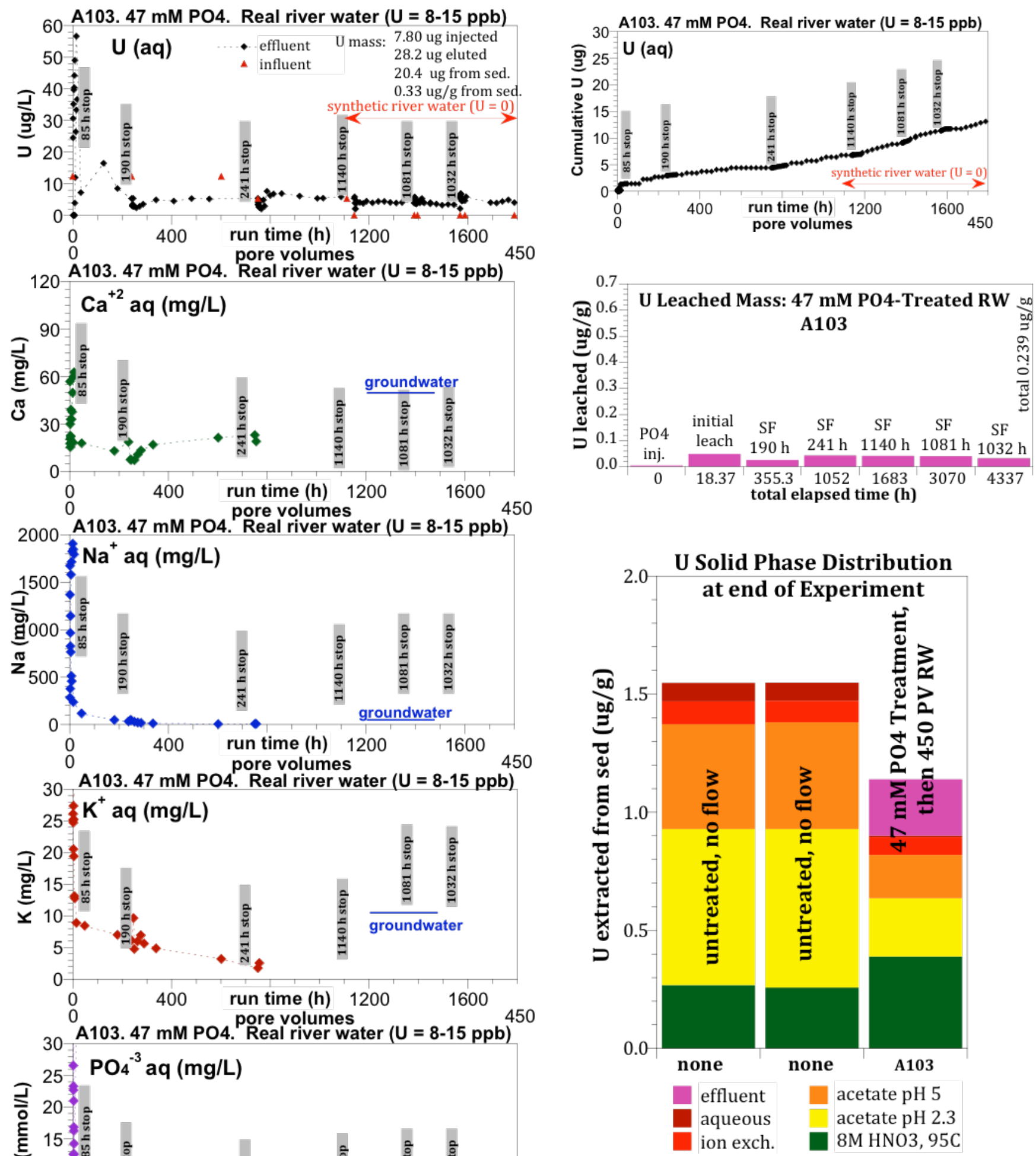

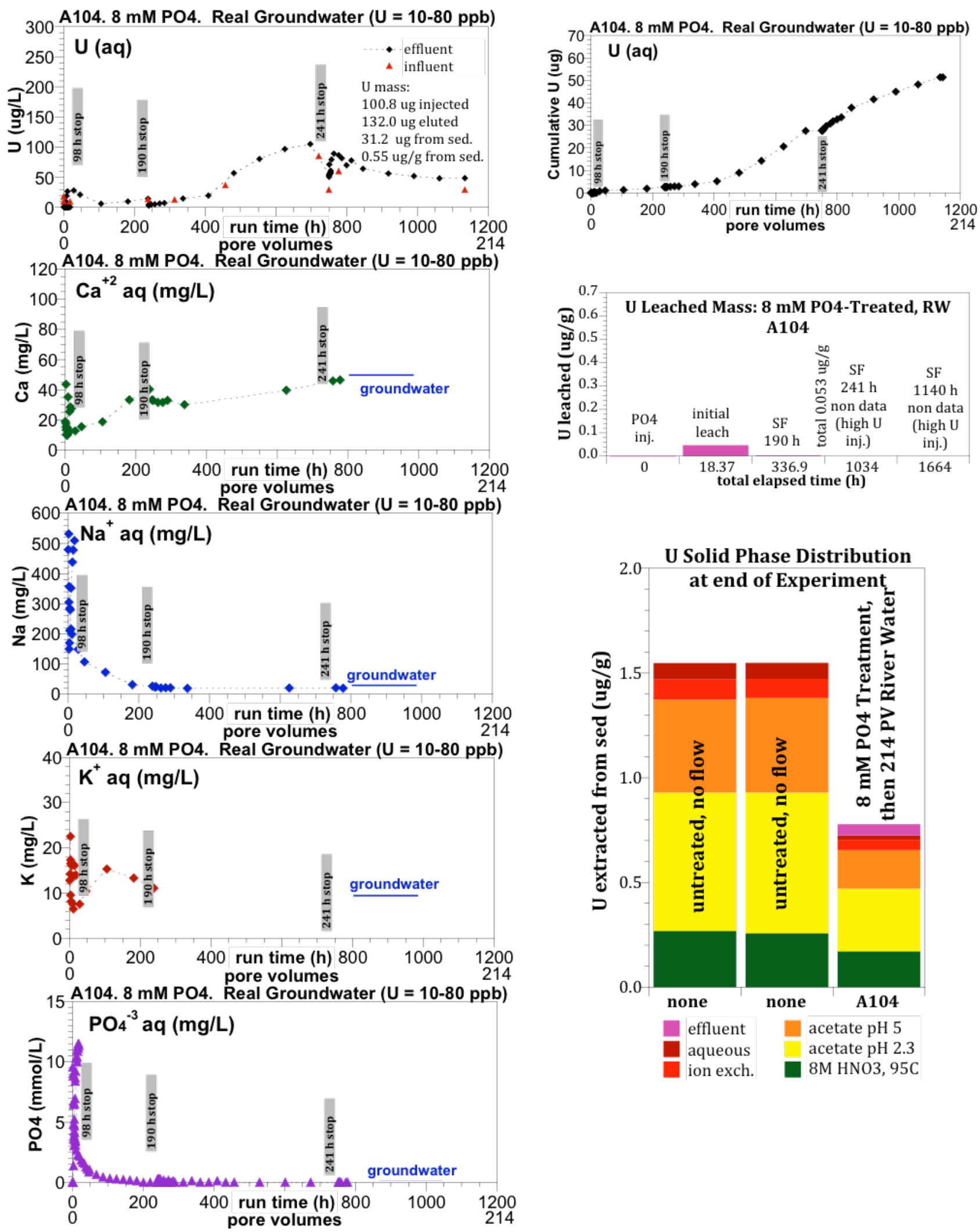

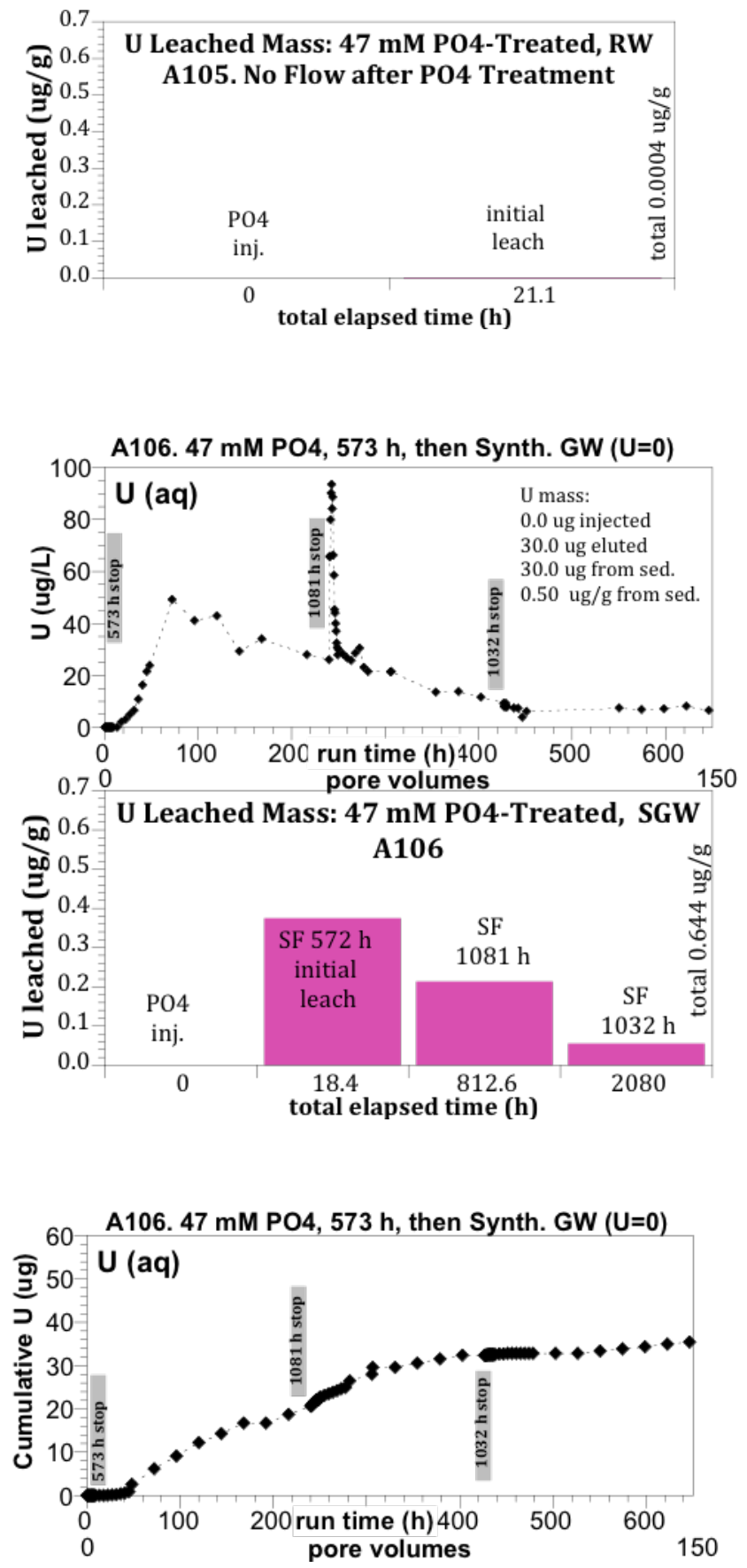
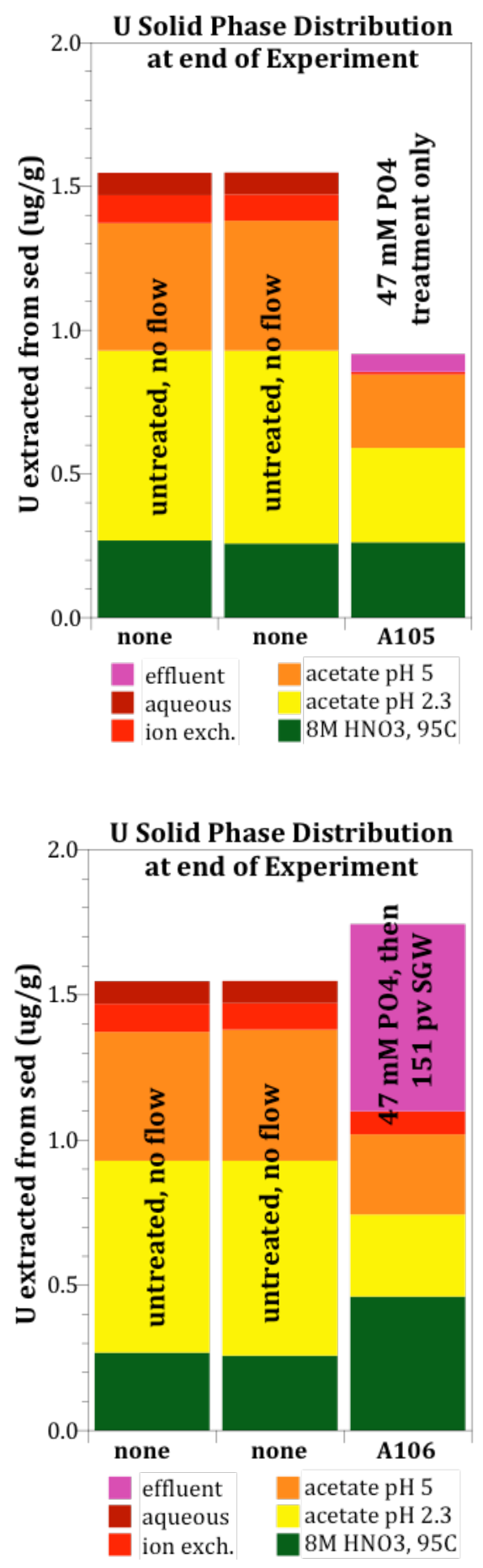

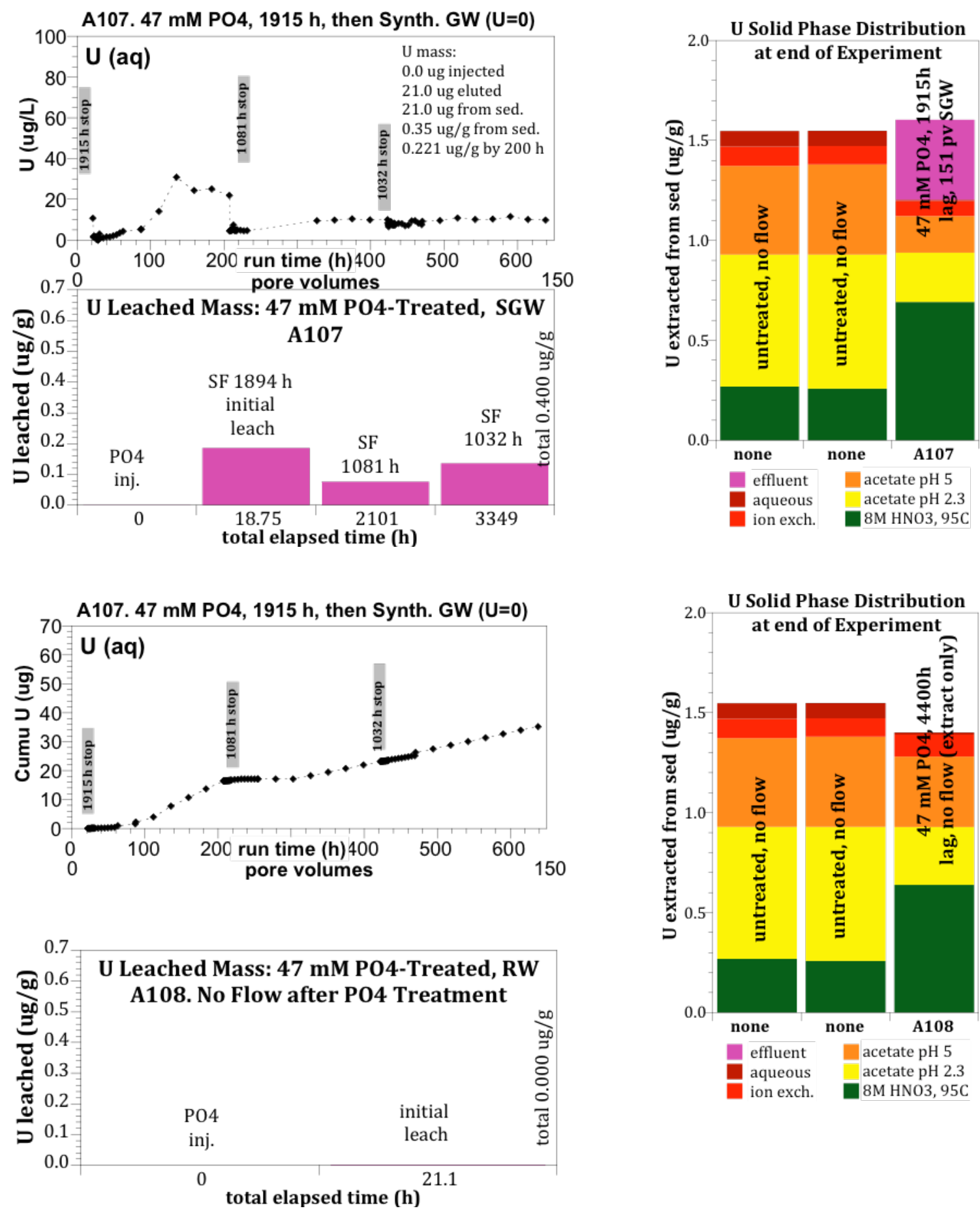

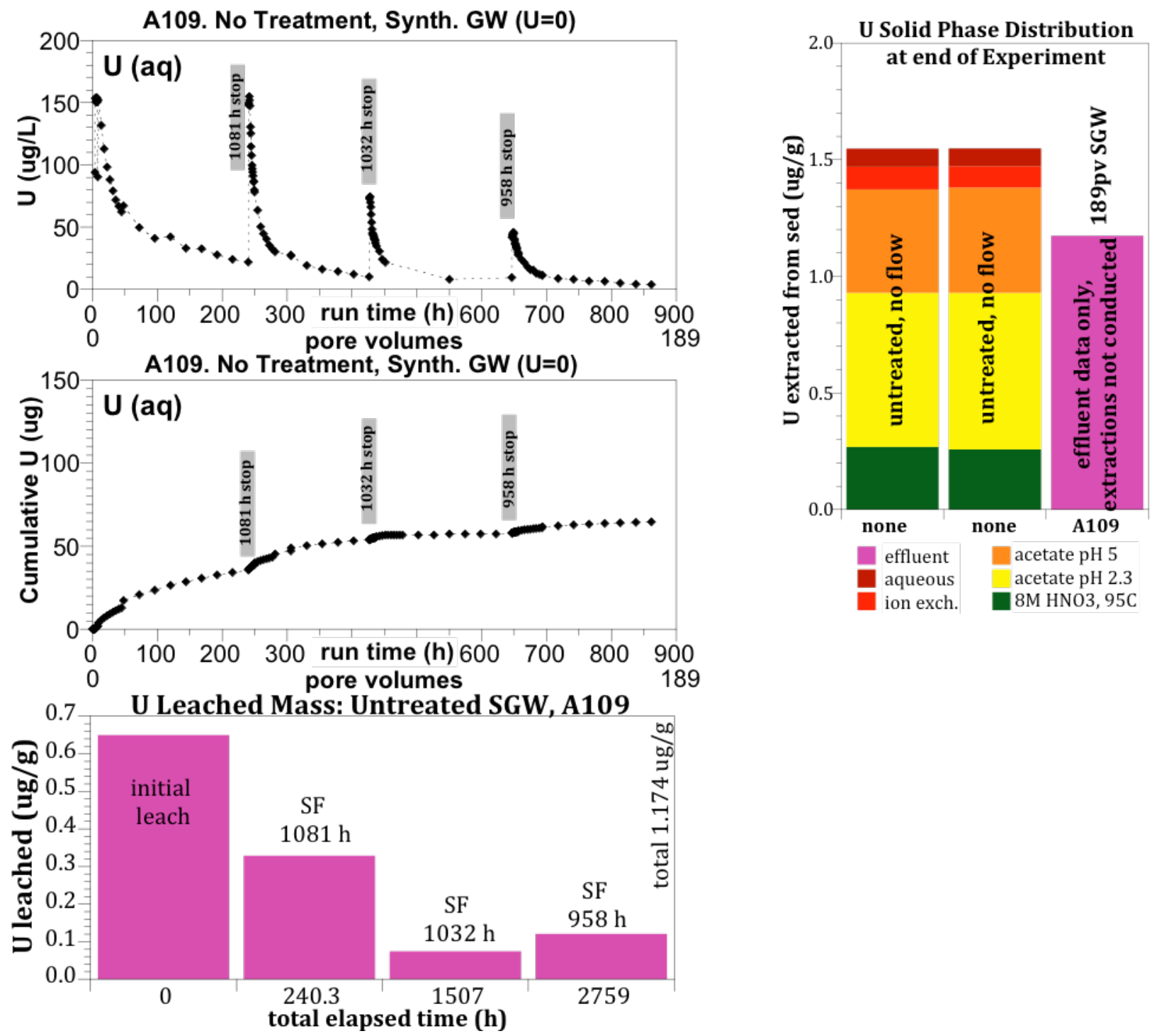
A110. 47mM PO4+3000ppm Xanth., 1100 h, Synth GW

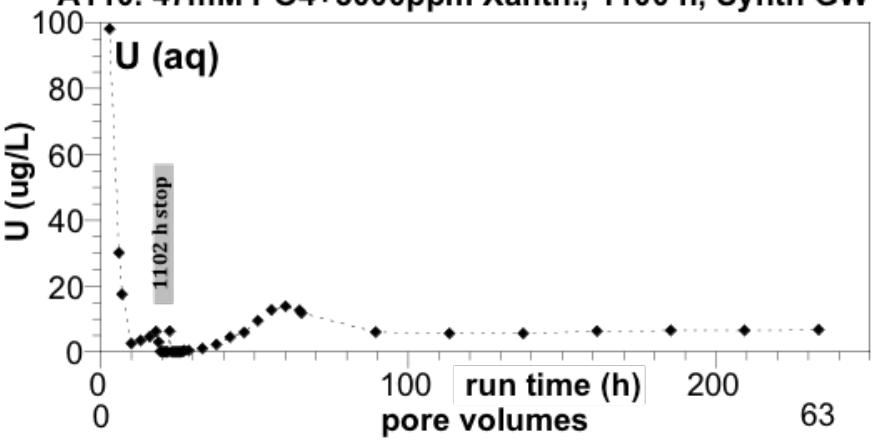

A110. 47mM PO4+3000ppm Xanth., 1100 h, Synth GW

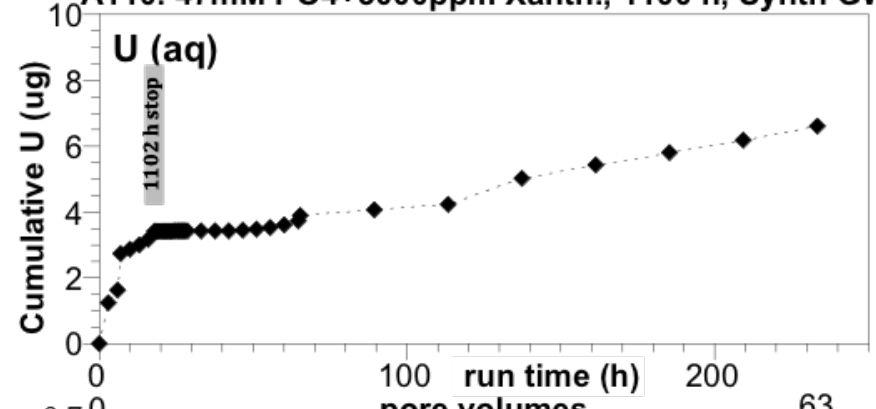

pore volumes

63

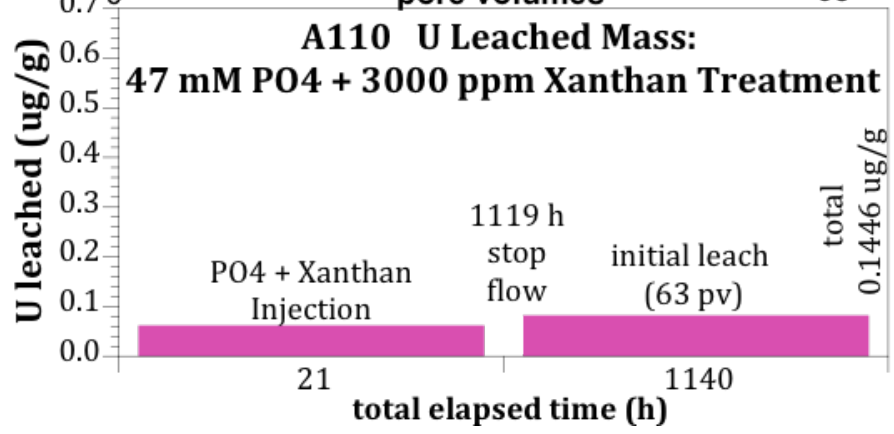

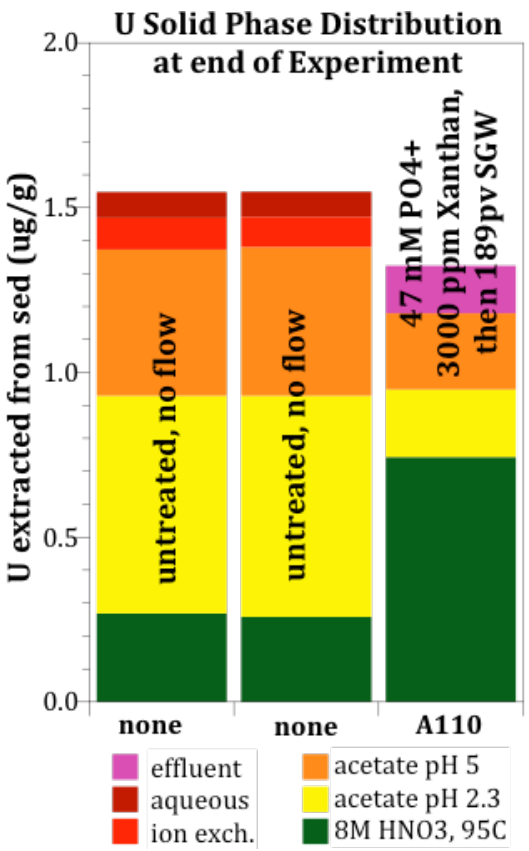



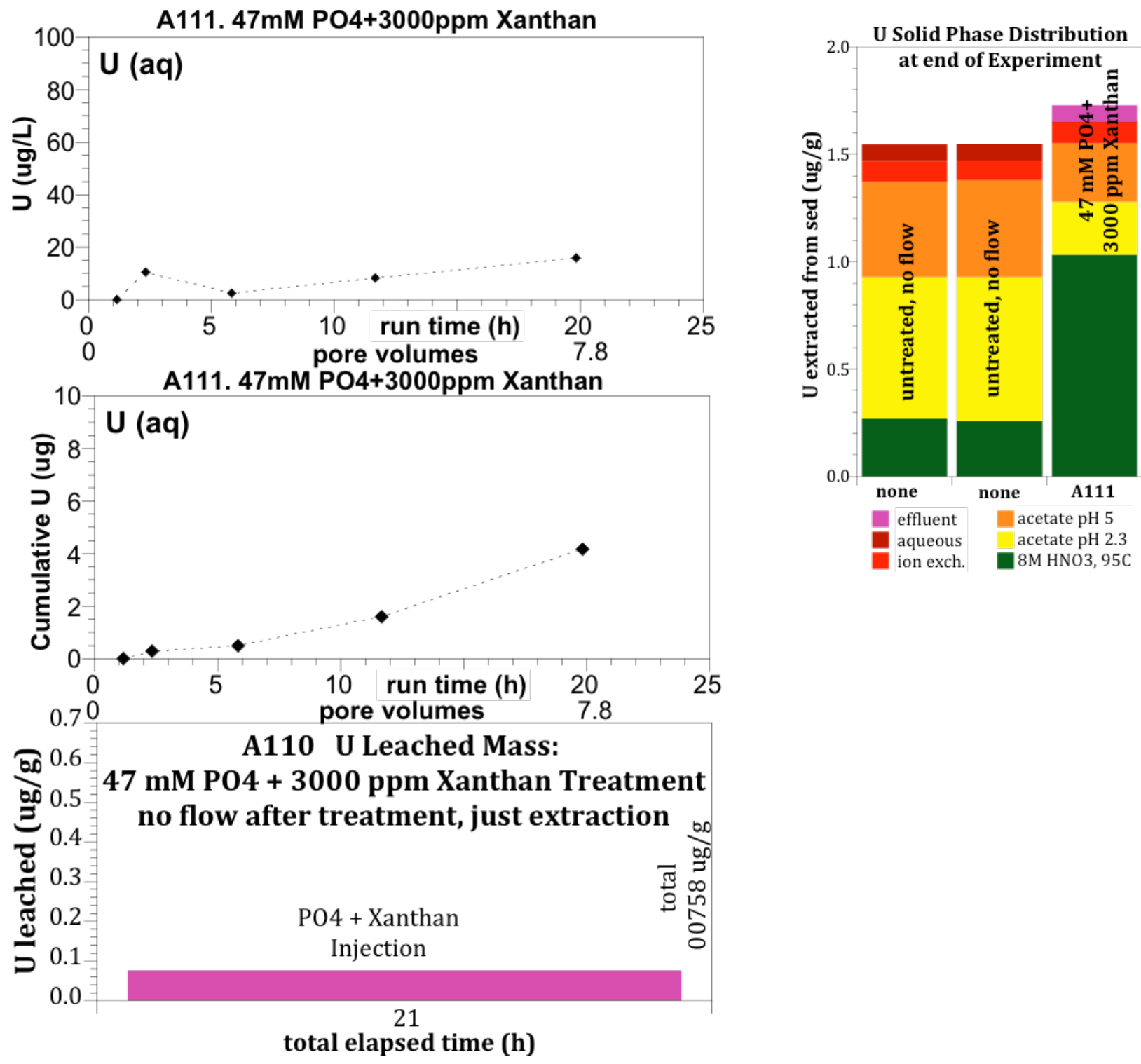

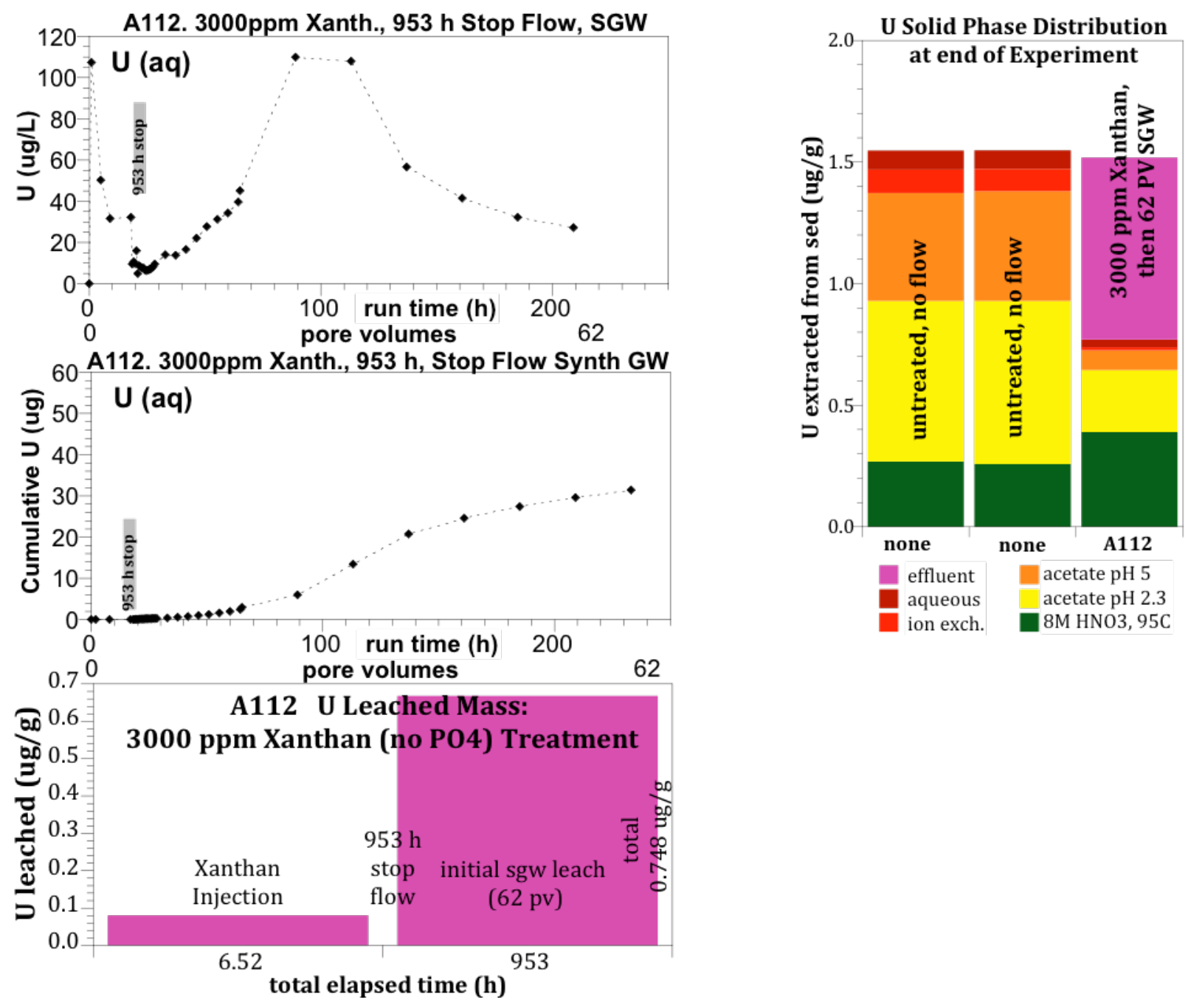

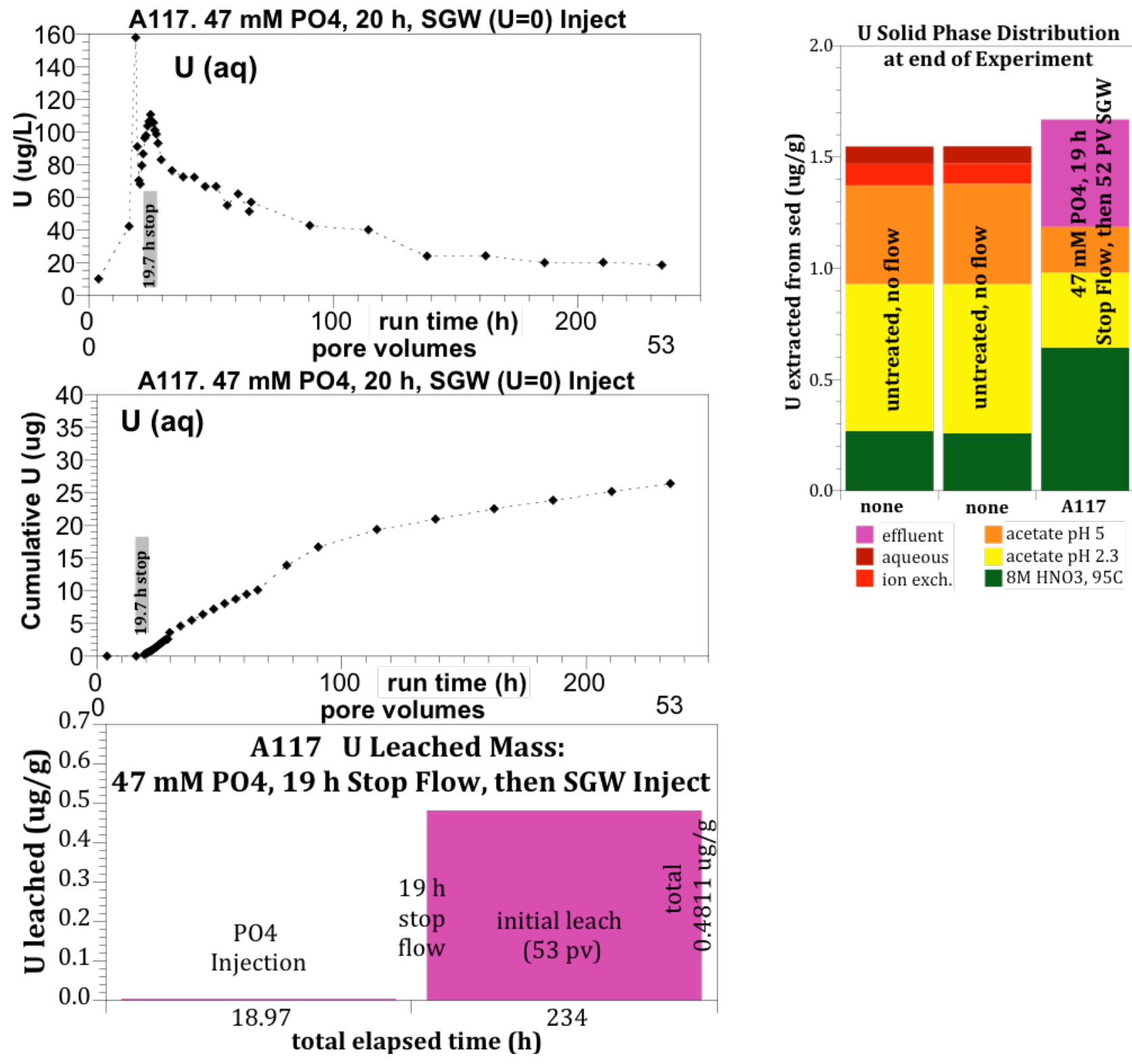

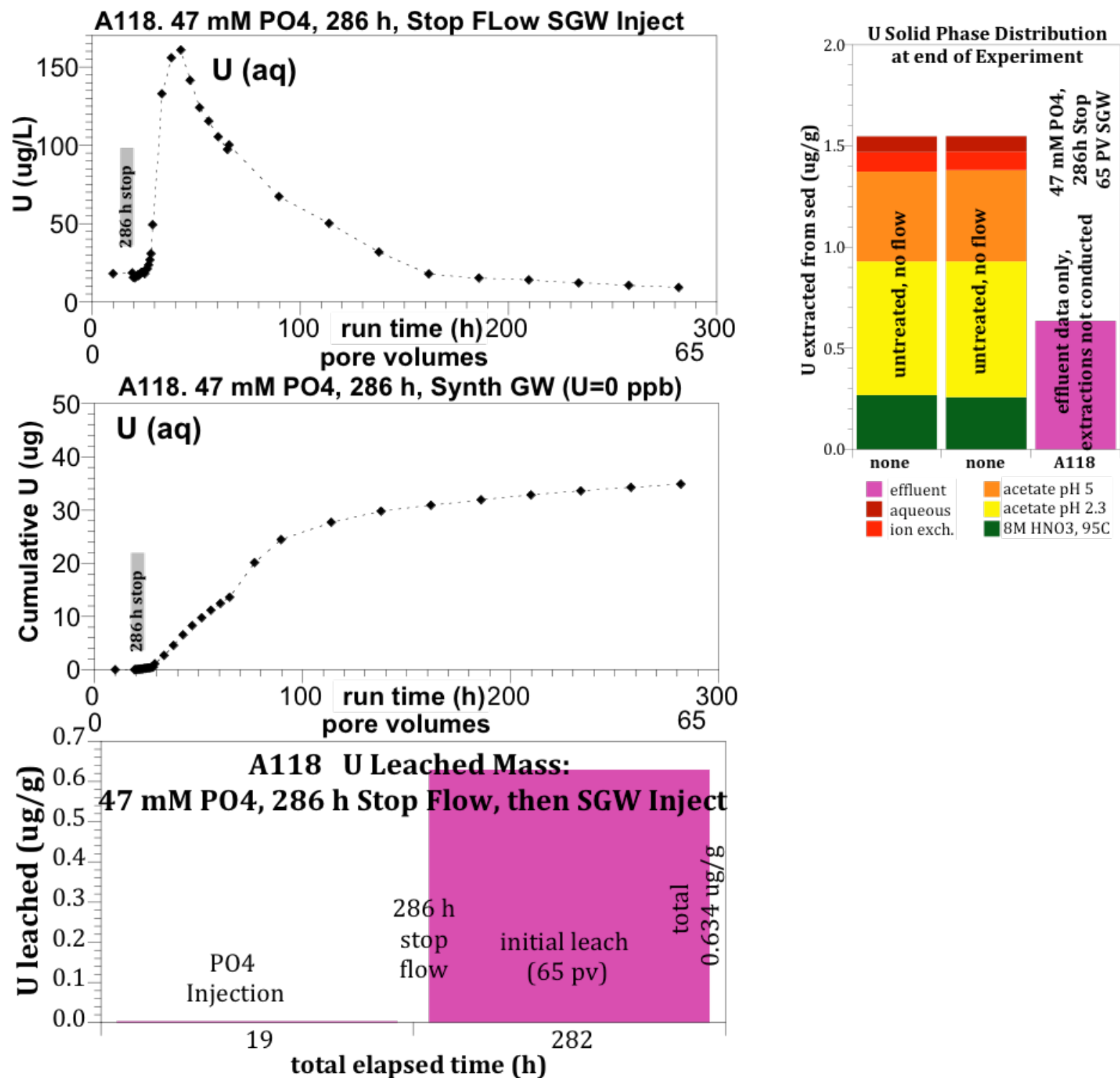
A119. 47 mM PO4, 286 h, Stop Flow Real GW (U=0.08ppb)

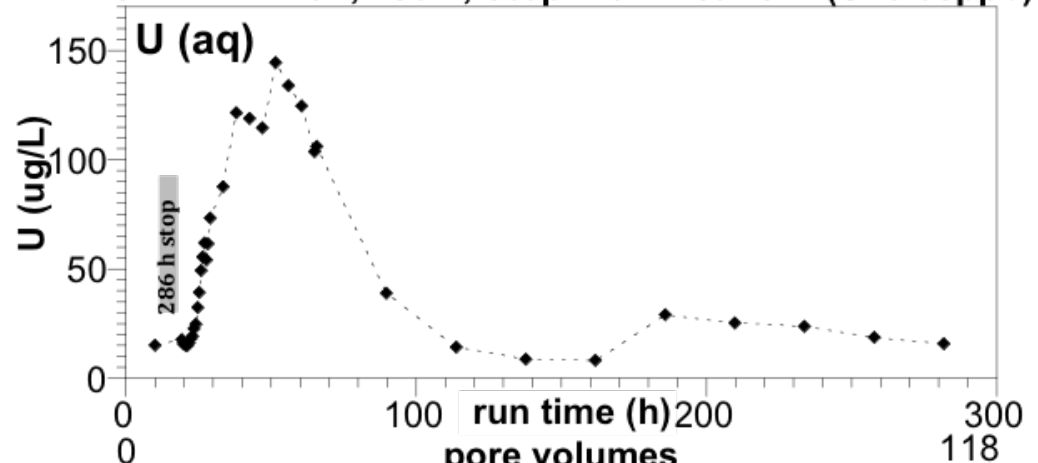

A119. 47 mM PO4, 286 h, Stop Flow Real GW (U=0.08ppb)
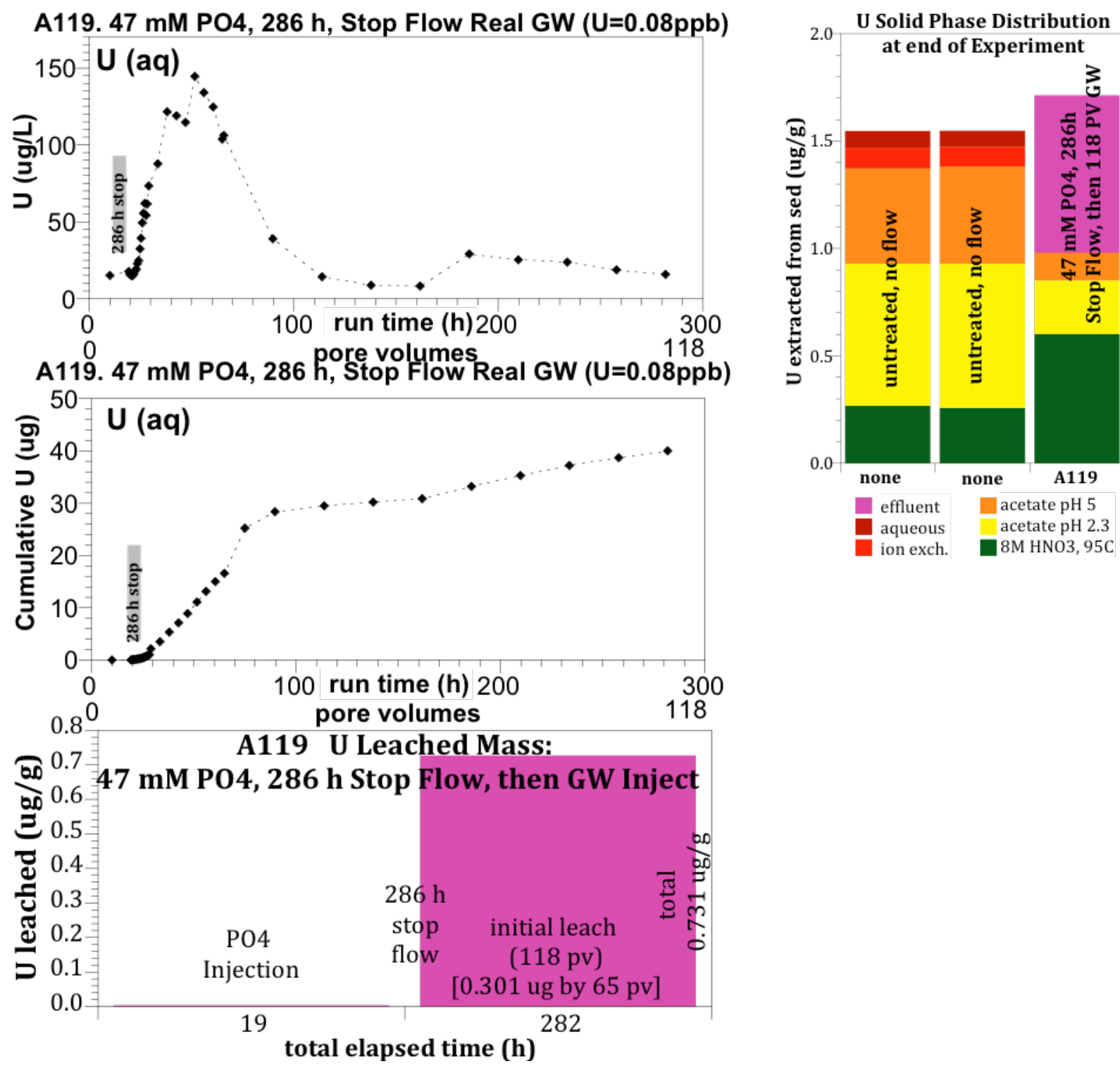
Appendix C

Phosphate Infiltration Experiments 



\section{Appendix C}

\section{Phosphate Infiltration Experiments}
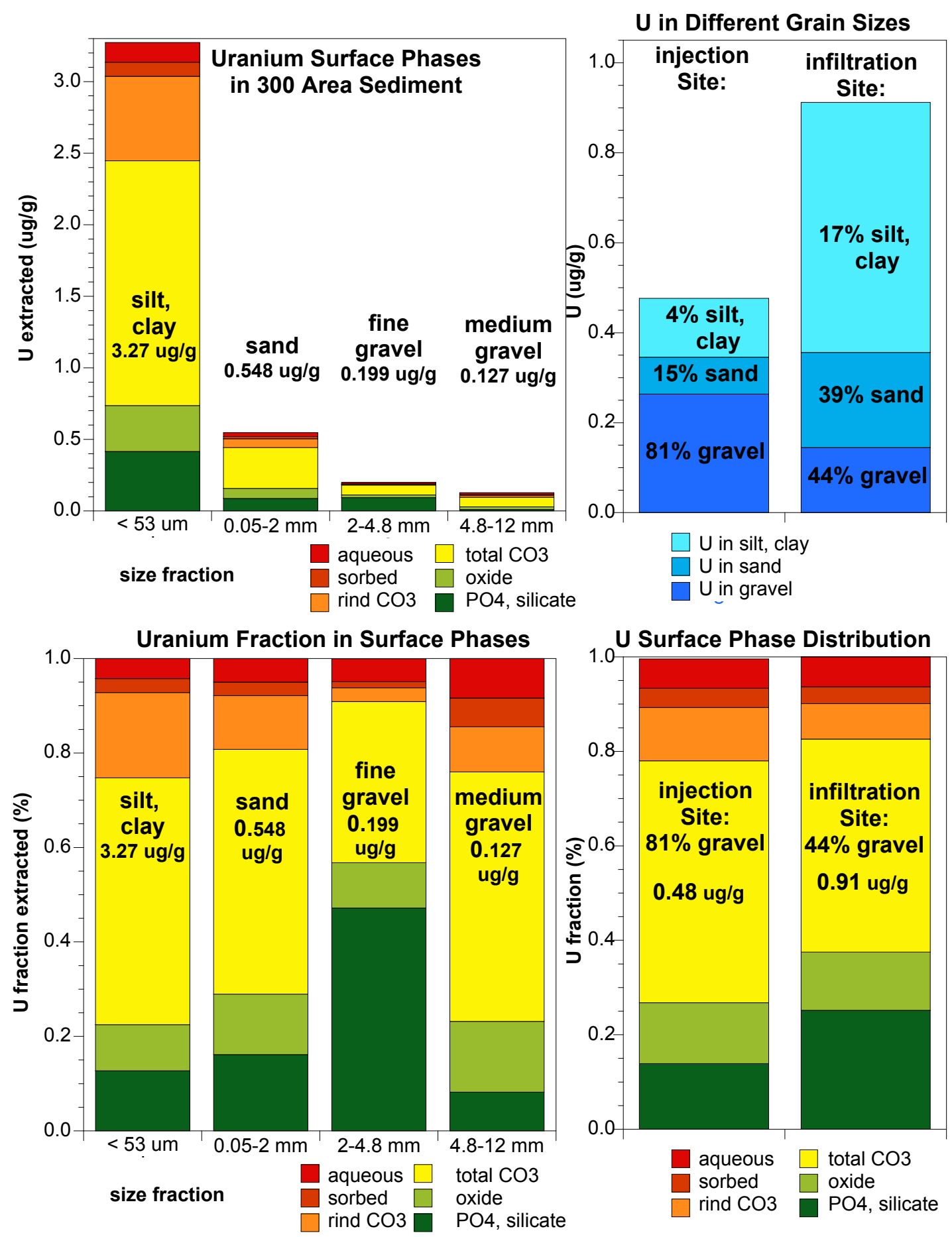

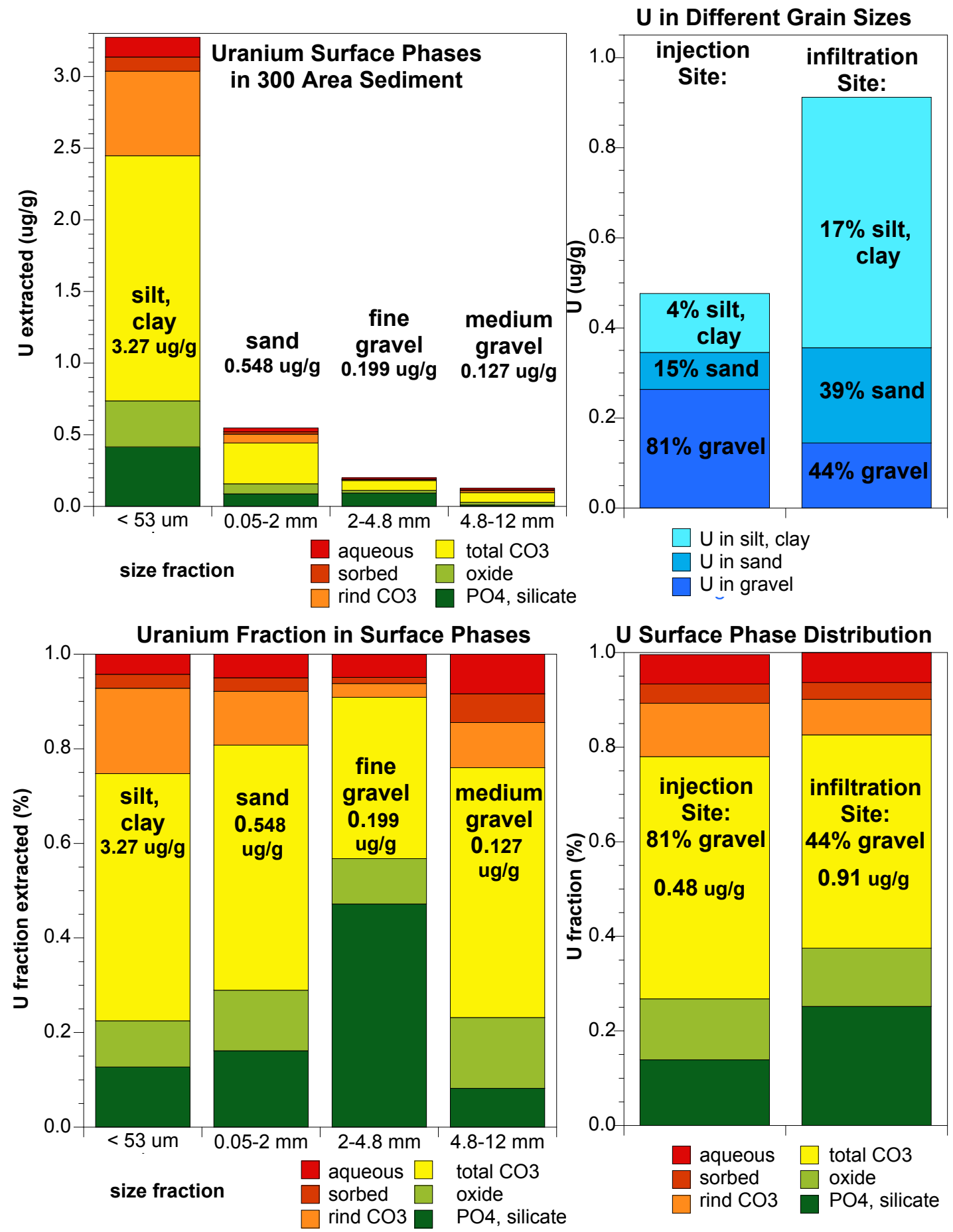
A69 Uranium in Water Infiltration into $100 \mathrm{~cm}$ Column

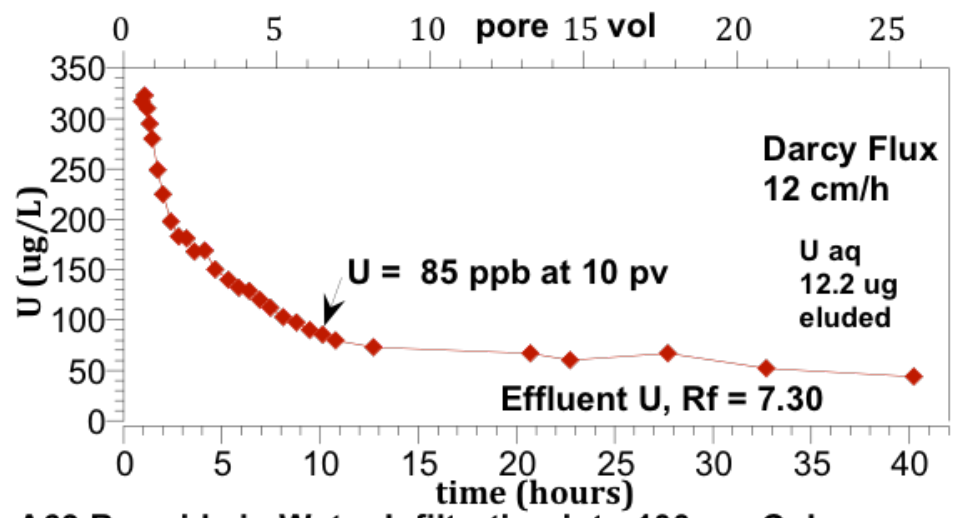

A69 Bromide in Water Infiltration into $100 \mathrm{~cm}$ Column

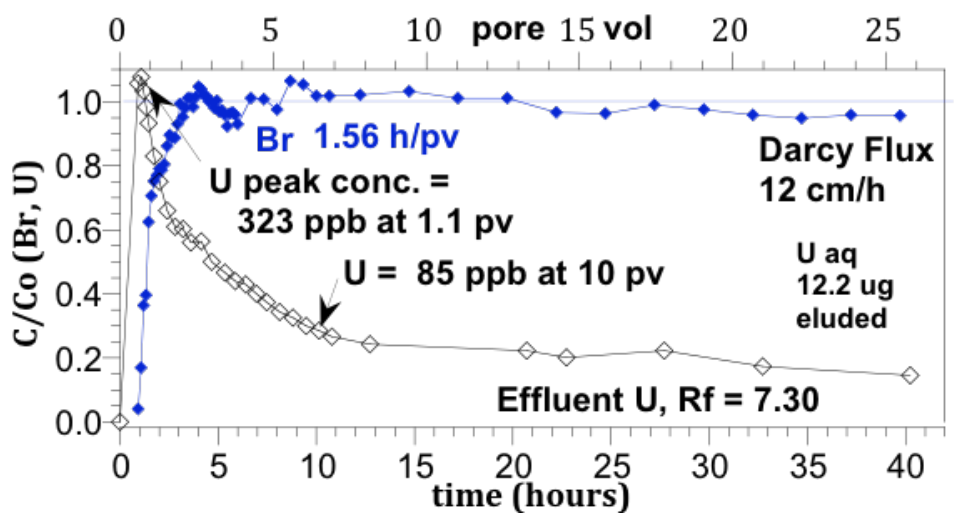

A70 Uranium in Water Infiltration into $100 \mathrm{~cm}$ Column
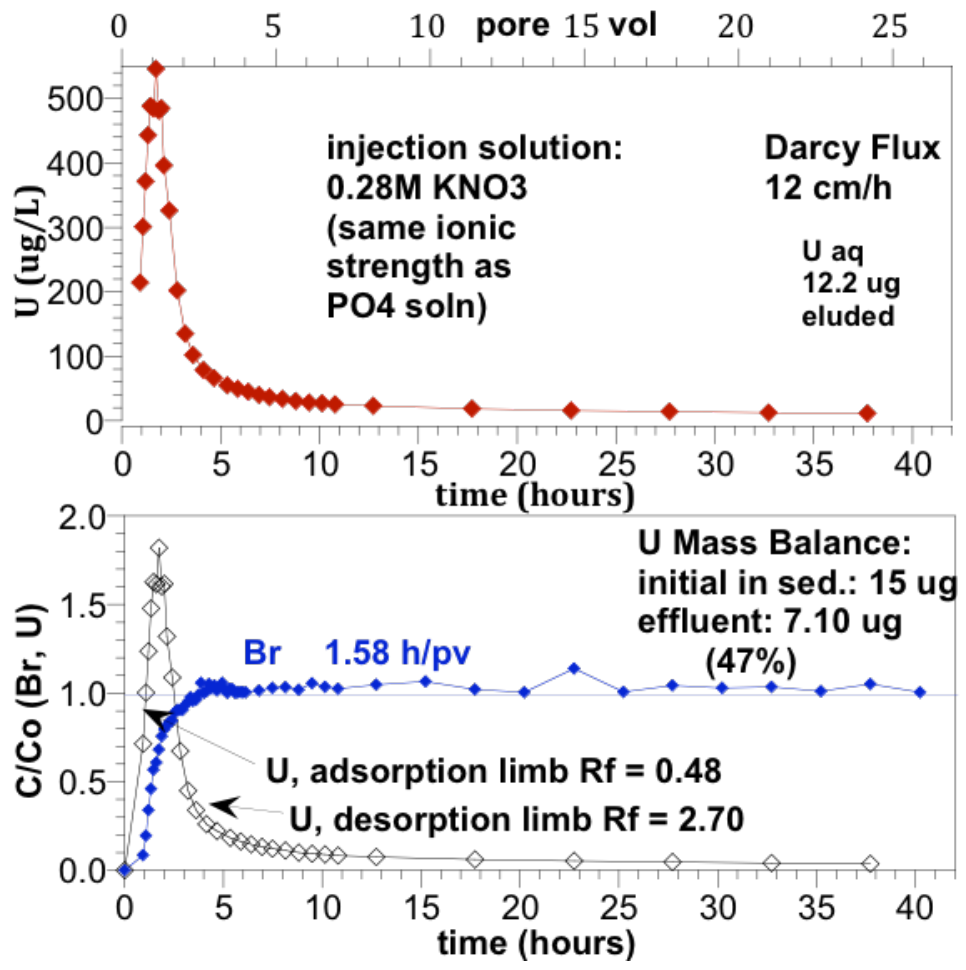
A71 polyPO4, Br Injection into $300 \mathrm{~cm}$ column, $10 \mathrm{~mL} / \mathrm{min}$

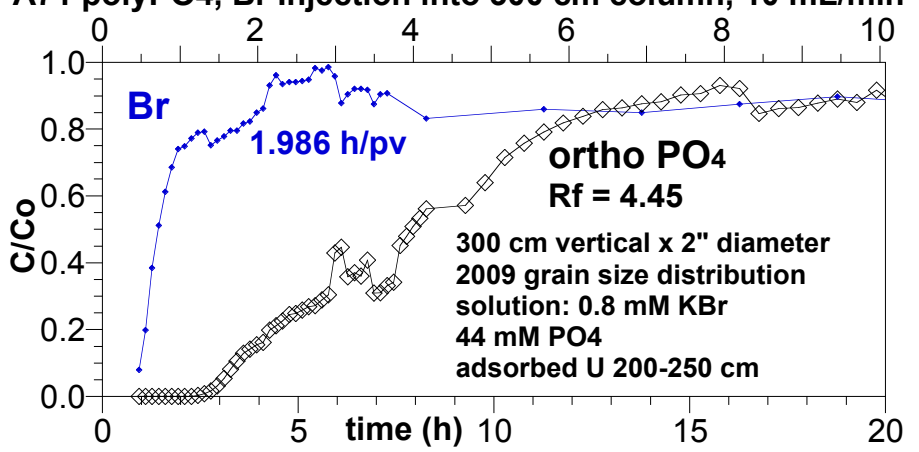

$\mathrm{U}$ for PolyPO4 Infiltration in $3 \mathrm{~m}$ column, $10 \mathrm{~mL} / \mathrm{min}$ (A71)

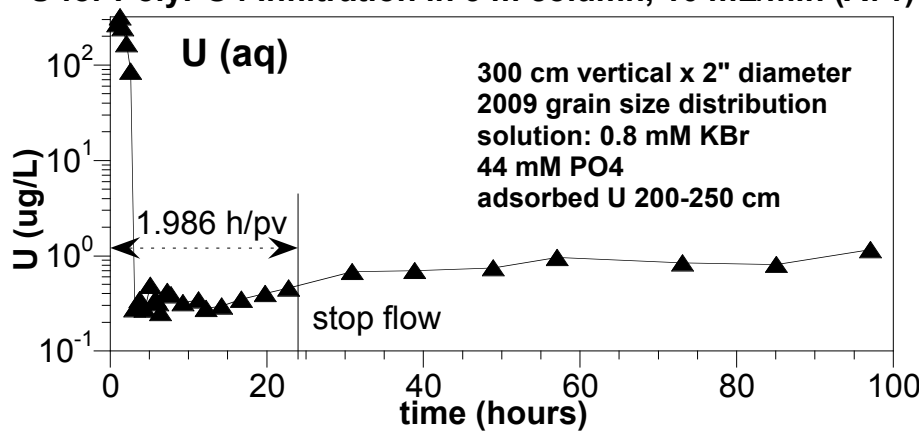

$\mathrm{U}$ for PolyPO4 Infiltration in $3 \mathrm{~m}$ column, $10 \mathrm{~mL} / \mathrm{min}$ (A71)

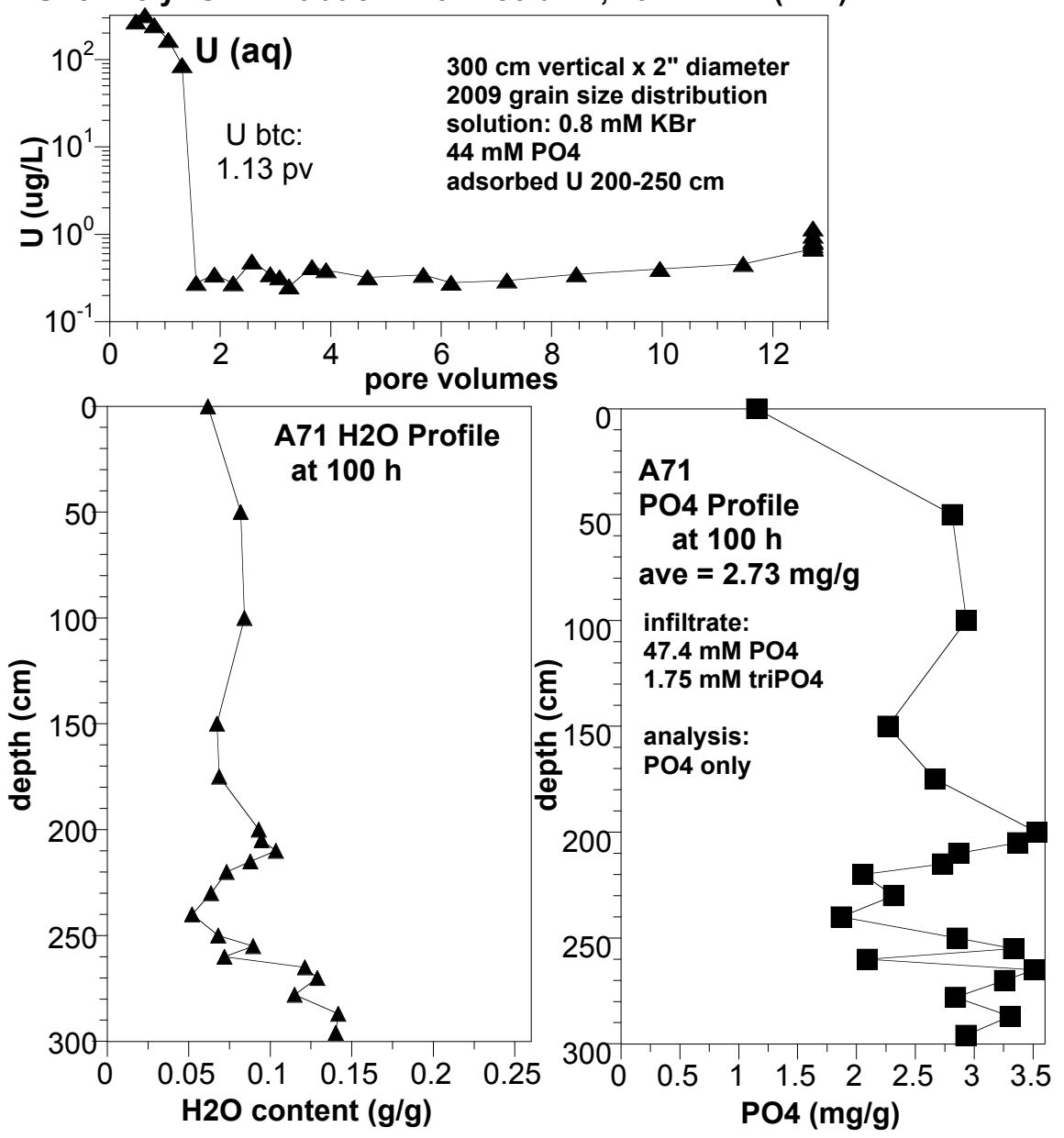


A72 polyPO4, Br Injection into $300 \mathrm{~cm}$ column, $4.35 \mathrm{~mL} / \mathrm{mir}$

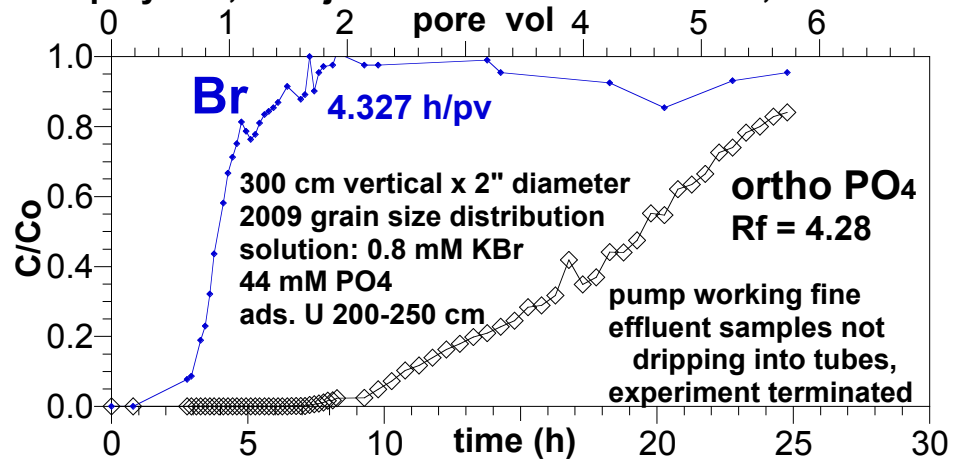

A72 polyPO4, Br Injection into $300 \mathrm{~cm}$ column, $4.35 \mathrm{~mL} / \mathrm{min}$

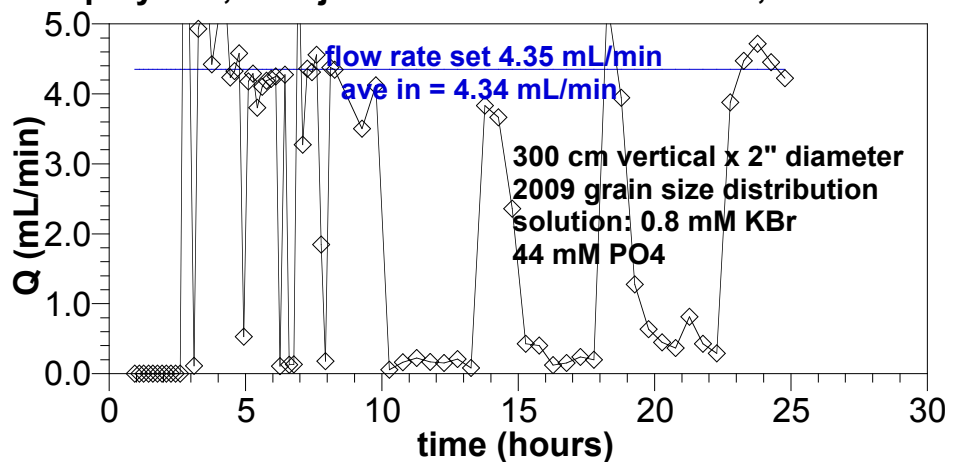


A73 polyPO4, Br Injection into $300 \mathrm{~cm}$ column, $2.1 \mathrm{~mL} / \mathrm{min}$

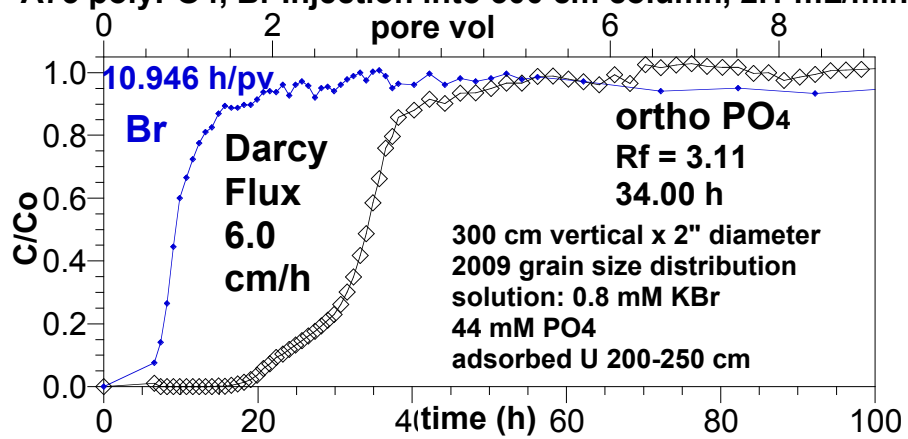

$\mathrm{U}$ for PolyPO4 Infiltration in $3 \mathrm{~m}$ column, $2.1 \mathrm{~mL} / \mathrm{min}$ (A73)

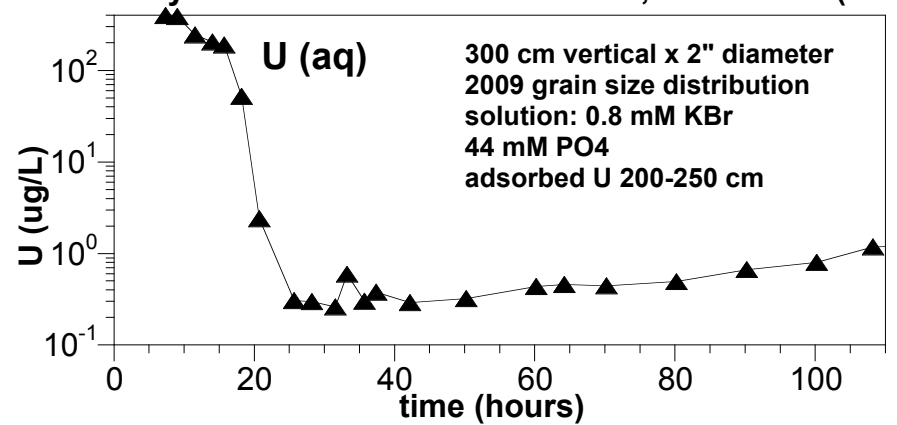

$\mathrm{U}$ for PolyPO4 Infiltration in $3 \mathrm{~m}$ column, $2.1 \mathrm{~mL} / \mathrm{min}$ (A73)
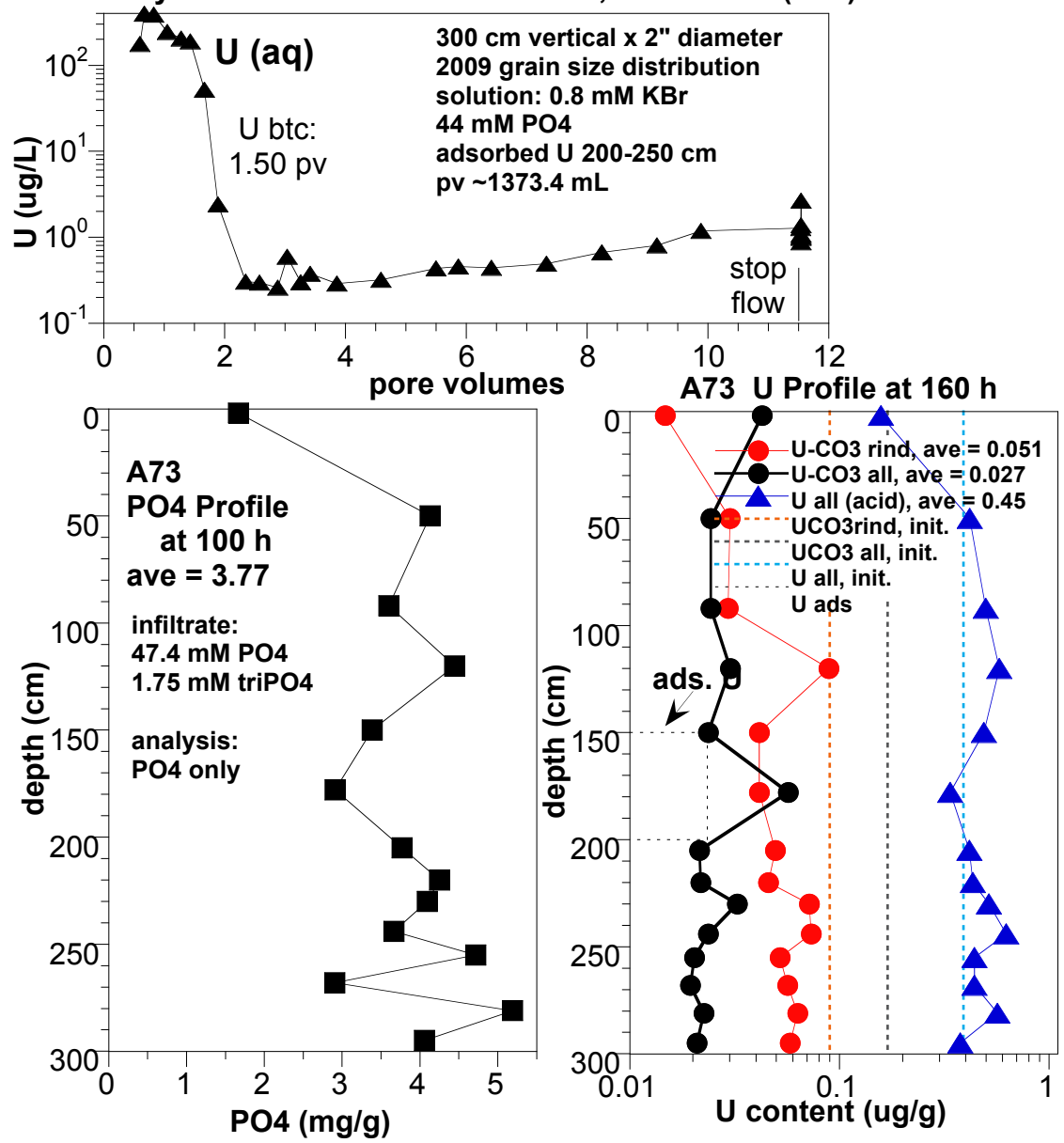
A74 polyPO4, Br Injection into $300 \mathrm{~cm}$ column, $1.0 \mathrm{~mL} / \mathrm{min}$

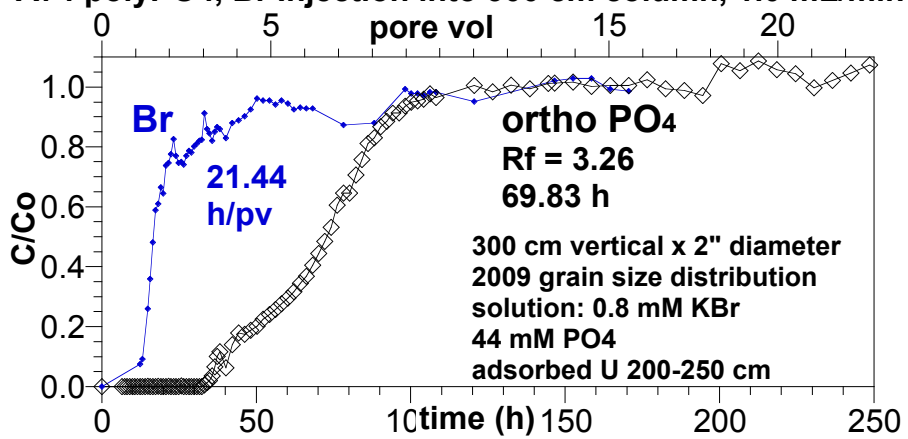

$\mathrm{U}$ for PolyPO4 Infiltration in $3 \mathrm{~m}$ column, $1.0 \mathrm{~mL} / \mathrm{min}$ (A74)

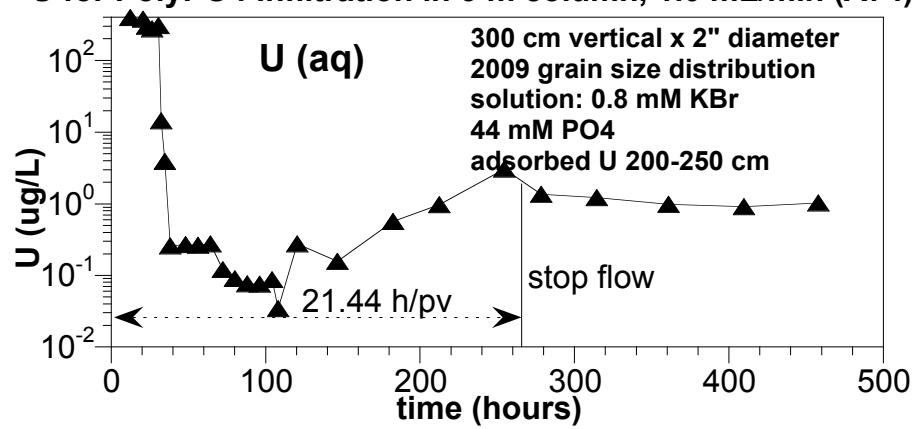

$\mathrm{U}$ for PolyPO4 Infiltration in $3 \mathrm{~m}$ column, $1.0 \mathrm{~mL} / \mathrm{min}$ (A74)

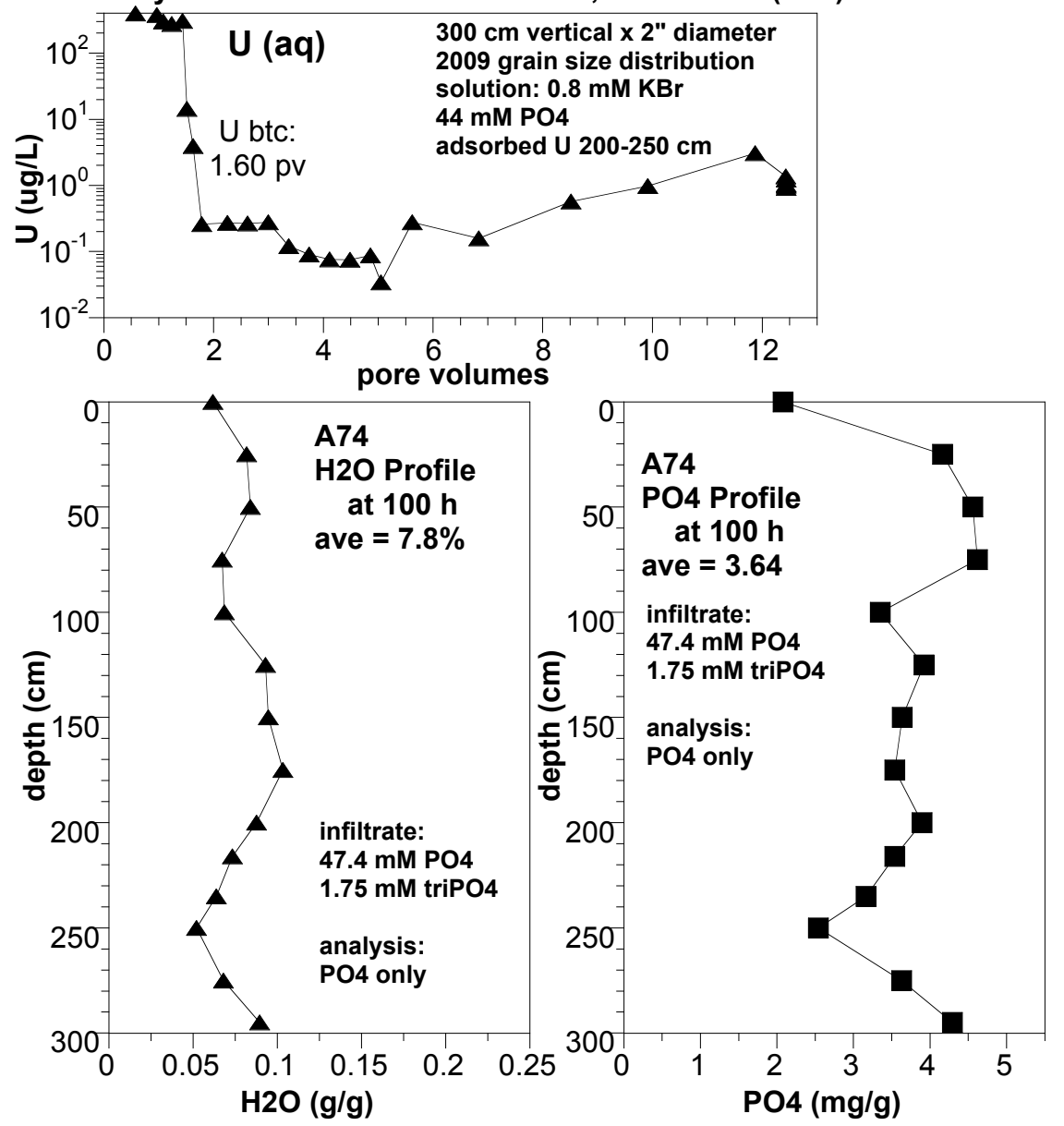

C.7 

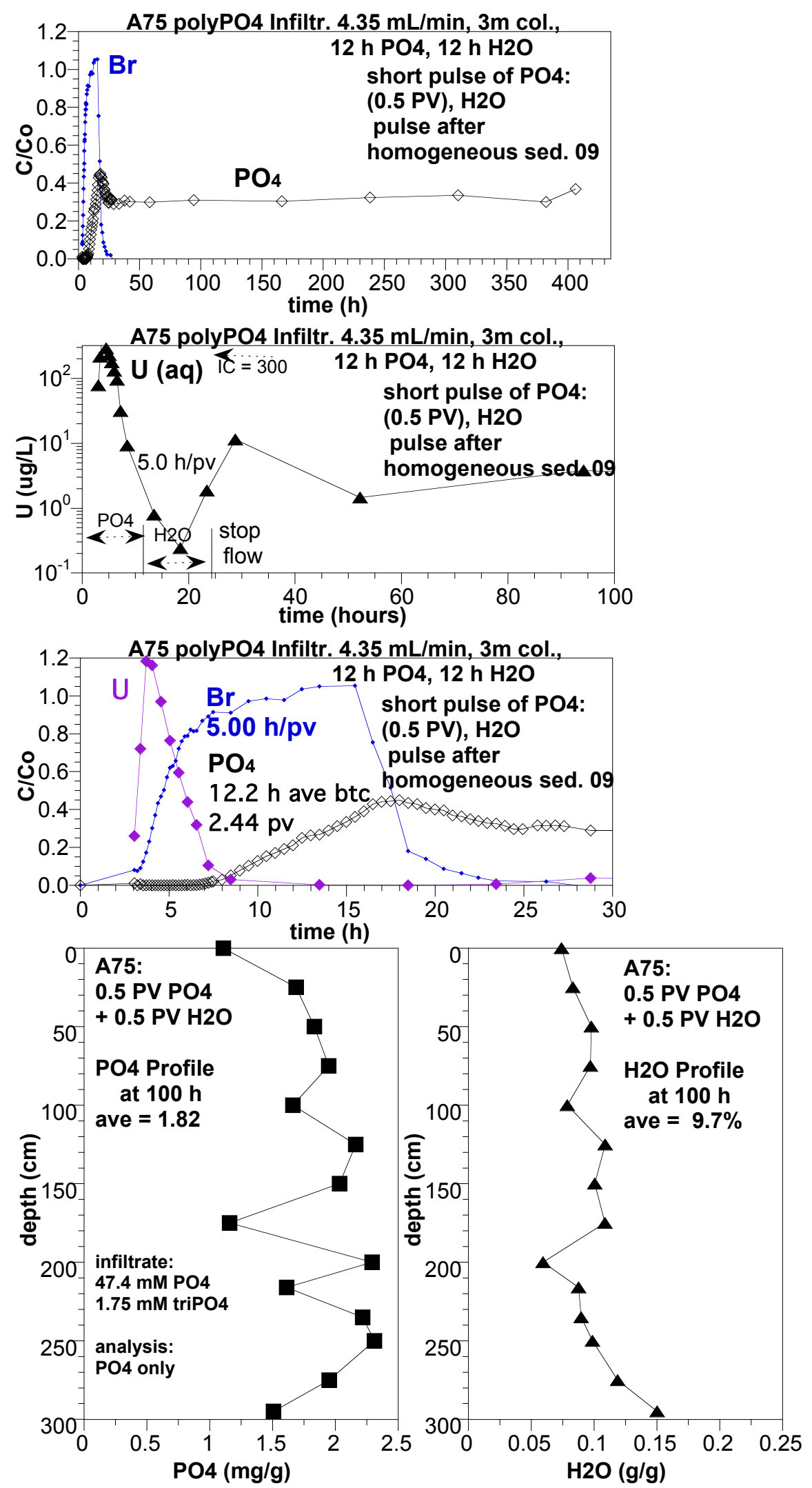


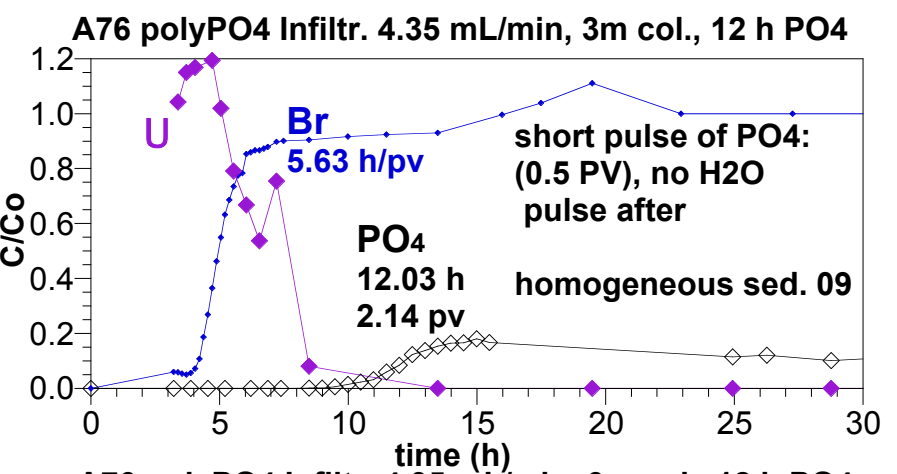

A76 polyPO4 Infiltr. $4.35 \mathrm{~mL} / \mathrm{min}, 3 \mathrm{~m}$ col., 12 h PO4

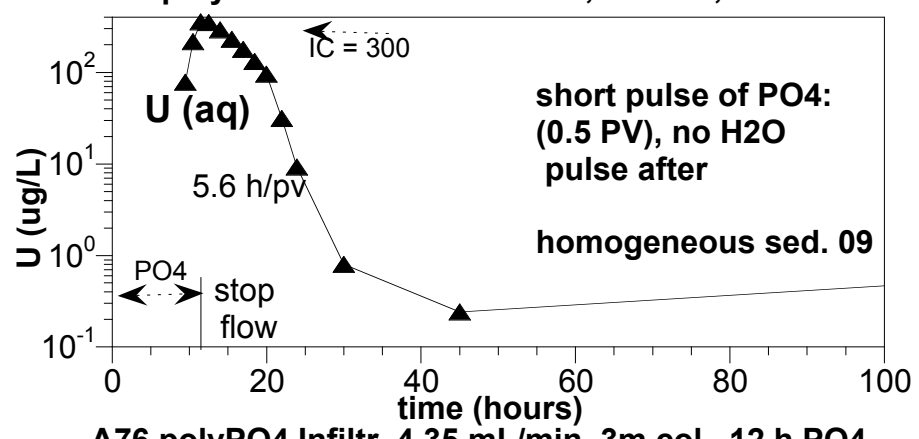

A76 polyPO4 Infiltr. 4.35 mL/min, 3m col., 12 h PO4
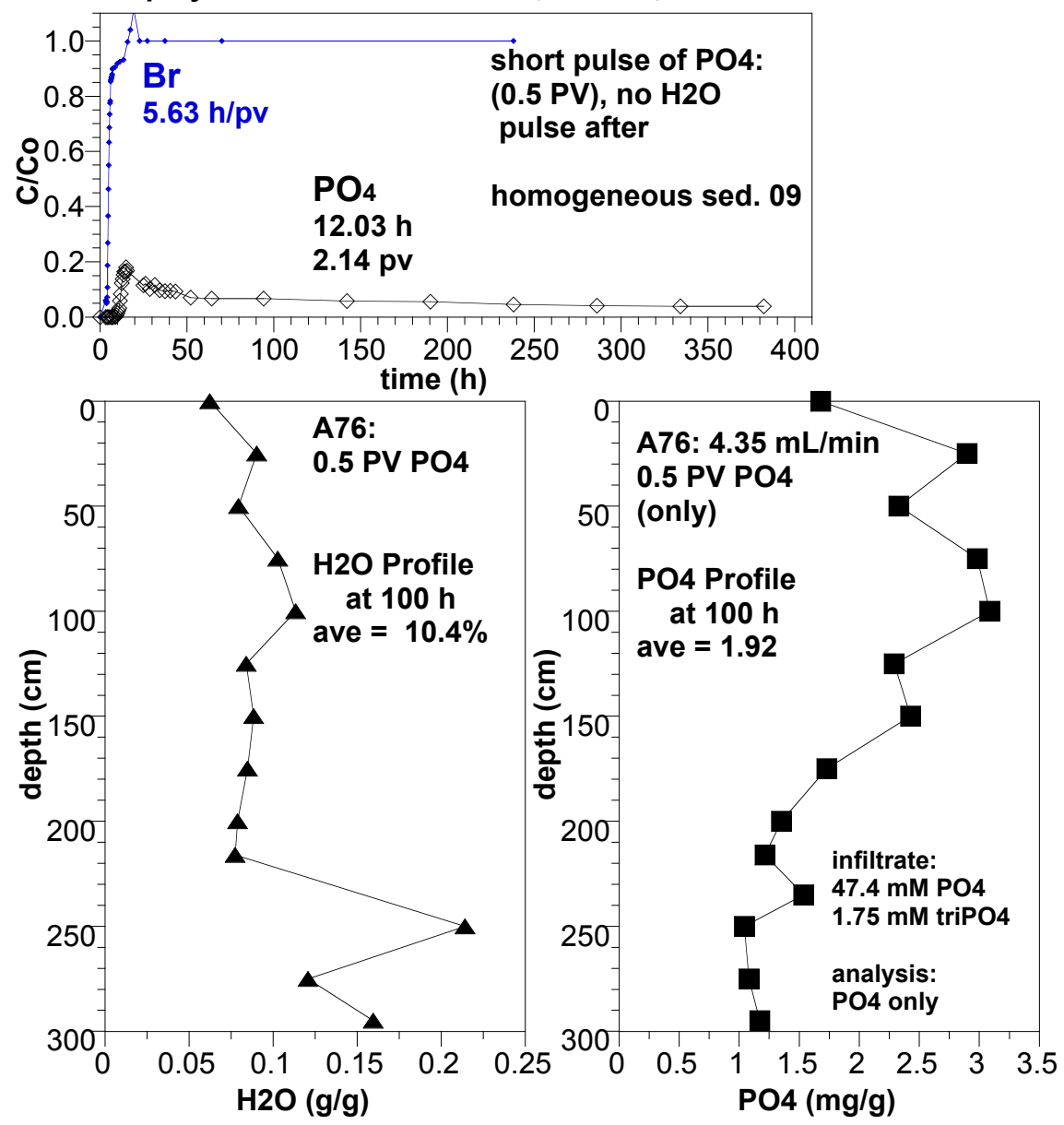

C.9 

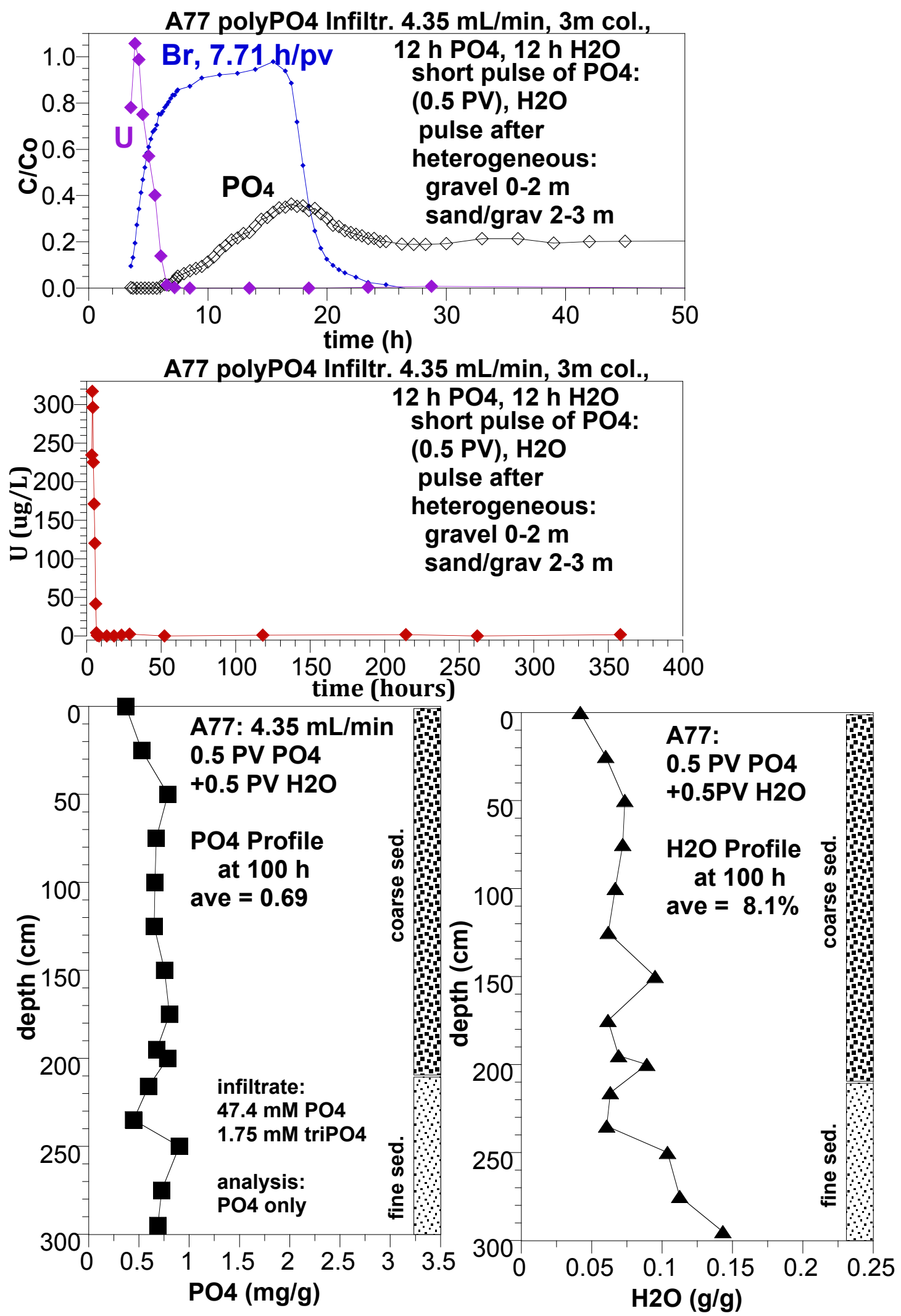
A78 polyPO4 Infiltr. $4.35 \mathrm{~mL} / \mathrm{min}, 3 \mathrm{~m}$ col., 12 h PO4

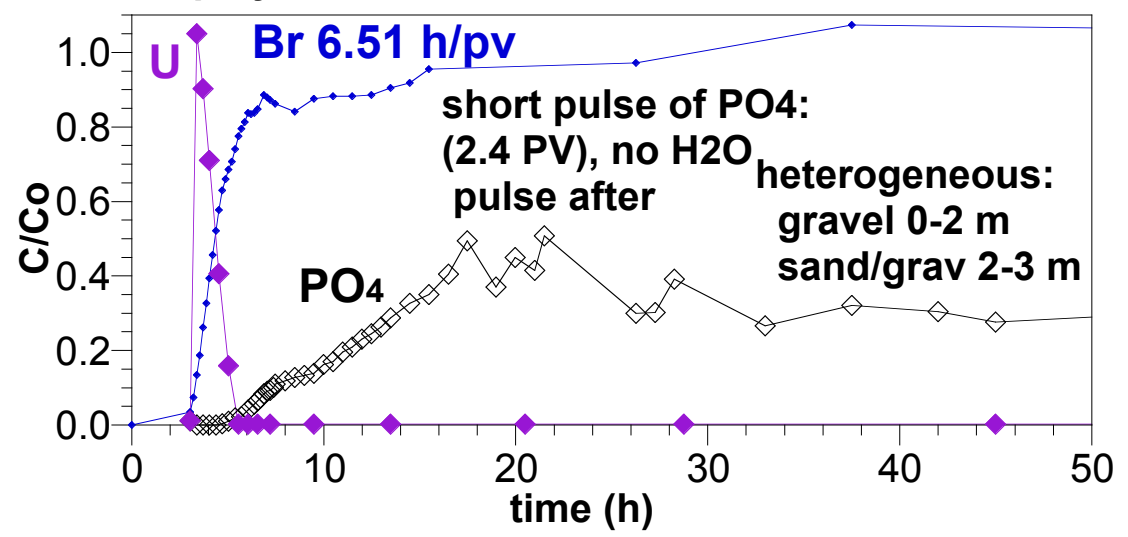

A78 polyPO4 Infiltr. $4.35 \mathrm{~mL} / \mathrm{min}, 3 \mathrm{~m}$ col., 12 h PO4
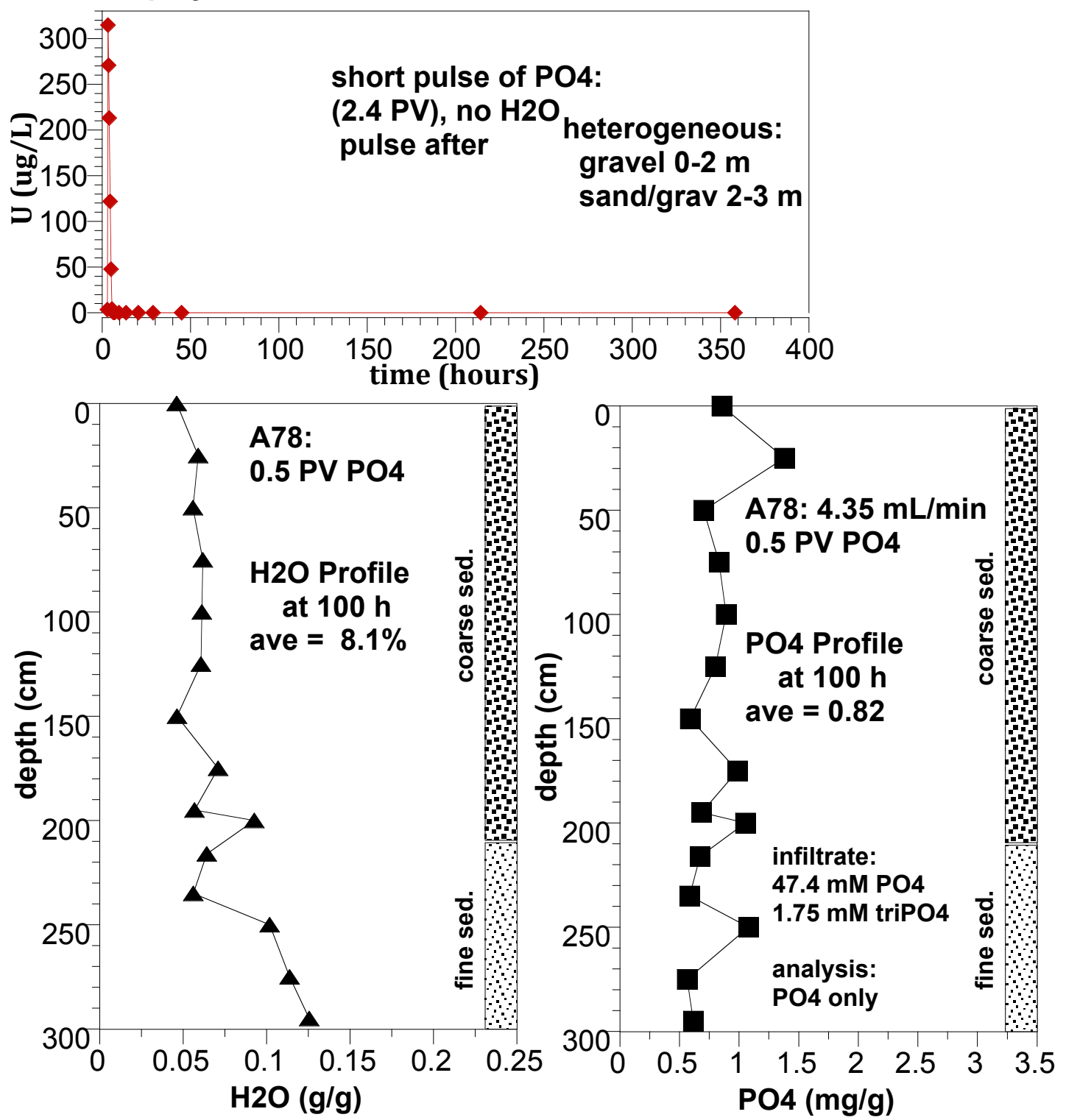

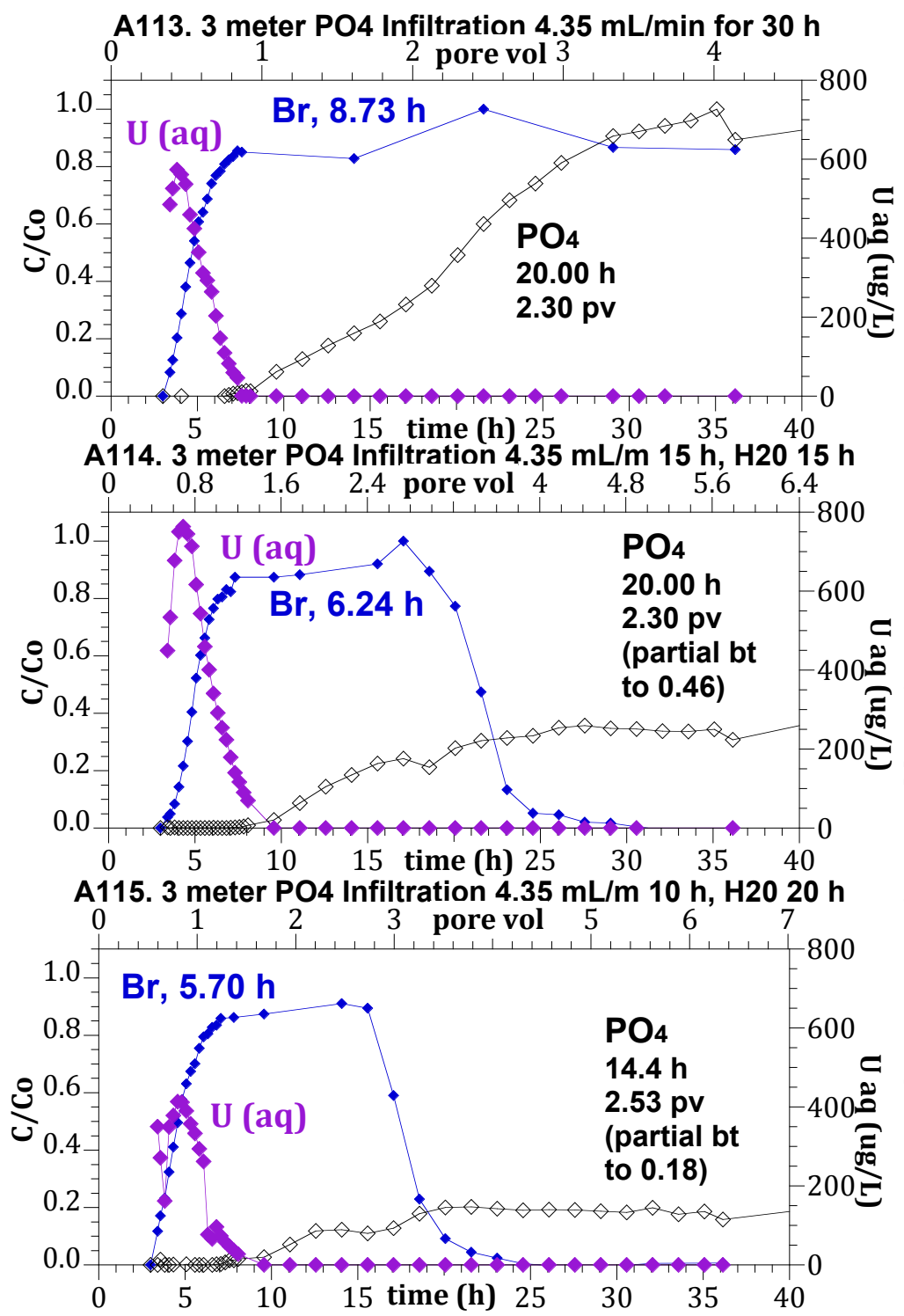

A116. 3 meter PO4 Infiltration 4.35 mL/m 10 h, H20 20 h

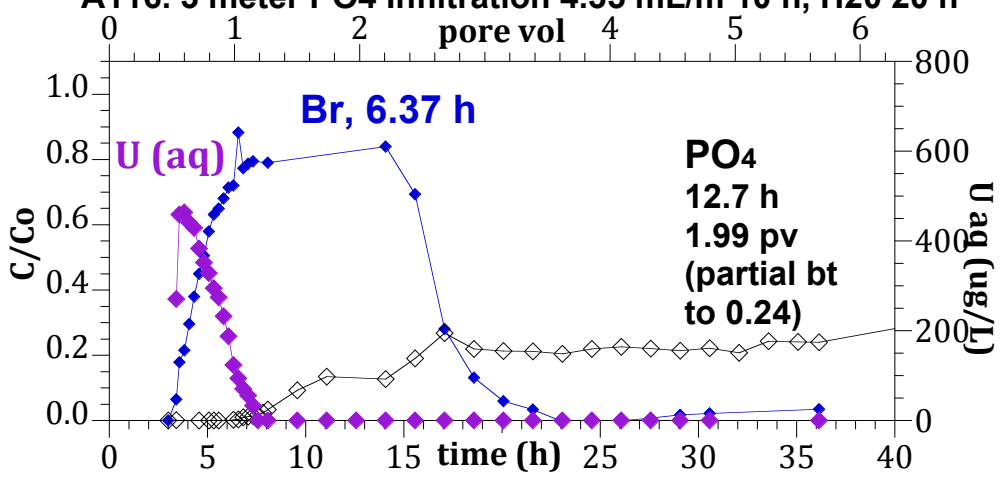

\section{D Infiltration Columns}
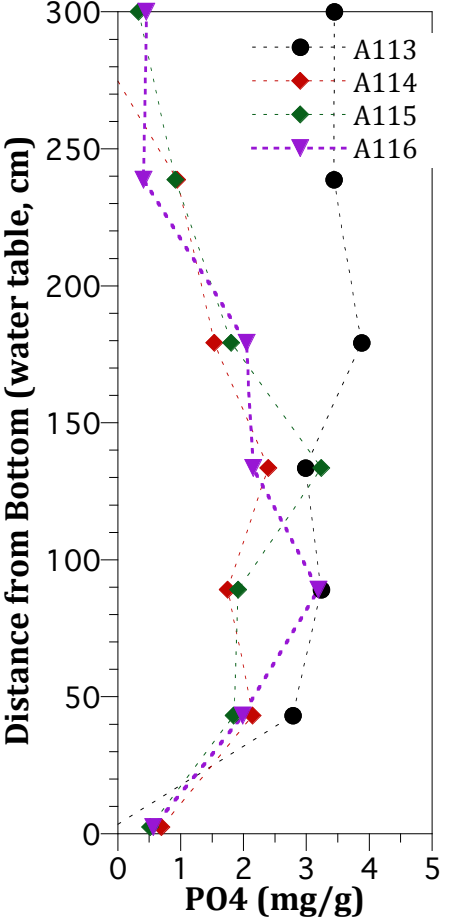


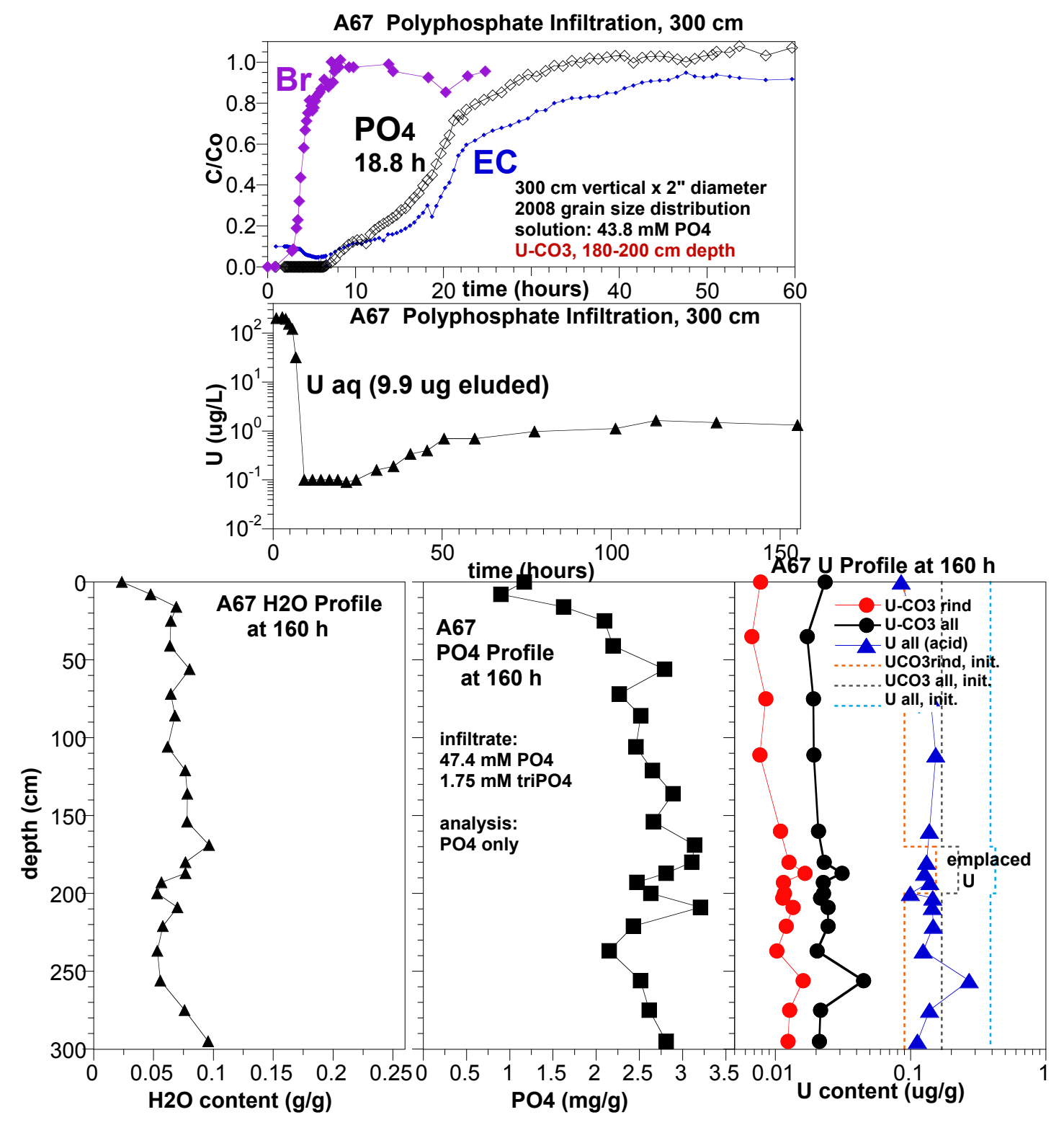



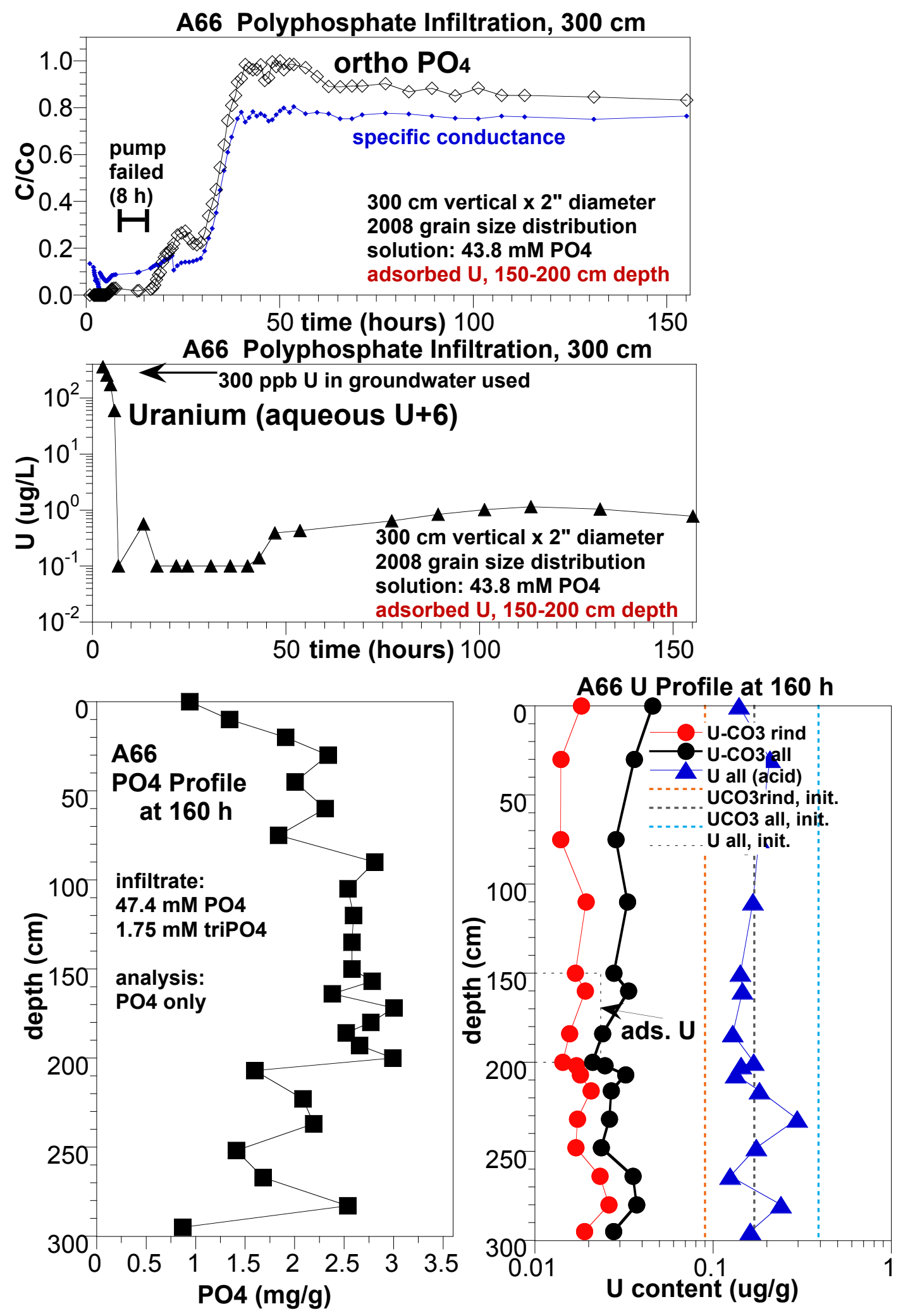

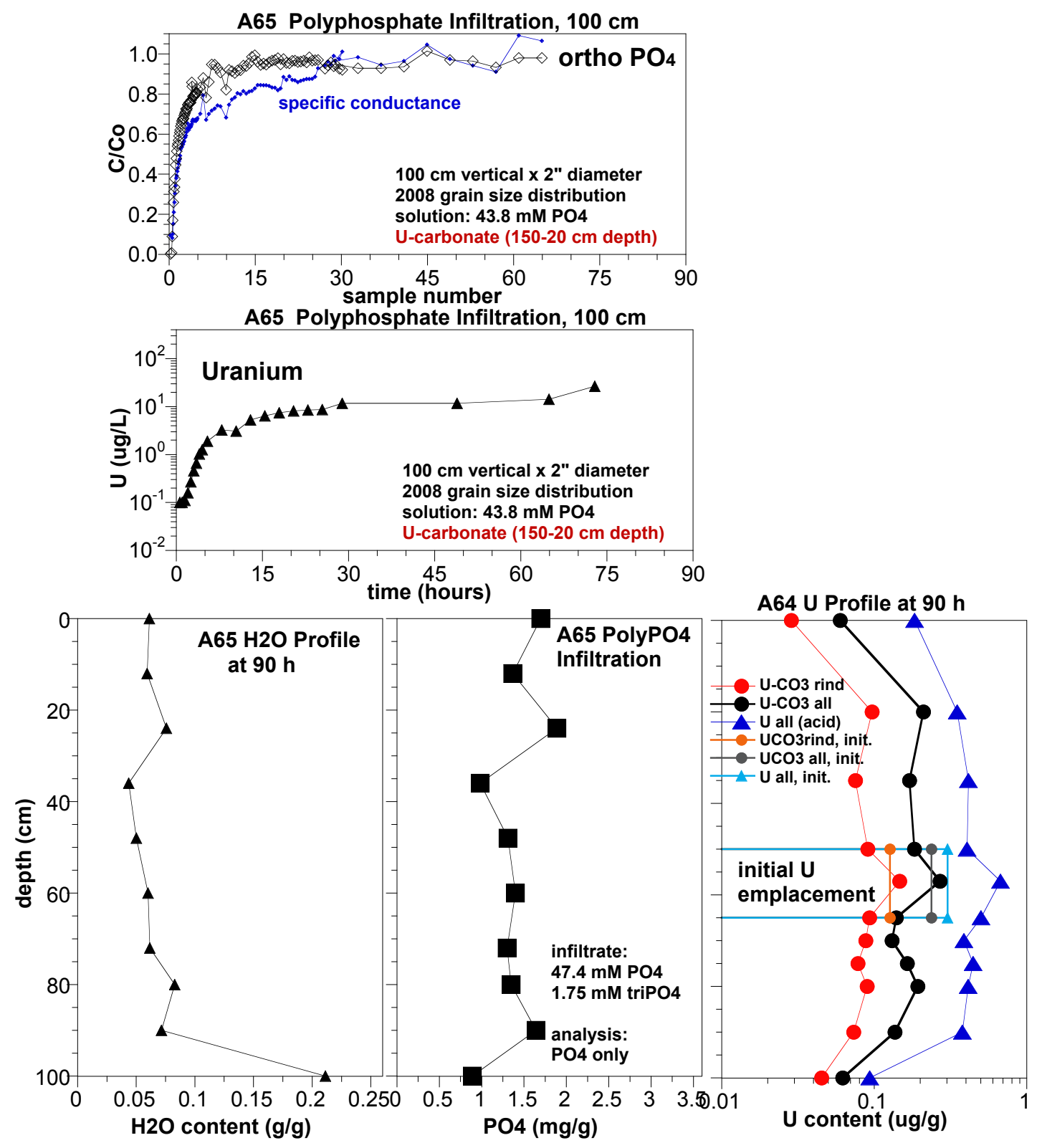

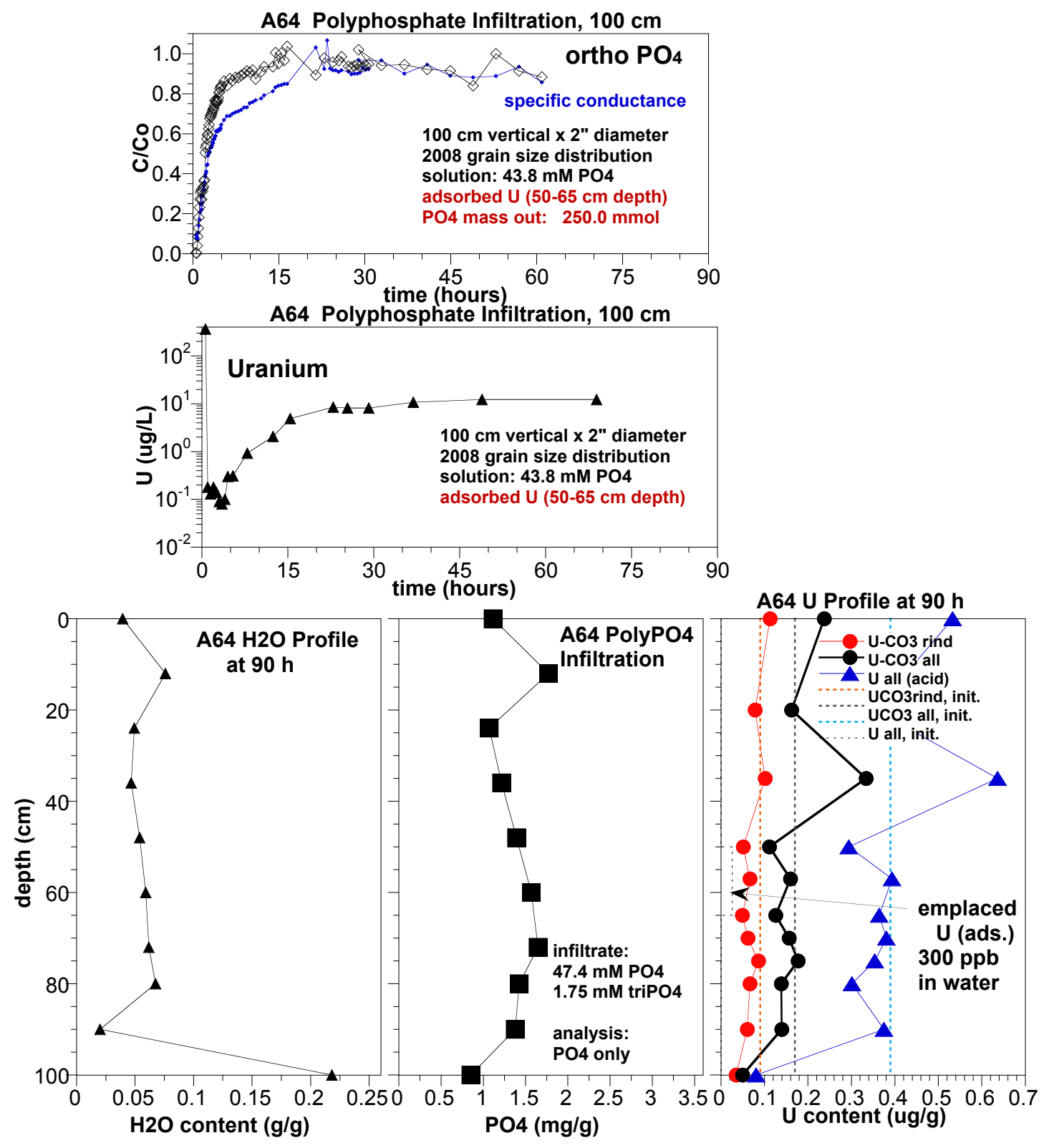

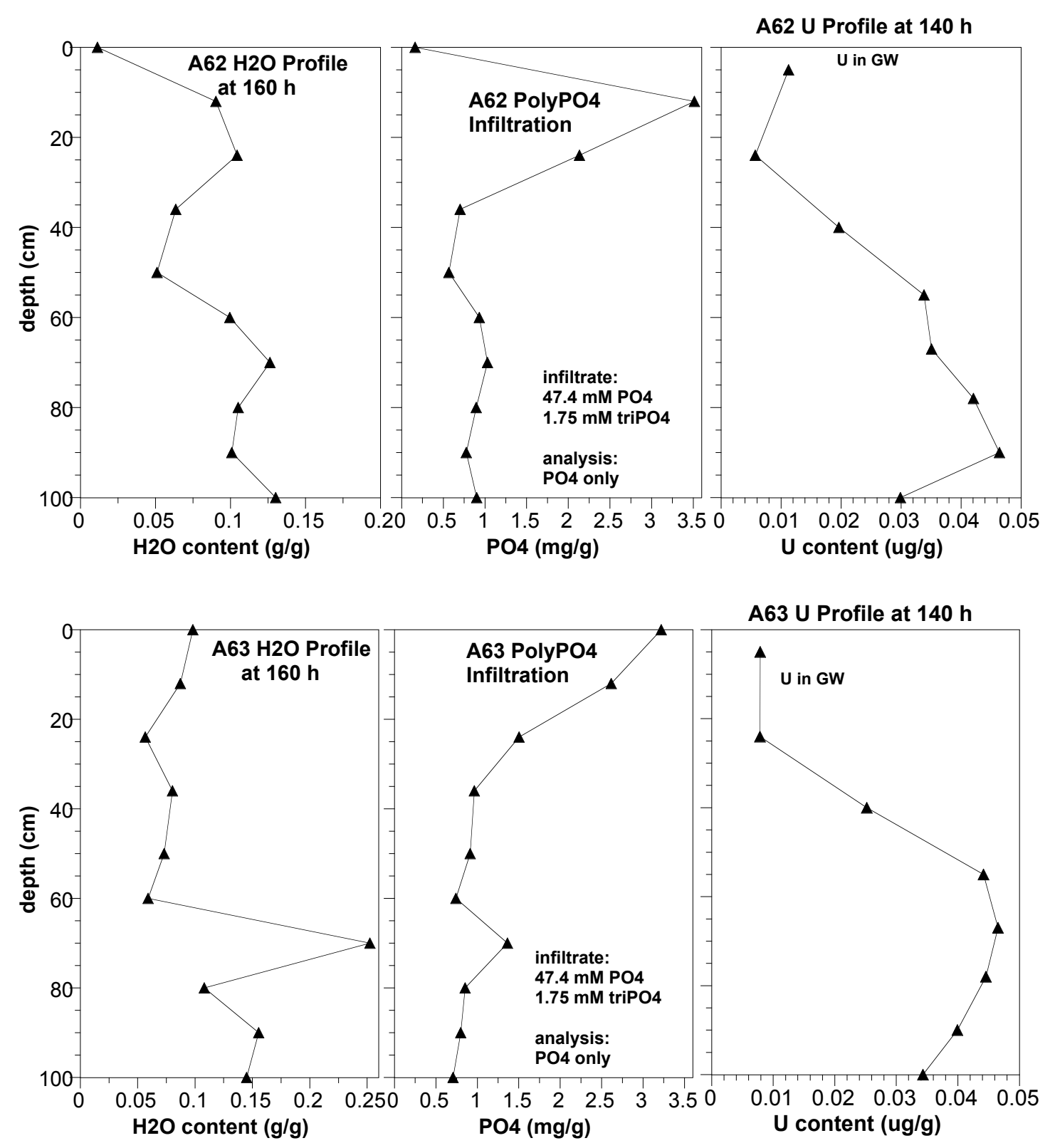


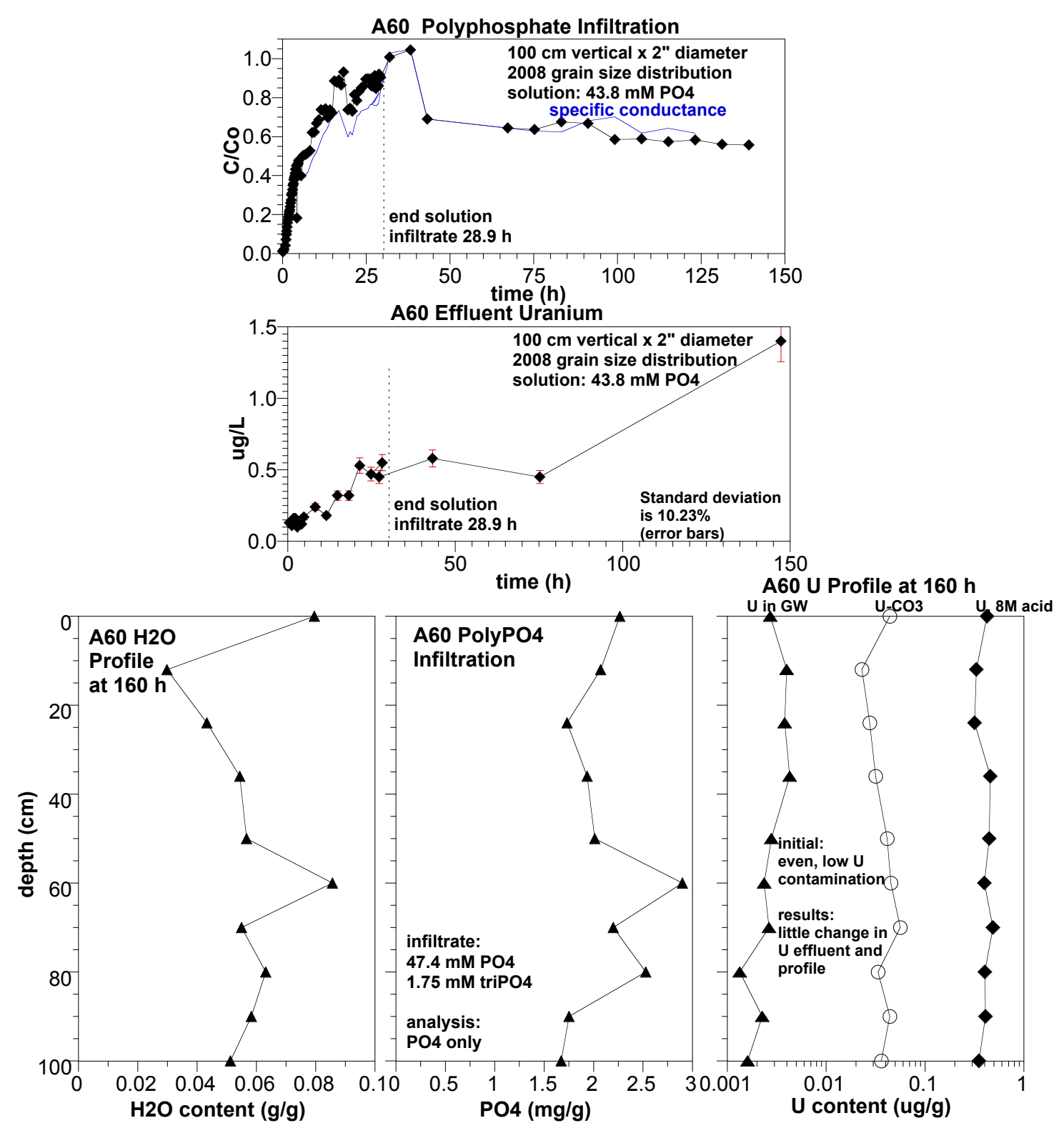


PNNL-21733

RPT-DVZ-AFRI-003

\section{Distribution}

No. of

Copies

ONSITE

18 Pacific Northwest National Laboratory

MD Freshley (2)

JS Fruchter

M Oostrom
No. of

Copies

JE Szecsody (4)

K3-61

VR Vermeul (3)

K6-96

DM Wellman (3)

K3-62

MD Williams

K6-96

JM Zachara

K8-96

K9-33

K6-96

K9-33

K3-61

Distr.1 




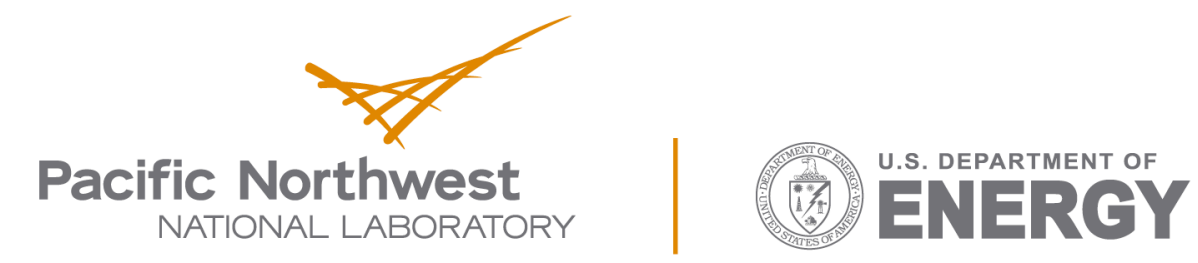

Proudly Operated by Battelle Since 1965

902 Battelle Boulevard

P.O. Box 999

Richland, WA 99352

1-888-375-PNNL (7665)

www.pnnl.gov 